Cochrane Database of Systematic Reviews

\title{
Screening for breast cancer with mammography (Review)
}

Gøtzsche PC, Jørgensen KJ

Gøtzsche PC, Jørgensen KJ.

Screening for breast cancer with mammography.

Cochrane Database of Systematic Reviews 2013, Issue 6. Art. No.: CD001877.

DOI: 10.1002/14651858.CD001877.pub5.

www.cochranelibrary.com 
TABLE OF CONTENTS

ABSTRAC

PLAIN LANGUAGE SUMMARY

BACKGROUND

OBJECTIVES

METHODS

RESULTS

DISCUSSION

AUTHORS' CONCLUSIONS

ACKNOWLEDGEMENTS

REFERENCES

CHARACTERISTICS OF STUDIES

DATA AND ANALYSES

Analysis 1.1. Comparison 1 Screening with mammography versus no screening, Outcome 1 Deaths ascribed to breast cancer, 7 years follow up.

Analysis 1.2. Comparison 1 Screening with mammography versus no screening, Outcome 2 Deaths ascribed to breast cancer, 13 years follow up.

Analysis 1.3. Comparison 1 Screening with mammography versus no screening, Outcome 3 Deaths ascribed to breast cancer, 7 years follow up, women below 50 years of age (Malmö 55).

Analysis 1.4. Comparison 1 Screening with mammography versus no screening, Outcome 4 Deaths ascribed to breast cancer, 7 years follow up, women at least 50 years of age (Malmö 55).

Analysis 1.5. Comparison 1 Screening with mammography versus no screening, Outcome 5 Deaths ascribed to breast cancer, 13 years follow up, women below 50 years of age.

Analysis 1.6. Comparison 1 Screening with mammography versus no screening, Outcome 6 Deaths ascribed to breast cancer, 13 years follow up, women at least 50 years of age.

Analysis 1.7. Comparison 1 Screening with mammography versus no screening, Outcome 7 Deaths ascribed to any cancer, all women.

Analysis 1.8. Comparison 1 Screening with mammography versus no screening, Outcome 8 Overall mortality, 7 years follow up.

Analysis 1.9. Comparison 1 Screening with mammography versus no screening, Outcome 9 Overall mortality, 13 years follow up.

Analysis 1.10. Comparison 1 Screening with mammography versus no screening, Outcome 10 Overall mortality, 7 years follow up, women below 50 years of age.

Analysis 1.11. Comparison 1 Screening with mammography versus no screening, Outcome 11 Overall mortality, 7 years follow up, women at least 50 years of age.

Analysis 1.12. Comparison 1 Screening with mammography versus no screening, Outcome 12 Overall mortality, 13 years follow up, women below 50 years of age.

Analysis 1.13. Comparison 1 Screening with mammography versus no screening, Outcome 13 Overall mortality, 13 years follow up, women at least 50 years of age.

Analysis 1.14. Comparison 1 Screening with mammography versus no screening, Outcome 14 Number of mastectomies and lumpectomies.

Analysis 1.15. Comparison 1 Screening with mammography versus no screening, Outcome 15 Number of mastectomies. ...... Analysis 1.16. Comparison 1 Screening with mammography versus no screening, Outcome 16 Number treated with radiotherapy.

Analysis 1.17. Comparison 1 Screening with mammography versus no screening, Outcome 17 Number treated with chemotherapy.

Analysis 1.18. Comparison 1 Screening with mammography versus no screening, Outcome 18 Number treated with hormone therapy.

Analysis 1.19. Comparison 1 Screening with mammography versus no screening, Outcome 19 Mortality among breast cancer patients in the Two-County study, 7 years follow up.

Analysis 1.20. Comparison 1 Screening with mammography versus no screening, Outcome 20 Results for biased trial. ...........

Analysis 1.21. Comparison 1 Screening with mammography versus no screening, Outcome 21 Number of cancers. ................ ADDITIONAL TABLES

WHAT'S NEW

HISTORY 
[Intervention Review]

\section{Screening for breast cancer with mammography}

Peter C Gøtzscheㄹ, Karsten Juhl Jørgensen ${ }^{1}$

${ }^{1}$ The Nordic Cochrane Centre, Rigshospitalet, Copenhagen, Denmark

Contact: Peter C Gøtzsche, The Nordic Cochrane Centre, Rigshospitalet, Blegdamsvej 9, 7811, Copenhagen, DK-2100, Denmark. pcg@cochrane.dk.

Editorial group: Cochrane Breast Cancer Group.

Publication status and date: Stable (no update expected for reasons given in 'What's new'), published in Issue 6, 2013.

Citation: Gøtzsche PC, Jørgensen KJ. Screening for breast cancer with mammography. Cochrane Database of Systematic Reviews 2013, Issue 6. Art. No.: CD001877. DOI: 10.1002/14651858.CD001877.pub5.

Copyright @ 2013 The Cochrane Collaboration. Published by John Wiley \& Sons, Ltd.

\section{A B S T R A C T}

\section{Background}

A variety of estimates of the benefits and harms of mammographic screening for breast cancer have been published and national policies vary.

\section{Objectives}

To assess the effect of screening for breast cancer with mammography on mortality and morbidity.

\section{Search methods}

We searched PubMed (22 November 2012) and the World Health Organization's International Clinical Trials Registry Platform (22 November 2012).

\section{Selection criteria}

Randomised trials comparing mammographic screening with no mammographic screening.

\section{Data collection and analysis}

Two authors independently extracted data. Study authors were contacted for additional information.

\section{Main results}

Eight eligible trials were identified. We excluded a trial because the randomisation had failed to produce comparable groups.The eligible trials included 600,000 women in the analyses in the age range 39 to 74 years. Three trials with adequate randomisation did not show a statistically significant reduction in breast cancer mortality at 13 years (relative risk (RR) $0.90,95 \%$ confidence interval (CI) 0.79 to 1.02 ); four trials with suboptimal randomisation showed a significant reduction in breast cancer mortality with an $\mathrm{RR}$ of $0.75(95 \% \mathrm{Cl} 0.67$ to 0.83$)$. The RR for all seven trials combined was $0.81(95 \% \mathrm{Cl} 0.74$ to 0.87$)$.

We found that breast cancer mortality was an unreliable outcome that was biased in favour of screening, mainly because of differential misclassification of cause of death. The trials with adequate randomisation did not find an effect of screening on total cancer mortality, including breast cancer, after 10 years (RR $1.02,95 \% \mathrm{Cl} 0.95$ to 1.10 ) or on all-cause mortality after 13 years (RR $0.99,95 \% \mathrm{Cl} 0.95$ to 1.03 ).

Total numbers of lumpectomies and mastectomies were significantly larger in the screened groups (RR $1.31,95 \% \mathrm{Cl} 1.22$ to 1.42 ), as were number of mastectomies (RR $1.20,95 \% \mathrm{Cl} 1.08$ to 1.32). The use of radiotherapy was similarly increased whereas there was no difference in the use of chemotherapy (data available in only two trials). 


\section{Authors' conclusions}

If we assume that screening reduces breast cancer mortality by $15 \%$ and that overdiagnosis and overtreatment is at $30 \%$, it means that for every 2000 women invited for screening throughout 10 years, one will avoid dying of breast cancer and 10 healthy women, who would not have been diagnosed if there had not been screening, will be treated unnecessarily. Furthermore, more than 200 women will experience important psychological distress including anxiety and uncertainty for years because of false positive findings. To help ensure that the women are fully informed before they decide whether or not to attend screening, we have written an evidence-based leaflet for lay people that is available in several languages on www.cochrane.dk. Because of substantial advances in treatment and greater breast cancer awareness since the trials were carried out, it is likely that the absolute effect of screening today is smaller than in the trials. Recent observational studies show more overdiagnosis than in the trials and very little or no reduction in the incidence of advanced cancers with screening.

\section{PLAIN LANGUAGE SUMMARY}

\section{Screening for breast cancer with mammography}

Screening with mammography uses X-ray imaging to find breast cancer before a lump can be felt. The goal is to treat cancer earlier, when a cure is more likely. The review includes seven trials that involved 600,000 women in the age range 39 to 74 years who were randomly assigned to receive screening mammograms or not. The studies which provided the most reliable information showed that screening did not reduce breast cancer mortality. Studies that were potentially more biased (less carefully done) found that screening reduced breast cancer mortality. However, screening will result in some women getting a cancer diagnosis even though their cancer would not have led to death or sickness. Currently, it is not possible to tell which women these are, and they are therefore likely to have breasts or lumps removed and to receive radiotherapy unnecessarily. If we assume that screening reduces breast cancer mortality by $15 \%$ after 13 years of follow-up and that overdiagnosis and overtreatment is at 30\%, it means that for every 2000 women invited for screening throughout 10 years, one will avoid dying of breast cancer and 10 healthy women, who would not have been diagnosed if there had not been screening, will be treated unnecessarily. Furthermore, more than 200 women will experience important psychological distress including anxiety and uncertainty for years because of false positive findings.

Women invited to screening should be fully informed of both the benefits and harms. To help ensure that the requirements for informed choice for women contemplating whether or not to attend a screening programme can be met, we have written an evidence-based leaflet for lay people that is available in several languages on www.cochrane.dk. Because of substantial advances in treatment and greater breast cancer awareness since the trials were carried out, it is likely that the absolute effect of screening today is smaller than in the trials. Recent observational studies show more overdiagnosis than in the trials and very little or no reduction in the incidence of advanced cancers with screening. 


\section{B A C K G R O U N D}

Breast cancer is an important cause of death among women. Early detection through mass screening with mammography has the potential to reduce mortality, but it also leads to overdiagnosis and overtreatment (IARC 2002). Since screening preferentially identifies slow-growing tumours (length bias) (Final reports 1977; Fox 1979), the harms of unnecessary treatment of overdiagnosed tumours could reduce or outweigh any potential benefits.

The best way to reliably estimate the effectiveness of screening is with randomised trials. Large trials, involving 650,000 women, have been carried out in North America and Europe (Canada 1980; Edinburgh 1978; Göteborg 1982; Malmö 1976; New York 1963; Stockholm 1981; Two-County 1977; UK age trial 1991), and several systematic reviews and meta-analyses have been published (Berry 1998; Blamey 2000; Cox 1997; Demissie 1998; Elwood 1993; Glasziou 1992; Glasziou 1995; Glasziou 1997; Gøtzsche 2000; Gøtzsche 2011; Hendrick 1997; Humphrey 2002; IARC 2002; Kerlikowske 1995; Kerlikowske 1997; Larsson 1996; Larsson 1997; Nelson 2009; Nyström 1993; Nyström 1996; Nyström 1997; Nyström 2000; Nyström 2002; Olsen 2001a; Olsen 2001b; Smart 1995; Swed Cancer Soc 1996; UK review 2012; Wald 1993).

The large number of reviews reflects the controversies surrounding mammography screening and the uncertainties of its effects in women of various ages. There is wide variation in screening policies between different countries, with some countries abstaining from introducing screening partly because of the lack of a documented reduction in all-cause mortality (Isacsson 1985; Skrabanek 1993; Swift 1993). One area of concern is the potential for radiotherapy treatment of low-risk women, such as those who have their cancers identified at screening, to increase all-cause mortality because of adverse cardiovascular effects (EBCTCG 1995; EBCTCG 2000). In addition, there is concern that cause of death has not been ascribed in an unbiased fashion in the trials. Finally, carcinoma in situ is much more likely to be detected with screening mammography and although less than half of the cases will progress to be invasive (Nielsen 1987; Welch 1997) these women will nevertheless be treated with surgery, drugs and radiotherapy.

Meta-analyses of screening are often deficient (Walter 1999) and few of the meta-analyses listed above have taken account of the risk of bias in the individual trials or considered harms as well as benefits. We have identified important weaknesses in the trials (Gøtzsche 2000; Gøtzsche 2000a; Gøtzsche 2004; Gøtzsche 2011) and have now updated our Cochrane Review with additional data.

\section{OB JECTIVES}

To study the effect of screening for breast cancer with mammography on mortality and morbidity.

\section{ME T HO D S}

\section{Criteria for considering studies for this review}

\section{Types of studies}

Randomised clinical trials. Trials using less reliable randomisation methods were evaluated separately.
We have discussed recent observational studies in this review as these have provided important new knowledge, e.g. in relation to evidence on overdiagnosis and other harms of screening.

\section{Types of participants}

Women without previously diagnosed breast cancer.

\section{Types of interventions}

Experimental: screening with mammography

Control: no screening with mammography

\section{Types of outcome measures}

Mortality from breast cancer

Mortality from any cancer

All-cause mortality

Use of surgical interventions

Use of adjuvant therapy

Harms of mammography

\section{Search methods for identification of studies}

We used a very broad search strategy. We searched PubMed with (breast neoplasms[MeSH] OR "breast cancer" OR mammography[MeSH] OR mammograph*) AND (mass screening $[\mathrm{MeSH}]$ OR screen*). This search was supplemented with a search on author names in the author field (Alexander $F^{\star}$, Andersson $\mathrm{I}^{\star}$, Baines $\mathrm{C}^{\star}$, Bjurstam $\mathrm{N}^{\star}$, Duffy $\mathrm{S}^{\star}$, Fagerberg $\mathrm{G}^{\star}$, Frisell $J^{\star}$, Miller $A B$, Moss $S^{\star}$, Nystrom $L^{\star}$, Shapiro $S$, Tabar $L^{\star}$ ). The latest search was done on 22 November 2012 and 29,222 records were imported into ProCite. Until the 2009 review, these records were searched for author names, cities and eponyms for the trials; thereafter, all new records were browsed. This very broad search strategy, combined with browsing the titles and reading the abstracts when a paper might be relevant for mammography screening, enabled us to assemble also the observational studies of the benefits and harms of screening.

We searched the World Health Organization's International Clinical Trials Registry Platform (22 November 2012) with this strategy, for Recruitment Status ALL: (Condition: breast AND (cancer\% OR carcinoma\% OR neoplas\% OR tumour\% OR tumor\%) AND Intervention: screen OR mass screen\%) OR (Condition: breast AND (cancer\% OR carcinoma\% OR neoplas\% OR tumour\% OR tumor\%) AND Intervention: mammograph\%) OR (Condition: breast neoplasm AND Intervention: mammography).

We scanned reference lists and included letters, abstracts, grey literature and unpublished data to retrieve as much relevant information as possible. There were no language restrictions.

\section{Data collection and analysis}

Two authors independently decided which trials to include based on the prestated criteria. Disagreements were resolved by discussion.

We assessed whether the randomisation was adequate and led to comparable groups, following standard criteria as closely as possible (Higgins 2008). We divided the trials into those with adequate randomisation and those with suboptimal randomisation. 
Two authors independently extracted methodological and outcome data; disagreements were resolved by discussion. Extracted data included: number of women randomised randomisation and blinding procedures; exclusions after randomisation; type of mammography; number of screenings and interval between screenings; attendance rate; introduction of screening in the control group; co-interventions; number of cancers identified; breast cancer mortality; cancer mortality; allcause mortality; harms of mammography; and use of surgical interventions, chemotherapy, radiotherapy, tamoxifen and other adjuvant therapy. We contacted the primary investigators to clarify uncertainties.

\section{Statistical methods}

We performed intention-to-treat analyses, when possible, by including all randomised women. A fixed-effect model with the Mantel-Haenszel method was used, and 95\% confidence intervals (CI) are presented. In case of heterogeneity in the trial results $(\mathrm{P}<$ 0.10 ), we explored possible causes. We present the analyses in the graphs as risk ratios, for convenience, but also discuss the absolute risk reductions (or increases) and risk differences as these are more important than relative risks for trials in low-risk populations with few events, such as in the trials we reviewed.

In the trials with suboptimal randomisation, we could not carry out a proper analysis for all-cause mortality as we did not have access to the necessary data (see 'Risk of bias in included studies') but present the available data in the graphs for the sake of completeness. For breast cancer mortality, our estimates are not formally correct because we were unable to adjust for baseline differences. However, they turned out to be in close agreement with the estimates and $\mathrm{Cls}$ published by the trialists. For completeness, we have shown the pooled estimates for the trials with adequate randomisation and those with suboptimal randomisation together, although we believe these summary estimates are likely to be unreliable (see below).

We report outcome data at approximately 7 and 13 years, which were the most common follow-up periods in the trial reports; and present age groups under 50 years of age and above, which is the age limit that has most often been used by the trialists and in screening programmes.

\section{RE S U L T S}

\section{Description of studies}

We identified 11 completed trials. From these we excluded two small trials of several interventions including mammography (Berglund 2000; Dales 1979) and a trial involving 166,600 women where the only intervention was a prevalence screen and where exclusions after randomisation occurred only in the screened group; previous cancer at any site was an exclusion criterion and more than 1500 women were excluded from the screened group, 468 because they had already died (Singapore 1994).

An additional trial in the UK is ongoing (http://www.controlledtrials.com/ISRCTN33292440). This is an age extension cluster randomised trial, recruiting women aged 47-49 or 71-73 years old, and aiming for a sample size of 3 million women. It started in 2010 and is expected to run till the end of 2026 .
Some of the eight eligible trials (Canada 1980; Edinburgh 1978; Göteborg 1982; Malmö 1976; New York 1963; Stockholm 1981; Two-County 1977; UK age trial 1991) comprised slightly different subtrials. The Canadian trial was actually two trials, one covering the age group 40 to 49 years (Canada 1980a) and the other 50 to 59 years (Canada 1980b). The Edinburgh and Malmö trials continued to include women as they passed the lower age limit for entry to the trial, and the Two-County trial had different randomisation ratios in the two counties (Kopparberg 1977; Östergötland 1978). Most trials covered the age range 45 to 64 years, but the UK age trial invited women aged 39 to 41 years to participate. The Canadian trial was the only one in which the women were individually randomised after invitation and gave informed consent; the others used a variety of procedures based on a prespecified segment of the female population that was randomised to invitation for screening or to a control group.

The number of consecutive screening invitations was in the range of four to nine for all trials except the Stockholm and Two-County trials, in which a large fraction were invited for only two or three screenings. In the Two-County trial, the mammographically screened women were encouraged to perform breast self-examinations once a month on a fixed date (Rapport 1982). This was Swedish policy generally but we do not know for certain whether this was also true for the Göteborg, Malmö and Stockholm trials. Clinical examinations of screened women were performed in New York and Edinburgh. In Canada, in the 40 to 49 year age group, screened women had an annual clinical breast examination whereas control women were examined at the first visit and were taught self-examination for use thereafter. In the 50 to 59 year age group, all women had their breasts clinically examined annually.

The women in the control group were not invited to screening at any point in time in the New York trial, whereas they were invited for screening after 10 to 13 years of follow up in the Edinburgh, Malmö and UK age trials. In the Canadian trial, most of the women in the control group were invited when the trial ended (Baines 2005). Some women were invited for screening while the trial was still ongoing in the Göteborg, Stockholm and Two-County trials (see 'Risk of bias in included studies').

In all trials, women in the control groups were offered usual care. This included mammography on indication, that is for suspected malignancy, with the probable exceptions of the New York trial and the first five years of the Two-County trial.

According to the information we identified, the technical quality of the mammograms and the observer variation was assessed only in the Canadian trial. There are data on diagnostic rates, however, that show that the sensitivity in the trials that followed the New York trial has not consistently improved (Fletcher 1993; IARC 2002). Various combinations of one- and two-view mammography were used (see 'Characteristics of included studies').

\section{Risk of bias in included studies}

The trials have been conducted and reported over a long period of time, during which standards for reporting trials have improved. The New York trial, for example, was first reported in 1966 but crucial details on the randomisation method, exclusions and blinding were not published until 20 years later (Aron 1986; Shapiro 1985; Shapiro 1988). Data on use of radiotherapy and 
chemotherapy in the Kopparberg trial were published 14 years after the main results (Tabar 1999). Below we discuss the trial methodology in detail, which is essential reading to understand the controversies surrounding the effects of screening and the often conflicting information presented. The trials are described consecutively by start date.

\section{The New York trial (New York 1963)}

\section{Population studied}

The New York trial (also called the Health Insurance Plan (HIP) trial) invited women who were members of an insurance plan and aged 40 to 64 years from December 1963 to June 1966. It reported an individual randomisation within pairs matched by age, family size and employment group (Shapiro 1985). It is not clear whether the randomisation method was adequate; it was described as "alternation" by researchers who contacted one of the trial investigators (Freedman 2004). The entry date for a woman was the date she was scheduled for the examination (Shapiro 1966); the matched control was assigned the same date (Shapiro 1985). The matched pairs method should lead to intervention and control groups of exactly the same size. This is supported by the approximate numbers given in several publications, for example "The women were carefully chosen as 31,000 matched pairs" (Strax 1973). The largest published exact number of women invited is 31,092 (Fink 1972).

\section{Comparability of groups}

Postrandomisation exclusions of women with previous breast cancer occurred but this status "was most completely ascertained for screened women," whereas women in the control group "were identified through other sources as having had breast cancer diagnosed before their entry dates" (Shapiro 1988). Using information in the trial reports (Fink 1972; Shapiro 1985; Shapiro 1994), we calculated that 853 (31,092 minus 30,239) women were excluded from the screened group because of previous breast cancer compared with only $336(31,092$ minus 30,756$)$ in the control group. Although it was reported that great care was taken to identify these women, the lead investigator noted that more than 20 years after the trial started some prior breast cancer cases among the controls were unknown to the investigators and those women should have been excluded (Shapiro 1985a). This creates a bias in favour of screening for all-cause mortality and likely also for breast cancer mortality though the authors have written, without providing data, that ascertainment of cases of previous breast cancer was "nearly perfect" in those women who died from breast cancer (Shapiro 1988).

It is difficult to evaluate whether there were other baseline differences between the groups. In one paper (Shapiro 1972) the text described all randomised women and referred to a table that showed baseline differences as percentages but did not provide the numbers upon which the percentages were based. Footnotes explained that some of the data were based on $10 \%$ and $20 \%$ samples. The table title referred to women entering the trial in 1964, and not all women as claimed in the text. Assuming that the table title is correct, the data presented in some cases were a 1964 subgroup of $10 \%$ and $20 \%$ samples. These resulting samples are therefore too small to study other possible baseline differences than those related to differential exclusion of women with previous breast cancer.

\section{Assignment of cause of death}

We found no data on the autopsy rate. Assignment of cause of death was unblinded for $72 \%$ of the women with breast cancer (Shapiro 1988). The differential exclusions and unblinded assessments make us question the reliability of the reported breast cancer mortality rates.

\section{Likelihood of selection bias}

We classified the trial as suboptimally randomised.

\section{The Malmö trial (Malmö 1976)}

\section{Population studied}

This trial recruited women aged 45 to 69 years. Randomisation was carried out by computer within each birth year cohort (Andersson 1981), dividing a randomly arranged list in the middle (Andersson 1999a). The first publications noted that 21,242 women were randomised to the screening group and 21,240 to the control group (Andersson 1980; Andersson 1981a).

\section{Comparability of groups}

A later publication reported four more women in the control group (Andersson 1983) but the main publication (Andersson 1988) reported only 21,088 women in the study group and 21,195 in the control group. It did not account for the 199 or 203 missing women. The number of missing women was largest in the 45 to 50 years age group ( 137 from the intervention group and 26 or 27 from the control group), mainly because the 1929 birth year cohort was recruited by an independent research project that included mammography (Andersson 2001). The trialists recruited less than the planned $50 \%$ of this birth year cohort, but this does not explain why 26 or 27 women were missing from the control group. Exclusion of the 1929 birth year cohort from analysis changes the relative risk for death from breast cancer by only 0.01 (Andersson 2001). For 17 of the 25 birth year cohorts, the size of the study and control groups were identical or differed by only one, as expected. The largest difference in the other eight cohorts, apart from the 1929 one, was 25 fewer women than expected in the study group for the 1921 cohort (Nyström 2002). Thus, the authors of a meta-analysis of the Swedish trials did not report on all randomised women in Malmö (Nyström 2002).

The date of entry into the trial was defined differently for the two groups. For the mammography group it was the date of invitation (Andersson 1988), and the midpoint of these dates for each birth year cohort defined the date of entry for women in the control group (Andersson 2000). Enrolment began in October 1976 (Andersson 2000) and ended in September 1978 (Andersson 1988). It is not clear whether screening of the control group began in December 1990 (Nyström 2000) or in October 1992 (Nyström 2002). Most women in the control group were never screened (Nyström 2002). We calculated the interval between when screening started in the study group and in the control group (the intervention contrast) to be 19 years (Nyström 2002). In the meta-analyses of the Swedish trials, breast cancer cases diagnosed before randomisation were explicitly excluded, further reducing the screened group by 393 and the control group by 412 (Nyström 1993); in total 86 more women were excluded from the screened group than the control group. Baseline data on age were not 
significantly different in the screened group and the control group (Gøtzsche 2000a).

\section{Assignment of cause of death}

The autopsy rate for breast cancer cases as presented in the main publication for this trial (Andersson 1988) was high at 76\%, but it was halved from 1985 to 1997 (Andersson 2000). Cause-of-death assessments were blinded up to 1988 (Andersson 2000).

\section{Likelihood of selection bias}

We classified the trial as adequately randomised.

The Malmö II trial (Malmö II 1978)

\section{Population studied}

This was an extension of the Malmö trial, called MMST II. Women who reached the age of 45 years were enrolled between September 1978 and November 1990; screening of the control group began in September 1991 (Nyström 2000). The long enrolment period gives an average estimated intervention contrast of eight years. Although the entry criterion for age was stated to be 45 years, the trialists included 6780 women aged 40 to 44 (Nyström 2002).

\section{Comparability of groups}

The MMST II trial has been published only in brief (Andersson 1997). We therefore cannot check whether there were differential postrandomisation exclusions. If the same procedure as in the Malmö trial had been followed, the sizes of the study and control group cohorts should not differ by more than one. However, the group size differed more for seven of the 13 birth year cohorts (Nyström 2002). The reported numbers in the individual cohorts do not add up to the reported totals, but to 28 fewer in the study group and 28 more in the control group. Because of an administrative error, the entire 1934 birth year cohort was invited for screening (Andersson 1999b). If this cohort is excluded, there is still a gross imbalance with 5724 women in the study group and only 5289 in the control group, for those aged 45 to 49 years $(P=0.00004$, Poisson analysis). In total, there were 9581 and 8212 women in the analyses, respectively (Nyström 2002).

This trial was neither included nor mentioned in the 1993 meta-analysis of the Swedish trials (Nyström 1993). The lead investigator informed us that it was not conducted according to a formal protocol (Andersson 1999b), whereas the most recent meta-analysis reported that the trial was conducted with the same protocol as the older part of the trial (Nyström 2002). When the breast cancer mortality rate in the screening group is plotted against the control group rate for eight trials, with data from younger women, the Malmö II trial is a clear outlier (Berry 1998).

Assignment of cause of death

An official registry was used for cause-of-death assessments.

\section{Likelihood of selection bias}

We classified the trial as suboptimally randomised.

The Two-County trial (Kopparberg 1977; Two-County 1977; Östergötland 1978)

\section{Population studied}

This trial recruited women 40 years of age and over in Kopparberg and Östergötland; the two subtrials were age-matched and cluster randomised ( 21 and 24 clusters, respectively). The selection of clusters was stratified to ensure an even distribution between the two groups with respect to residency (urban or rural), socioeconomic factors and size (Kopparberg 1977; Tabar 1979; Östergötland 1978). The randomisation process and the definition of the date of entry have been inconsistently described; and some women were only 38 years of age, below the inclusion criterion (Nyström 2002). According to the first publications, random allocation of the women in each community block took place three to four weeks before screening started (Fagerberg 1985); all women from a given block entered the trial at the same time and this date was the date of randomisation (Tabar 1985). However, it has also been described that a public notary allocated the clusters in Östergötland by tossing a coin (Nyström 2000) while witnesses were present (Fagerberg, personal communication, 1999). We have been unable to find any detailed description of the randomisation in Kopparberg but found a recent description for the whole trial: "Randomisation was by traditional mechanical methods and took place under the supervision of the trial statistician" (Duffy 2003). Thus it is not clear whether the randomisation was carried out on one occasion or whether it took place over several years.

Women were invited to their first screening from October 1977 to January 1980 in Kopparberg (Tabar 1981). The cohorts in Östergötland were defined between May 1978 and March 1981. It is not clear how many women were randomised and reported numbers vary considerably, both for numbers randomised (Table 1) and for numbers of breast cancer deaths, despite similar follow up (Gøtzsche 2004). Documentation of baseline comparability was called for in 1988 (Andersson 1988a) but it appears not to have been published. Since the randomisation was stratified after socioeconomic factors (Tabar 1991), baseline data potentially affecting mortality should exist.

\section{Comparability of groups}

The randomisation procedure seems to have led to noncomparable groups. First, breast cancer mortality in the control group was almost twice as high in Kopparberg compared to Östergötland $(0.0021$ versus $0.0012, P=0.02)$. This was not apparent from the tabulated data (Tabar 1985). The published graphs are also potentially misleading; although adjacent mortality curves look much the same the two y-axes are differently scaled (Tabar 1995). Second, in Kopparberg more women in the control group were diagnosed with breast cancer before entry to the trial than in the study group. How the diagnostic information was obtained was not described (Tabar 1989) and the number of women excluded for this reason was not stated, but can be calculated by comparing two tables (Tabar 1985; Tabar 1989). More women were excluded from the control group than from the study group $(P=0.03)$; most of the imbalance occurred in the age group 60 to 69 years $(P=0.007)$. In Östergötland, numbers of exclusions were very similar, $1.40 \%$ versus 1.39\%. Third, age-matching was reported (Tabar 1979; Tabar 1981; Tabar 1985a) but study group women were on average five months older (Nixon 2000), which is a small bias against screening.

We were unable to ascertain when systematic screening of the control group started. The available information is conflicting and the range of the discrepancies amounts to three years for both 
counties (Arnesson 1995; Duffy 2003; Nyström 1993, ; Nyström 2000; Nyström 2002; Rapport 1982; Tabar 1979; Tabar 1985; Tabar 1992). It seems most likely that screening of the control group in Kopparberg started in 1982, in accordance with the trial protocol (Rapport 1982) and a doctoral thesis (Nyström 2000). In this case, the impression conveyed in the main publication for the trial that screening was offered to the control group after publication of the results in April 1985 is incorrect (Tabar 1985; Tabar 1992). In the protocol, a fiveyear intervention period was planned but with a stopping rule based on statistical significance testing every six months (Rapport 1982). The trial publications did not mention the repeated looks at the data (Tabar 1985). We estimated an intervention contrast of five years for Kopparberg and eight years for Östergötland. A valid comparison of benefits and harms of screening should be confined to the period prior to screening of the control group.

No information is available from the primary author of this trial (Atterstam 1999; Prorok 2000; Tabar 2000a). We have not received information from Nyström either on the missing account of the randomisation process in Kopparberg, or from the Swedish National Board of Health (Socialstyrelsen), which funded the trial.

\section{Assignment of cause of death}

The autopsy rate was 36\% (Projektgruppen 1985). According to an investigator involved with the trial (Crewdson 2002), other Swedish trialists (Nyström 2002), and an IARC report (IARC 2002), causeof-death assessments were not blind. This has been disputed by the lead investigator of the trial (Tabar 2002). In a meta-analysis of the Swedish trials, a blinded independent endpoint committee reassessed the death classifications (Nyström 1993).

\section{Likelihood of selection bias}

We classified the trial as suboptimally randomised and likely to be biased.

\section{The Edinburgh trial (Edinburgh 1978)}

\section{Population studied}

This trial used cluster randomisation with about 87 clusters (the number varies in different reports); the age group was 45 to 64 years. Coded general practices were stratified by size and allocated by manual application of random numbers. In one district, at least three of the 15 practices initially randomised to the screening group later changed allocation status, and at least four others were added (Alexander 1989). Two of these practices were unintentionally told the wrong group, and three changed allocation group because of "statistical considerations" (Roberts 1984). One practice was included in the follow up even though it was a pilot screening practice that did not participate in the randomisation (Roberts 1990). The trialists have conducted replicate analyses with these women removed (Alexander 2000) but as far as we know the data have not been published.

\section{Comparability of groups}

Doubts about the randomisation process were raised by the trialists (Alexander 1989), supported by baseline differences: $26 \%$ of the women in the control group and $53 \%$ in the study group belonged to the highest socioeconomic level (Alexander 1994), and mammographic screening was associated with an unlikely $26 \%$ reduction in cardiovascular mortality (Alexander 1989). Entry dates were defined differently. In most practices the entry date was the date the invitation letter was issued; for women in hospital it was the date their names appeared on a list sent to their general practitioner. The entry date for five practices was not defined. In the control group, the entry date was the date the physician's practice was indexed. Before entry, the general practitioners in the screening practices had to decide whether each woman would be suitable for invitation to screening. Physicians in the control practices decided whether each woman would be eligible to receive a leaflet about breast self-examination (Roberts 1984). The eligibility criteria were thus broader for the control group and the entry dates seem to be earlier. Practices were enrolled one at a time over a period of 2.5 years, from 1979 to 1981 (Alexander 1989). Women turning 45 years of age and women moving into the city were enrolled on an ongoing basis (Roberts 1984). Recruitment of the control group began in the 10th year of follow up (Alexander 1994). The exclusion procedures were different in the study and control groups (Chamberlain 1981; Roberts 1984) and 338 versus 177 women were excluded because of prior breast cancer (Alexander 1994).

\section{Likelihood of selection bias}

This trial was not adequately randomised and was so biased that it cannot provide reliable data. We have therefore shown its results in a separate graph, for completeness only.

The Canadian trial (Canada 1980; Canada 1980a; Canada 1980b)

\section{Population studied}

Women aged 40 to 59 years were individually randomised after invitation and giving informed consent. Their names were entered successively on allocation lists, where the intervention was prespecified on each line. An independent review of ways in which the randomisation could have been subverted uncovered no evidence of this (Bailar 1997). Enrolment took place from January 1980 to March 1985 (Canada 1980a).

\section{Comparability of groups}

Fifty-nine women in the age group 40 to 49 years and 54 in the age group 50 to 59 years were excluded after randomisation (Miller 2000; Miller 2002); none were excluded because of previous breast cancer. The comparison groups were nearly identical in size $(25,214$ versus 25,216 aged 40 to 49 years; and 19,711 versus 19,694 aged 50 to 59 years), and were similar at baseline for age and nine other factors of potential prognostic importance (Baines 1994; Canada 1980; Canada 1980a; Canada 1980b; Miller 2000; Miller 2002). There were more small node-positive cancers at baseline in the screened group than in the control group among women aged 40 to 49 years, but this is a post-hoc subgroup finding which is probably a result of the intervention (Baines 1995; Baines 1997; Canada 1980). Several women with positive nodes were probably unrecognised in the control group (Miller 1997a). This is supported by the fact that $47 \%$ of women with node-negative cancer in the usual care group died of breast cancer compared with $28 \%$ in the mammography group (Miller 1997). Exclusion of the deaths caused by these cancers did not change the result (Baines 1995; Baines 1997; Canada 1980).

\section{Assignment of cause of death}

The autopsy rate was low, 6\% (Baines 2001). Cause-of-death assessments were blinded for women with diagnosed breast cancer 
and for other possible breast cancer deaths, for follow up after seven years. For follow up after 13 years, death certificates were used in a minority of cases as some hospitals refused to release clinical records (Miller 2000; Miller 2002).

\section{Likelihood of selection bias}

We classified the trial as adequately randomised.

\section{The Stockholm trial (Stockholm 1981)}

\section{Population studied}

In this trial, women were invited for screening if they were aged 40 to 64 years in 1981 (born 1917 to 1941) and were born on days 1 to10 in a month, or if they were aged 40 to 64 years in 1982 (born 1918 to 1942) and were born on days 21 to 30 in a month (Frisell 1986). Similarly, there were two groups of controls but since they were all born on days 11 to 20 in a month, most women served as controls twice (those born in 1918 to 1941). Invitations were sent successively by ascending order of birth date (Frisell 1989). The date of entry was the date of invitation (Frisell 1991). Enrolment of the first cohort began in March 1981 and ended in April 1982; enrolment of the second cohort began in April 1982 and ended in May 1983 (Frisell 2000a).

\section{Comparability of groups}

Since the control women born in 1918 to 1941 served as controls for both subtrials (Frisell 1989a; Frisell 2000b) they should have two entry dates, approximately one year apart, but this was not described. According to the matching there should have been a similar number of women in the screened and control groups in each subtrial, but we found an imbalance in the second subtrial $(P=0.01$, Poisson analysis) with 508 more women belonging to the screened group than to the control group (Frisell 1991). Furthermore, in the time period where 19,507 women born from 1918 to 1942 were invited to screening, only 929 women, all born in 1942, were included in the control group (Nyström 2002).

The reported numbers of women in the various subgroups are inconsistent, as are the numbers reported to us in personal communications (Frisell 2000a; Frisell 2000b). Because of the problems related to timing and the overlap of the two control groups, results from the two subtrials were not independent, and the estimates cannot be pooled without correction for dependence. It is not clear how these difficulties were handled in the trialists' analysis (Frisell 1991) or in the Swedish meta-analyses (Nyström 1993; Nyström 2000; Nyström 2002).

The first trial report did not describe any women excluded after randomisation; only breast cancer cases identified during the intervention period were followed up to ascertain breast cancer deaths (Frisell 1991). Exclusions occurred in later publications but no numbers were given (Frisell 1997; Nyström 1993; Nyström 2000) and the numbers we have received in personal communications have been inconsistent (Frisell 2000a; Frisell 2000b).

Of those attending the first screening, $25 \%$ had had a mammogram in the two previous years (Frisell 1989a). Information on screening of the control group varied. A meta-analysis noted that a few women were screened after three years and most after four years (Nyström 1993), a doctoral thesis stated that the controls were invited for screening from October 1985 (Nyström 2000), and the trialists noted that they were invited during 1986 (Frisell 1989a; Frisell 1991). We estimated an intervention contrast of four years. A valid comparison of benefits and harms of screening should be restricted to this period (Frisell 1991).

\section{Assignment of cause of death}

It is not stated whether cause-of-death assessments were blinded for this initial period. The autopsy rate was 22\% (Nyström 2000).

\section{Likelihood of selection bias}

We classified the trial as suboptimally randomised.

\section{The Göteborg trial (Göteborg 1982)}

\section{Population studied}

This trial included women aged 39 to 59 years. Birth year cohorts were randomised by the city municipality's computer department with the ratio between study group and control group adjusted according to the capacity of the screening unit (Bjurstam 2000; Nyström 2002). The randomisation was by cluster based on date of birth in the 1923 to 1935 cohorts, and by individual birth date for the 1936 to 1944 cohorts (Bjurstam 1997).

\section{Comparability of groups}

We found baseline data only on age, and only for those aged 39 to 49 years. Since the allocation ratios were irregular, we could not assess the comparability of groups and adequacy of randomisation. The randomisation ratios were most extreme for the oldest and the youngest birth-year cohorts randomised in clusters; for 1923, there were 2.0 times as many women in the control group as in the study group, whereas for 1935 there were only 1.1 times as many. Since breast cancer mortality increases with age, this bias favoured screening and can be adjusted for only by comparing the results within each birth-year cohort before they are pooled (Bjurstam 2003).

Entry dates were not defined but the birth year cohorts were randomised one at a time, beginning with the 1923 cohort in December 1982 and ending in April 1984 with the 1944 cohort. A similar proportion of women were excluded from the study and control groups, $254(1.2 \%)$ and $357(1.2 \%)$, because of previous breast cancer (Bjurstam 2003). Information on screening of the control group varied, ranging from three to seven years after randomisation (Bjurstam 1997; Bjurstam 2003; Nyström 1993, figure; Nyström 2000). We estimated an intervention contrast of five years. A valid comparison of benefits and harms of screening should be confined to this period.

\section{Assignment of cause of death}

The autopsy rate was $31 \%$ (Nyström 2000). Cause-of-death assessments were blinded.

\section{Likelihood of selection bias}

We classified the trial as suboptimally randomised.

The UK age trial (UK age trial 1991)

Population studied 
This trial included women aged 39 to 41 years who were randomised individually between 1991 and 1997 to an intervention group or a control group, in a ratio of 1:2. Women in the control group received no information about the trial. The trial was undertaken in 23 breast-screening units in England, Wales, and Scotland. Women were identified from lists of patients from general practitioners held on local Health Authority databases and randomisation was carried out stratified by practice. Prior to this, the general practitioners could remove women with previous breast cancer and others deemed inappropriate to invite for screening. From 1992 onwards the allocations were carried out on the Health Authority computer system with specifically written software. Before this, for women in three early centres, random numbers generated from the coordinating centre computer were applied to the lists.

\section{Comparability of groups}

We found baseline data only on age; the mean age was 40.38 and 40.39 years, respectively.

Thirty and 51 women (0.05\%) were excluded from analysis for similar reasons in the two groups. The intervention contrast was 10 years. A valid comparison of benefits and harms of screening should be confined to this period.

\section{Assignment of cause of death}

There was no information on autopsy rate; information on cause of death was obtained from the central register of the National Health Service.

\section{Likelihood of selection bias}

We classified the trial as adequately randomised.

\section{Sources of data used for the meta-analyses}

Deaths ascribed to breast cancer: Alexander 1999; Andersson 1988; Bjurstam 1997; Bjurstam 2003; Frisell 1997; Habbema 1986; Miller 1992a; Miller 1992b; Miller 2000; Miller 2002; Moss 2006; Nyström 1993; Nyström 1993a; Nyström 2002; Roberts 1990; Shapiro 1977; Shapiro 1982; Tabar 1988; Tabar 1995.

Mortality among breast cancer patients: Tabar 1988.

Deaths ascribed to cancer, all patients: Andersson 1988; Aron 1986; Miller 2000; Miller 2002; Shapiro 1988; Tabar 1988.

All-cause mortality: Andersson 1988; Aron 1986; Bjurstam 1997; Miller 1992a; Miller 1992b; Miller 2000; Miller 2002; Moss 2006; Nyström 2000; Nyström 2002; Projektgruppen 1985; Roberts 1990; Shapiro 1977; Tabar 1989.

Mastectomies and lumpectomies: Andersson 1988; Frisell 1986; Frisell 1989a; Miller 1993; Shapiro 1972; Tabar 1999.

Radiotherapy: Andersson 1988; Benjamin 1996; Shapiro 1972; Tabar 1999.

Chemotherapy and hormone therapy: Andersson 1988; Tabar 1999.

Number of cancers: Andersson 1988; Bjurstam 1997; Frisell 1989a; Miller 1993; Moss 2005; Tabar 1991.

\section{Effects of interventions}

Eight trials provided data. We classified three trials as adequately randomised (Canada, Malmö and UK age trial) and four as suboptimally randomised (Göteborg, New York, Stockholm, TwoCounty), as was also the extension of the Malmö trial, MMST II. One trial (Edinburgh) was not adequately randomised and cannot provide reliable data; we have therefore only shown its results for completeness, in a separate graph. As the results from the UK age trial were obtained after a mean follow up of 10.7 years, we included them in the results both after 7 and after 13 years. The adequately randomised trials provided $40 \%$ of the breast cancer deaths after 13 years (Analysis 1.2).

\section{Deaths ascribed to breast cancer}

We judged assignment of breast cancer mortality to be unreliable and biased in favour of screening (see above and 'Discussion'), but included this outcome because it was the main focus in all trials.

The three adequately randomised trials did not find a statistically significant effect of screening on deaths ascribed to breast cancer, relative risk (RR) $0.93(95 \% \mathrm{Cl} 0.79$ to 1.09$)$ after 7 years and RR $0.90(95 \% \mathrm{Cl} 0.79$ to 1.02$)$ after 13 years. The four suboptimally randomised trials found a beneficial effect: RR $0.71(95 \% \mathrm{Cl} 0.61$ to 0.83 ) after 7 years and RR 0.75 ( $95 \% \mathrm{Cl} 0.67$ to 0.83 ) after 13 years. For all seven trials taken together the RR was 0.81 ( $95 \% \mathrm{Cl} 0.72$ to 0.90$)$ after 7 years and RR $0.81(95 \% \mathrm{Cl} 0.74$ to 0.87$)$ after 13 years. This result is less reliable, however, than that based on the adequately randomised trials.

The adequately randomised trials did not find a statistically significant effect of screening on deaths ascribed to breast cancer in the youngest age group (under 50 years of age at randomisation except for 7 year data from Malmö for which the limit was 55 years): RR 0.94 (95\% Cl 0.78 to 1.14) after 7 years and RR 0.87 (95\% Cl 0.73 to 1.03$)$ after 13 years. The suboptimally randomised trials found an RR of $0.81(95 \% \mathrm{Cl} 0.63$ to 1.05$)$ after 7 years and RR of 0.80 $(95 \% \mathrm{Cl} 0.64$ to 0.98$)$ after 13 years. For the oldest age group, the estimates for the adequately randomised trials were RR 0.88 (95\% $\mathrm{Cl} 0.64$ to 1.20 ) and RR 0.94 ( $95 \% \mathrm{Cl} 0.77$ to 1.15 ), respectively; for suboptimally randomised trials they were RR $0.67(95 \% \mathrm{Cl} 0.56$ to 0.81 ) and $\mathrm{RR} 0.70$ ( $95 \% \mathrm{Cl} 0.62$ to 0.80$)$, respectively.

\section{Deaths ascribed to any cancer}

The adequately randomised trials did not find an effect of screening on deaths ascribed to any cancer, including breast cancer (RR 1.02, $95 \% \mathrm{Cl} 0.95$ to 1.10); the follow up was 10.5 years for Canada and 9 years for Malmö (data were not available for the UK age trial). The suboptimally randomised trials did not provide reliable estimates of cancer mortality (see above); the estimate for the two suboptimally randomised trial that provided data (New York and Two-County trials) was RR 0.99 ( $95 \% \mathrm{Cl} 0.93$ to 1.06 ).

\section{All-cause mortality}

All-cause mortality was not significantly reduced (RR $0.98,95 \% \mathrm{Cl}$ 0.94 to 1.03 after 7 years; and RR $0.99,95 \% \mathrm{Cl} 0.95$ to 1.03 after 13 years) for the three adequately randomised trials. The suboptimally randomised trials did not provide reliable estimates of the effects on all-cause mortality (see 'Risk of bias in included studies' and 'Discussion') and the reported effects were heterogeneous ( $P=$ 0.03 after 7 years; $P=0.001$ after 13 years). For completeness, the mortality estimates are shown in the graphs. 


\section{Surgery}

Significantly more breast operations (mastectomies plus lumpectomies) were performed in the study groups than in the control groups: RR $1.31(95 \% \mathrm{Cl} 1.22$ to 1.42$)$ for the adequately randomised trials; RR $1.42(95 \% \mathrm{Cl} 1.26$ to 1.61$)$ for the suboptimally randomised trials before systematic screening in the control group started (data were available only for Kopparberg and Stockholm). The increased surgery rate could not be explained by the excess of detected tumours at the first screen but seemed to persist, as the mean follow up was seven years for Canada and nine years for Malmö. For Stockholm, the reported data after five years had been transformed according to the smaller size of the control group (Frisell 1989a). We recorrected and found that also for this trial the excess of surgery persisted (RR 1.37 after first round; RR 1.48 after five years).

The number of mastectomies (excluding partial mastectomies, quadrantectomies and lumpectomies) was also significantly increased: RR $1.20(95 \% \mathrm{Cl} 1.08$ to 1.32$)$ for the adequately randomised trials; RR $1.21(95 \% \mathrm{Cl} 1.06$ to 1.38$)$ for the suboptimally randomised trials.

\section{Radiotherapy}

Significantly more women received radiotherapy in the study groups: RR 1.24 ( $95 \% \mathrm{Cl} 1.04$ to 1.49) for Malmö after nine years; and RR 1.40 ( $95 \% \mathrm{Cl} 1.17$ to 1.69$)$ for Kopparberg before the control group screen.

\section{Other adjuvant therapy}

We found little information on other adjuvant therapy. It differed substantially for two of the Swedish trials even though they were carried out at the same time. Chemotherapy was given to only $7 \%$ of the breast cancer patients in Malmö but to 31\% in Kopparberg before the control group was screened (Analysis 1.17). Conversely, hormone therapy was given to $17 \%$ in Malmö, and to $2 \%$ in Kopparberg (Analysis 1.18). Information exists from Kopparberg on therapeutic adjuvant therapy given over the years but has not been published (Tabar 1999).

\section{Harms}

We found no comparative data on psychological morbidity. Duration of sick leave and mobility of the shoulder were recorded in the Two-County trial (Rapport 1982) but have not been reported.

\section{DISCUSSION}

The decision to embark on the screening programmes was made mainly because of the positive results in the New York and Two-County trials (Forrest report 1986). Policy makers and many scientists believed that the benefit of screening was well documented. However, information essential to judging the reliability of the trials was often unpublished or published only in Swedish, in theses, letters, conference reports, reviews, or in journals that are not widely read and with titles and abstracts that did not indicate that important data were described. Furthermore, the harms of screening received very little attention.

\section{Breast cancer mortality}

The main focus in the screening trials was breast cancer mortality, as very large trials are needed to assess the effect of screening on all-cause mortality. We cannot assume, however, that a beneficial effect on breast cancer mortality can be translated into improved overall survival. First, screening may increase mortality because of the increased use of radiotherapy. A meta-analysis predicted that overall, radiotherapy is beneficial for women at high risk of local recurrence. However, it is harmful for women at particularly low risk such as those who have their cancers found by screening. This is primarily because of damage to the coronary arteries and development of heart failure resulting from at least some types of radiotherapy (EBCTCG 2000) and because radiotherapy causes lung cancer. A meta-analysis of radiotherapy showed that there was a $27 \%$ excess mortality from heart disease and a $78 \%$ excess mortality from lung cancer (EBCTCG 2005a). This excess mortality becomes important when many healthy women are overdiagnosed.

Second, assessment of cause of death is susceptible to bias. The authors of the Two-County trial assessed cause of death openly and reported a $24 \%$ reduction in breast cancer mortality for Östergötland (Tabar 2000), whereas a meta-analysis of the Swedish trials based on an official cause of death register reported only a $10 \%$ reduction for Östergötland (Nyström 2002). The trial authors reported 10 fewer deaths from breast cancer in the study group despite slightly longer follow up, and 23 more deaths in the control group. They have not provided a plausible explanation of this large discrepancy (Duffy 2002; Tabar 2002). In 2009, "a complete audit of breast cancer cases and death" in the Two-County trial was published, but it is not convincing (Holmberg 2009). There was no blinding; it was not an independent audit; there was no attempt at producing a new data set based on the clinical records (which were only retrieved "where necessary"); and the Two-County trialists were directly involved with interpretations and resolving disagreements.

The bias seems to favour screening even when cause of death is determined blindly. In the New York trial, differential misclassification might be responsible for about half of the reported breast cancer mortality benefit. A similar number of dubious cases were selected for blinded review from each group, but a much smaller proportion of the screened group were finally classified as having died from breast cancer (Gøtzsche 2004). Furthermore, although the mammographic equipment was standard at the time, its performance was poor. Only $15 \%$ of 299 cancers in the study group were detected solely by mammography, and mammography did not identify a single case of minimal breast cancer $(<1 \mathrm{~cm})$ (Thomas 1977). The New York trial reported a $35 \%$ reduction in breast cancer mortality after seven years, but we consider it unlikely that it was a true effect.

In conjunction with the first meta-analysis of the Swedish trials, causes of death were reclassified blindly in some patients (Nyström 1993). Breast cancer was considered the underlying cause of death in 419 of the screened group and 409 of the control group according to Statistics Sweden, and in 418 and 425 cases according to the committee (Nyström 1993). The fact that all 17 reclassifications favoured the screened group suggests differential misclassification. This bias is difficult to avoid (Gøtzsche 2001). Early cancers are treated by lumpectomy and radiotherapy, and radiotherapy reduces the rates of local recurrence by about two-thirds (EBCTCG 2000). This might increase the likelihood that deaths among screen-detected breast cancer cases will be misclassified as deaths from other causes (EBCTCG 1995) and that too many deaths in the control group will be misclassified as breast cancer deaths. In fact, for the Swedish trials it was stated that "most patients with locally advanced disease will die due to cancer" and that breast cancer as the underlying cause of death includes 
women with locally advanced breast cancer, whereas women who have been treated successfully should not be classified as having breast cancer deaths if another specified disease could be the cause of death (Nyström 2000). The use of an official cause of death register as in more recent meta-analyses (Nyström 2002) cannot solve these problems.

Postrandomisation exclusion of women who already had breast cancer at the time of entry to the trial is another possible source of bias. The exclusions were sometimes made many years after the trial started, or even after it had ended. In the Two-County trial, only women who were considered to have died from breast cancer were excluded (Nixon 2000), a highly bias-prone process because those assessing cause of death were not blinded for screening status. Furthermore, the process seemed not to have been adequately monitored as it was not possible to identify prior breast cancers in Östergötland, by cluster (Nixon 2000). It should therefore not be possible to do analyses that respect the clustering with those women excluded, although such analyses have been reported (Tabar 1989; Tabar 1990; Tabar 1991; Tabar 1995). A study that used the same registers as those used by the trialists found that a large number of breast cancer cases and deaths seemed to be missing in reports on the Two-County trial (Zahl 2006). Another study found that the large reduction in breast cancer mortality agreed poorly with the cancer stages that were reported (Zahl 2001).

The largest effects on breast cancer mortality were reported in trials that had long intervals between screenings (Two-County trial), invited a large fraction of the women to only two or three screenings (Two-County and Stockholm trials), started systematic screening of the control group after three to five years (Two-County, Göteborg and Stockholm trials), had only one-view mammography rather than two views (Two-County trial), and that had poor equipment for mammography (New York trial); and the cancers found with mammography were considerably smaller in the Canadian trial than in the Two-County trial (Narod 1997). This suggests that differences in reported effects are related to the risk of bias in the trials rather than to the quality of the mammograms or the screening programmes. The sensitivity of mammographic readings in the trials that followed the New York trial has not consistently improved (Fletcher 1993; IARC 2002) and meta-analyses have failed to find an association between mammographic quality and breast cancer mortality (Glasziou 1995; Kerlikowske 1995). A metaanalysis found that the effect of screening was largest in those trials that found fewest node-positive cancers in the screened group relative to the control group (Gøtzsche 2011). However, the regression line was in the wrong place. A screening effectiveness of zero (same proportion of node-positive cancers in the screened group as in the control group) predicted a significant $16 \%$ reduction in breast cancer mortality after 13 years $(95 \% \mathrm{Cl} 9 \%$ to $23 \%$ reduction). This can only occur if there is bias, and there was bias for both variables, assessment of cause of death and of the number of node-positive cancers.

Several of the trials had clinical examination or regular selfexamination of the breasts as part of their design (see 'Description of studies') but this is not likely to have had a major influence on the effect estimates. The effect of clinical examination is uncertain, and large randomised trials did not find an effect of self-examination (Kösters 2003).

\section{Cancer mortality}

The major difficulty in assessing cause of death might have occurred when the patients were diagnosed with more than one malignant disease (Miller 2001). The importance of autopsy is illustrated by the fact that $21 \%$ of the women with breast cancer who died in the Malmö trial had two or three types of different cancers (Andersson 1988a; Janzon 1991). Patients with cachexia and no signs of recurrence of breast cancer would likely be assigned to another type of cancer.

Since cancer mortality is likely to be less subject to bias than breast cancer mortality, we calculated what the expected cancer mortality (including breast cancer mortality) would be if the reported reduction in breast cancer mortality of $29 \%$ after seven years for the suboptimally randomised trials (Analysis 1.1) were true. Weighting the four trials that provided data on number of cancer deaths (Analysis 1.7), the expected relative risk was 0.95 . However, all-cancer mortality in these trials was not reduced (RR $1.00,95 \% \mathrm{Cl} 0.96$ to 1.05 ), and this estimate was significantly higher than what was expected $(P=0.02)$. This provides further evidence that assessment of cause of death was biased in favour of screening. Data from the Two-County trial (Tabar 1988) illustrates the misclassification directly (Analysis 1.19) (Gøtzsche 2004). Among women with a diagnosis of breast cancer, mortality for other cancers was significantly higher in the screened group and mortality from all other causes also tended to be higher. The increase in mortality for causes other than breast cancer amounts to $38 \%$ of the reported decrease in breast cancer mortality in the Kopparberg part of the trial and 56\% in the Östergötland part.

It has been shown that belief in the effectiveness of an intervention may influence the decision on which type of cancer caused the patient's death (Newschaffer 2000). Also, lethal complications of cancer treatments are often ascribed to other causes. The size of this misclassification is 37\% for cancer generally and $9 \%$ for breast cancer (Brown 1993).

\section{All-cause mortality}

The trials were not powered to detect an effect on all-cause mortality, but it is an important outcome since the findings related to breast cancer mortality may be biased. The complex designs and insufficient reporting precluded us from providing reliable estimates for all-cause mortality in the trials with suboptimal randomisation. Furthermore, these trials had introduced early screening of the control group or had differentially excluded women after randomisation. Incidentally, however, all-cause mortality after 13 years was the same in adequately randomised trials and in suboptimally randomised trials (RR 0.99, $95 \% \mathrm{Cl} 0.95$ to 1.03 ; and $\mathrm{RR} 0.99,95 \% \mathrm{Cl} 0.97$ to 1.01 , respectively).

In 2000, the estimate reported for the four Swedish trials was RR 1.00 (95\% Cl 0.98 to 1.02) after adjustment for imbalances in age (Nyström 2000). In 2002, the authors reported a $2 \%$ (nonsignificant) reduction in all-cause mortality (RR $0.98,95 \% \mathrm{Cl} 0.96$ to 1.00 ) and stated that they would have expected a $2.3 \%$ reduction (Nyström 2002). However, the calculation was incorrect and the expected reduction, given their results, was only $0.9 \%$ (Gøtzsche 2002a). The error has been acknowledged (The Lancet Erratum 2002; Nyström 2002a) but the published response to our criticism was also incorrect (Nyström 2002b). The reported decrease of $2 \%$ in total mortality corresponds to a $10 \%$ decrease in all-cancer mortality, which is not plausible (see 'Cancer mortality' above). 
The Östergötland part of the Two-County trial contributed about half of the deaths in the 2002 report and had a relative risk for all-cause mortality of 0.98 (Nyström 2002). The women were randomised to only 24 clusters. In the Edinburgh trial there were 87 clusters, but double as many in the invited group belonged to the highest socioeconomic level compared to the control group (Alexander 1994). Socioeconomic factors are strong mortality predictors and could easily explain a $2 \%$ reduction in all-cause mortality, but such data remain unpublished and are also unavailable for the other Swedish trials. It has been reported that pretrial breast cancer incidence and breast cancer mortality were similar in the study group and in the control group in Östergötland (Nyström 2002), but the power of the test was very low (Gøtzsche 2002a). In contrast, another report found that breast cancer mortality was $15 \%$ lower in the invited groups in the TwoCountry trial and that correction for this difference changed the estimate of the effect from a $31 \%$ reduction to a $27 \%$ reduction in breast cancer mortality (Duffy 2003).

It is not clear why the unadjusted and age-adjusted estimates for all-cause mortality were the same with an RR of 0.98 . The 2002 Swedish meta-analysis comprised 43,343 deaths whereas in the 2000 meta-analysis of 27,582 deaths the estimates were RR 1.06 (95\% Cl 1.04 to 1.08 ) (Gøtzsche 2000) and RR 1.00 (95\% Cl 0.98 to 1.02) (Nyström 2000), with non-overlapping confidence intervals. The Kopparberg part of the Two-County trial was not available for the 2002 meta-analysis, but this should not have made any difference since the RR for Kopparberg was 1.00 (95\% Cl 0.96 to 1.04) (Nyström 2000). The only other difference is that the extended data for the Malmö trial (MSST II) were included, but this trial contributed only 702 deaths $(1.6 \%)$.

All-cause mortality has been reported to be lower in the TwoCounty trial when the analysis was confined to women with breast cancer (Tabar 2002a). Such subgroup analyses are very unreliable, as are similar analyses in historically controlled studies (Tabar 2001; Tabar 2003a), since many breast cancer cases in the screened groups will have an excellent prognosis because of overdiagnosis and length bias (Berry 2002).

\section{Overdiagnosis and overtreatment}

Overdiagnosis is a consequence of cancer screening and an obvious source of harm (IARC 2002). Screening primarily identifies slow-growing cancers and cell changes that are biologically benign (Doll 1981; Ernster 1996; Fox 1979). This is because slow-growing tumours have existed for longer than fast-growing tumours in the detectable range of tumour sizes and are therefore more likely to be detected at a screening session (length bias). Survival of women with screen-detected cancers is therefore very high, for example 97\% in Malmö after 10 years (Janzon 1991). Even within the same stage, it is higher than for cancers detected clinically (Moody-Ayers 2000).

The level of overdiagnosis and overtreatment was about 30\% in the trials that did not introduce early screening in the control group, and somewhat larger in the suboptimally randomised trials before the control group screen. This is apart from the New York trial, which is unreliable since far more breast cancer cases were excluded from the screened group than from the control group (Shapiro 1977; Shapiro 1982; Shapiro 1989). The true increase in surgery is considerably larger than $30 \%$, however. As the excess surgery in the trials is very similar to the increase in diagnoses, reoperations have not been included, although many women are operated upon more than once. In New South Wales, for example, one third of women with carcinoma in situ had either mastectomy alone (19\%) or after breast conserving surgery (17\%) (Kricker 2000).

Large observational studies support these findings. Incidence increases of $40 \%$ to $60 \%$ have been reported for Australia, Finland, Norway, Sweden, UK and USA (Barratt 2005; Douek 2003; Fletcher 2003; Gøtzsche 2004; IARC 2002; Jonsson 2005; Morrell 2010; Ries 2002; Zahl 2004. In two additional studies, overdiagnosis was calculated as the percentage of all diagnoses, rather than the percentage of additional diagnoses; correcting for this gives an overdiagnosis of $45 \%$ in USA (Bleyer 2012) and $18-33 \%$ in Norway (Kalager 2012). The Norwegian estimate did not include carcinoma in situ and was also an underestimate for other reasons (Jørgensen 2012). A small study from Copenhagen claimed that it is possible to screen without overdiagnosis, but it showed the expected prevalence peak, had very little power and provided no statistical analyses in support of the claim (Olsen 2003). A study that included the whole of Denmark and also non-screened age groups found 33\% overdiagnosis (Jørgensen 2009a). A systematic review that adjusted for decreases in incidence, if any, in older age groups no longer screened, and also for the trend in background incidence, found an overdiagnosis of 35\% for invasive cancer and $52 \%$ when carcinoma in situ was included, in countries with organised screening programmes (Jørgensen 2009).

Data from the UK show that when screening was extended to the age group 65-70 years in 2001, a sharp rise in invasive breast cancer incidence occurred in these women although they had been offered screening many times when they were younger and had already contributed to a massive increase in the incidence of DCIS and invasive cancers (Jørgensen 2011). This is difficult to explain unless we assume that many screen-detected cancers would have regressed spontaneously if left alone, which is supported by a study from Norway with a strong design (Zahl 2008), and by a similarly designed study from Sweden (Zahl 2011). A US study also suggested that breast cancers regress, since the incidence declined much too rapidly after the use of hormone replacement therapy stopped (Chlebowski 2009). Another US study, of the breast cancer incidence and mortality rates during the period 1975 to 2000 when screening was introduced found that, in order to explain the observed trends, it was necessary to postulate that approximately $40 \%$ of the observed cancers had limited malignant potential and would have regressed if undetected (Fryback 2006).

Screening increased the number of mastectomies by $20 \%$. Since screening advances the time of diagnosis, a policy change towards more lumpectomies could have led to an overestimate. However, the policy change has occurred slowly (Nattinger 2000) and even in the period 1993 to $1995,52 \%$ of breast surgery in California was mastectomy (Malin 2002). In Stockholm, the increase in mastectomies was larger after five years of screening $(25 \%)$ than after the first round (16\%), and when screening was introduced in Southeast Netherlands, the rate of breast-conserving surgery increased by $71 \%$ while the rate of mastectomy increased by $84 \%$ (Gøtzsche 2002) despite the fact that this study did not include carcinoma in situ. The percentage of cases of carcinoma in situ treated by mastectomy declined from $71 \%$ in 1983 to $40 \%$ in 1993 in USA, but the estimated total numbers of mastectomies for this condition increased almost three-fold (Ernster 1997). In the UK, mastectomies increased by $36 \%$ for invasive cancer and by $422 \%$ for carcinoma in situ from 1990 to 2001 (Douek 2003). Carcinoma 
in situ is more often treated by mastectomy than invasive cancer (Patnick 2012).

Conversely, use of mammography in the control group would lead to an underestimate of overdiagnosis. In the trials from Malmö and Canada, 24\% (Andersson 1988), 17\% (Miller 1992b) and 26\% (Baines 1994) of the women in the control group reported having received a mammogram during the trial; in the Two-County trial, it was 13\% (Tabar 1985); in the Göteborg trial, $18 \%$ of women in the control group received a mammogram in a two-year period during the trial (Bjurstam 2003). In the Stockholm trial, 25\% of those attending the first screening had had a mammogram in the two previous years (Frisell 1989a), and in the Göteborg trial, as many as $51 \%$ of the women in the age group 39-49 had ever received a mammogram (Bjurstam 1997). It is difficult to understand that this trial, with so much contamination reducing the observed benefit, found a $45 \%$ reduction in breast cancer mortality.

The documented increase in mastectomies contrasts with assertions by trialists (Tabar 1989), policy makers (Statusrapport 1997; Swed Cancer Soc 1996; Westerholm 1988), websites supported by governmental institutions and advocacy groups (Jørgensen 2004), and invitational letters sent to women invited to screening (Jørgensen 2006; Gøtzsche 2009) that early detection spares patients more aggressive treatments, in particular mastectomy. Publications that base their claims on numbers that include the control group screen (Tabar 2003) are also misleading, as are presentations of relative numbers rather than absolute numbers (Statusrapport 1997). The proportion of breast preserving operations is said to be increasing, but the trend for the number of mastectomies is not revealed. A small study from Florence, without a control group (Paci 2002), was also unreliable (Gøtzsche 2002b). The authors asserted that if screening increased the number of mastectomies, populations in which screening has been introduced should see a subsequent increase. Obviously, since the mastectomy rate has gone down steadily throughout many years, also in countries without screening, it is only to be expected that the authors found a decrease in the mastectomy rate when screening was introduced.

Denmark has a unique control group, as only $20 \%$ of the population was screened throughout 17 years. The large increase in mastectomies when screening was introduced has not been compensated later or in older age groups (Jørgensen 2011). A study from Norway has confirmed this (Suhrke 2011).

Quality assurance programmes could possibly reduce the surgical activity to some degree, but they could also increase it. In the UK, for example, the surgeons were blamed for not having treated even more women with carcinoma in situ by mastectomy (BASO audit 2000), and the number of women treated by mastectomy almost doubled from 1998 to 2008 (Dixon 2009).

Two to three years after breast cancer treatment, $47 \%$ of the women reported pain, usually several times a week (Gärtner 2009). Only half of those with pain reported that it was light (corresponding to 1-3 on a 10-point scale). The pain was equally common among those who had had breast-conserving surgery as among those with a mastectomy, and pain was more common when the women had had radiotherapy. Thus, half of all the overdiagnosed women will suffer from chronic pain, presumably for the rest of their lives.
False-positive diagnoses can cause considerable and sustained psychological distress (Bülow 2000; Salz 2010), not only until it is known whether or not there is a cancer (Brodersen 2006) but for years after the women are declared free from cancer (Brodersen 2013). Many women experience anxiety, worry, despondency, sleeping problems, negative impact on sexuality and behaviour, and changes in their relationships with family, friends, and acquaintances as well as in existential values (Brodersen 2006; Brodersen 2007; Brodersen 2013; Salz 2010). In a large study that compared women with normal findings, women with false-positive diagnoses and women with breast cancer, the severity of the psychological distress for women with false-positive findings was between that for healthy women and those with breast cancer even three years after they had been declared free from cancer (Brodersen 2013). Some women will feel more vulnerable about disease and see a doctor more often (Barton 2001).

In the Stockholm trial, one-third of women with false-positive findings were not declared cancer-free at six months (Lidbrink 1996). In the UK, women who had been declared cancer-free after additional testing or biopsies were twice as likely to suffer psychological consequences three years later than women who received a clear result after their last mammogram (Brett 2001). In the USA, three months after they had false-positive results $47 \%$ of women who had highly suspicious readings reported that they had substantial anxiety related to the mammogram, $41 \%$ had worries about breast cancer, $26 \%$ reported that the worry affected their daily mood, and $17 \%$ that it affected their daily function (compared to $3 \%$ with a normal mammogram) (Lerman 1991). In Norway, 18 months after screening mammography $29 \%$ of women with falsepositive results and $13 \%$ of women with negative results reported anxiety about breast cancer (Gram 1990).

The cumulative risk of a false-positive result after 10 mammograms ranges from about 20\% to $60 \%$ (Barratt 2005; Castells 2006; Christiansen 2000; Elmore 1998; Hofvind 2004; Hubbard 2011; Johns 2010; Njor 2007). It is considerably higher in USA than elsewhere, e.g. the recall rate in women aged 50 to 54 years was $13 \%$ to $14 \%$ after the first mammogram, compared to $8 \%$ in the UK (Smith-Bindman 2003). The reported percentages are often too low because recalls due to poor technical quality of the mammogram are not included (Hofvind 2004; Johns 2010; Njor 2007), although these women may be just as affected by such recalls as by a real suspicion of cancer (Brodersen 2006). In USA, 19\% would have had a biopsy after 10 mammograms (Elmore 1998).

Thus, it seems that screening inflicts important psychological distress for years on more than a tenth of the healthy population of women who attend a screening programme. The women are often not being informed about this risk (Gøtzsche 2009; Jørgensen 2004; Jørgensen 2006; Slaytor 1998; Werkö 1995) or the risk of receiving a diagnosis of carcinoma in situ (Gøtzsche 2009; Jørgensen 2004; Thornton 1997).

About half of the women report that it is painful to have a mammogram taken (Armstrong 2007; Miller 2002a; McNoe 1996), and half of the women who decline an invitation to the second round of screening note that the major reason was that their first mammogram was painful (Elwood 1998).

Other recent reviews of screening

\section{False- positive diagnoses, psychological distress and pain}


Previous reviews have generally not heeded the methodological quality of the trials, but when the methods were assessed blindly the researchers judged the Canadian trial to be of high quality and the Two-County trial to be of poor quality (Glasziou 1995).

Prompted by our first Cochrane review in 2001, the US Preventive Services Task Force performed an updated systematic review (Humphrey 2002). It excluded the Edinburgh trial and reported a $16 \%$ reduction in breast cancer mortality for all ages. The authors noted that, "the mortality benefit of mammography screening is small enough that biases in the trials could erase or create it" and were concerned whether, across all age groups, the magnitude of benefit is sufficient to outweigh the harms. The Task Force gave mammography screening a grade $\mathrm{B}$ recommendation (US Task Force 2002). The Task Force reported a 15\% reduction in breast cancer mortality for those aged 39 to 49 years in 2009 and larger effects in older age groups (Nelson 2009). A comprehensive IARC report (IARC 2002) was not a systematic review and paid little attention to the varying quality of the trials; it even included a non-randomised study in its meta-analysis. A 2012 UK report was not a systematic review either (UK review 2012). It used data from the Cochrane review for the benefit, but did not adjust the estimation of the effect to account for the varying quality of the trials or the improvements in treatment and breast cancer awareness. The report focussed on breast cancer mortality, and ignored all cause mortality, which may bias its findings in favour of breast screening. It acknowledged that previous estimations of the benefits and harms of mammography screening had been overoptimistic and acknowledged uncertainties around estimations of the magnitude of effect. It did not use the Cochrane review estimate of overdiagnosis but a smaller one that was diluted because of screening in the control group (Welch 2006).

The meta-analyses of the Swedish trials are not systematic reviews as they do not include all relevant trials. There is a high risk of bias in cluster randomised trials with few clusters (Puffer 2003) and numbers of randomised women were inconsistently reported (Table 1). In Stockholm, for example, the number of randomised women decreased by $4.5 \%$ in the screening group but increased by 3.6\% in the control group (Gøtzsche 2000) in the Swedish 1993 review (Nyström 1993) compared to the trial report (Frisell 1997). In the 2000 and 2002 reviews (Nyström 2000; Nyström 2002), numbers have increased by $1.6 \%$ in both groups but should have been the same as in the 1993 report since all women were identified through their unique identification number (Nyström 2002), which has been used in Sweden for several decades; exclusions of women with previous breast cancer was completed with the 1993 review; and all three reviews were based on the exact age at randomisation, and the age range was the same. The varying numbers therefore indicate that the randomisation was not respected. The estimates in the Swedish reviews were adjusted for differences in age, but since the distribution of age would be expected to differ over socioeconomic strata such adjustment would be expected to lead to other imbalances (Gøtzsche 2000). Furthermore, simulation studies have shown that adjustments quite often increase bias rather than reduce it (Deeks 2003). The most recent review of the Swedish trials reported a $15 \%$ reduction in breast cancer mortality with the follow-up model (Nyström 2002); another estimate of $21 \%$ was based on an 'evaluation model', which is flawed, as it ignores breast cancer deaths among women in the control group whose breast cancer diagnosis was made after the first screening round of the control group (Berry 1998).

\section{What were the absolute effects of screening in the trials?}

The largest reported effect in the Swedish trials collectively is a $29 \%$ relative reduction in breast cancer mortality for women aged 50 to 69 years, which corresponds to an absolute reduction in breast cancer mortality of $0.1 \%$ after 10 years (Nyström 1993). According to the Cochrane Handbook (Higgins 2008), the primary analysis in a systematic review should be based on studies at low risk of bias, and these studies showed only a $7 \%$ relative reduction in breast cancer mortality after 7 years and $10 \%$ after 13 years. We therefore believe that a realistic estimate is a $10-15 \%$ relative reduction in breast cancer mortality in the trials. This is also what one would expect based on tumour data. The average difference in tumour size between the screened and the control groups was only $5 \mathrm{~mm}$, which predicts a $12 \%$ reduction in breast cancer mortality since tumour size is linearly related to the risk of metastasis (Gøtzsche 2012a). The $12 \%$ reduction is an overestimate because the small overdiagnosed tumours inflate the difference in size of tumours, which must be less than $5 \mathrm{~mm}$ for clinically relevant tumours.

The trials did not find a reduction in all-cancer mortality and our estimate could therefore be an overestimate. But if we assume the effect is $15 \%$, it means that for every 2000 women invited for screening throughout 10 years, one will avoid dying of breast cancer. This number can be deduced from the first meta-analysis of the Swedish trials, taking into account that the effect is only half as large as indicated in that paper (Nyström 1993, page 976). It can also be deduced from our review. After seven years (Analysis 1.1), there were 384 deaths from breast cancer in the adequately randomised trials out of 173,061 women in the control group, and a $15 \%$ effect corresponds to 326.4 deaths in a study group of the same size, which gives 0.7 women per 2000 .

Similarly, if we assume that the level of overdiagnosis is $30 \%$, which might be an underestimate, it means that for every 2000 women invited for screening throughout 10 years, 10 healthy women who would not have had a breast cancer diagnosis if there had not been screening will be diagnosed as cancer patients, and will be treated unnecessarily (see Analysis 1.14; there were 1083 cancers in the control group in the adequately randomised trials out of 66,154 women, which gives 325 overdiagnosed cancers, or 9.8 per 2000). In addition, it is likely that more than 200 women will experience important psychological distress for many months because of falsepositive findings.

\section{What is the effect of screening today?}

There have been substantial advances in treatment since the trials were performed. Anti-hormones and polychemotherapy are effective also when the cancer has metastasized (EBCTCG 2005), and the declines in breast cancer mortality we have seen (Autier 2010) have occurred rather uniformly across prognostic groups (Blamey 2007). An updated meta-analysis of polychemotherapy showed that some regimens reduce breast cancer mortality by about one third, largely independently of tumour characteristics (EBCTCG 2012). This means that the effect of screening must be smaller today than when the trials were conducted in terms of the number of women who avoid dying of breast cancer.

In order to be effective, screening would of necessity need to lead to a reduction in the number of advanced cancers at diagnosis. In the USA, there has been a very small decrease in advanced cancers (Esserman 2009; Jørgensen 2011). A detailed analysis of a 
time period spanning 30 years showed that the incidence of earlystage breast cancer in USA went up from 112 to 234 cases per 100,000 women (a 109\% increase) while the incidence of late-stage cancer decreased by $8 \%$, from 102 to 94 cases per 100,000 women (Bleyer 2012). Moreover, the small decline in advanced cancers was confined to regional disease involving the lymph nodes; there was no reduction in disease with distant metastases. A systematic review of several countries (Australia, Italy, Norway, Switzerland, the Netherlands, UK and the USA) found that, on average, the rate of cancers larger than $20 \mathrm{~mm}$ was not affected by screening (Autier 2011). In Norway, screening did not decrease the incidence of cancers in stages III and IV, as the reductions were exactly the same in screened and non-screened areas (Kalager 2012).

In contrast to screening, increased breast cancer awareness seems to have been important. In Denmark, the average tumour size at diagnosis was $33 \mathrm{~mm}$ in 1978-79, but only $24 \mathrm{~mm}$ ten years later, in 1988-89 (Rostgaard 2010). This change occurred before screening started, and in contrast to screening, breast cancer awareness is unlikely to cause overdiagnosis. The difference of $9 \mathrm{~mm}$ is much greater than the average difference between the screened and the control groups in the trials, which was only $5 \mathrm{~mm}$ (Gøtzsche 2012a), despite the fact that the small overdiagnosed tumours would tend to spuriously exaggerate the difference. In Canada, the size of clinically detected tumours decreased by $4 \mathrm{~mm}$ from 1987 to 1999 (Narod 2011).

There are many poor observational studies claiming large effects of screening, but they often use statistical models with unsupported assumptions or misleading comparisons (Gøtzsche 2010; Gøtzsche 2012). The better studies rely on unmodified data. As noted above, Denmark has a unique control group, as only $20 \%$ of the population was screened throughout 17 years. The annual decline in breast cancer mortality in the relevant age group and time-period was $1 \%$ in the screened areas and $2 \%$ in the non-screened areas. In women who were too young to benefit from screening the declines were larger, $5 \%$ and $6 \%$, respectively (Jørgensen 2010). Also in the UK, Sweden and Norway, there was no visible effect of screening when age groups were compared (Jørgensen 2010; Kalager 2010; Jørgensen 2011). The Norwegian study (Kalager 2010) was criticized because of short follow-up, but the follow-up from start of screening was 6.6 years, which is when an effect was seen in the trials.

A study reported a $15 \%$ effect in the USA (Berry 2005), but the authors noted that the decline in breast cancer mortality coincided not only with widespread propagation of screening but also with increasing use of adjuvant therapy. They also noted that slight variations in modelling assumptions could result in marked changes in estimated effects. Further, the statistical models adjusted for an increase in breast cancer incidence, which was inappropriate, as much of this increase was overdiagnosis. Unlike the USA, women below age 50 years are rarely offered screening in Europe. The mean decline in breast cancer mortality between 1989 and 2005 in these women was $37 \%$, whereas it was $21 \%$ in women aged 50-69 years (Autier 2010). The declines began before organised screening in many countries and fitted better with the introduction of tamoxifen, which explains the larger decline in young women who often have oestrogen-sensitive tumours (Jørgensen 2011). A comparison of three pairs of neighbouring European countries that had introduced screening 10-15 years apart showed no relation between screening start and the reductions in breast cancer mortality (Autier 2011a); in fact, the reduction in breast cancer mortality was about the same in the six European countries as in USA (Bleyer 2011). An Australian study found that most, if not all, of the reduction in breast cancer mortality could be attributed to adjuvant hormonal and chemotherapy (Burton 2011).

Screening advocates have claimed that screening explains why breast cancer mortality rates are lower in Sweden than in Denmark (Dean 2010), but this difference existed decades before screening. Further, the reductions in breast cancer mortality in the screening period were largest in Denmark, $49 \%$ versus 36\% in Sweden in women under 50, although half of these women are invited in Sweden versus none in Denmark (Autier 2010). In those aged 50-69 years, the reduction was $26 \%$ in Denmark versus $16 \%$ in Sweden, although only $20 \%$ of Danish women were invited, versus all in Sweden where more than $80 \%$ participated (Autier 2010; IARC 2002). Despite having the longest running programme, the widest invited age range, and the shortest screening interval in Europe (IARC 2002), Sweden has experienced lower reductions in breast cancer mortality than the European median (Autier 2010).

These studies taken in combination cast doubt as to the effectiveness of screening today. Even if screening still reduces breast cancer mortality, the effect on all-cause mortality remains uncertain. However, both the randomised and non-randomised studies provide evidence that screening causes substantial overdiagnosis.

\section{AUTHORS' CONCLUSIONS}

\section{Implications for practice}

We believe that the time has come to re-assess whether universal mammography screening should be recommended for any age group. Declining rates of breast cancer mortality are mainly due to improved treatments and breast cancer awareness, and therefore we are uncertain as to the benefits of screening today. Overdiagnosis has human costs and increases mastectomies and deaths. The chance that a woman will benefit from attending screening is small at best, and - if based on the randomised trials - ten times smaller than the risk that she may experience serious harm in terms of overdiagnosis. Women, clinicians and policy makers should consider the trade-offs carefully when they decide whether or not to attend or support screening programmes.

Screening advocates and their organisations have generally emphasised the benefits and omitted information on the major harms in their information materials (Dixon-Woods 2001; Gøtzsche 2012; Jørgensen 2004; NHS leaflet 2001; NHS leaflet 2010; US Task Force 2002) and in invitational letters (Jørgensen 2006; Gøtzsche 2009). Most women therefore tend to substantially exaggerate the benefits and to be unaware of the major harms of screening (Barratt 1997; Barratt 1999; Domenighetti 2003; Schwartz 2000). To help ensure that the requirements for informed choice for women contemplating whether or not to attend a screening programme can be met, we have written an evidence-based leaflet for lay people (Gøtzsche 2009). The leaflet has been carefully tested among general practitioners and lay people. It is available on the BMJ website in English (Gøtzsche 2009) and in several languages on the website of The Nordic Cochrane Centre at www.cochrane.dk. 
It has been suggested that resources be redirected to interventions with proven benefit in breast cancer (Baum 2000) or used for other purposes (NBCC 2002). For comparison, the benefit is at least 200 times greater when women with node-positive breast cancer are treated with tamoxifen since the average life extension is six months after 10 years (EBCTCG 1998).

\section{Implications for research}

Breast cancer mortality is an unreliable outcome measure in screening trials (and therefore also in cohort studies of the effectiveness of national programmes) and exaggerates the benefit. Because of the methodological problems with the screening trials and the reported analyses, it would be useful if independent researchers performed an individual patient data meta-analysis, where exclusions of randomised women were not allowed. It would also be useful to obtain data on all-cancer mortality for all the trials since misclassification of cause of death often concerns deaths from other cancers. Finally, research is needed to identify means of separating cancers likely to result in death from the many benign cancers identified by screening that do not need treatment.

\section{ACKNOWLEDGEMENTS}

We thank Freda Alexander, Ingvar Andersson, Cornelia Baines, Niels Bjurstam, Gunnar Fagerberg, Jan Frisell, Anthony B Miller and Sam Shapiro for comments on their trials, Friederike M Perl for pointing out an inconsistency in one of the trials, Mike Clarke for advice, Ole Olsen who was an author on the 2001 version of this review and wrote the draft section on methodological quality of the trials for that version, Kay Dickersin for comments on the 2006 update of the review, and Margrethe Nielsen who was an author on the 2006 and 2009 updates. 


\section{REFERE N CE S}

\section{References to studies included in this review}

Canada 1980 \{published and unpublished data\}

Bailar JC 3rd, MacMahon B. Randomization in the Canadian National Breast Screening Study: a review for evidence of subversion. Canadian Medical Association Journal 1997;156(2):193-9.

Baines CJ. Personal communication 18 Jan 2001.

Baines CJ. A different view on what is known about breast screening and the Canadian National Breast Screening Study. Cancer 1994;74(4):1207-11.

Baines CJ. Impediments to recruitment in the Canadian National Breast Screening Study: response and resolution. Controlled Clinical Trials 1984;5(2):129-40.

Baines CJ. NBSS: changes were made, suspicious changes were not [letter]. CMAJ 1997;157(3):248-50.

Baines CJ. The Canadian National Breast Screening Study. Why? What next? And so what?. Cancer 1995;76 Suppl(10):2107-12.

Baines CJ. The Canadian National Breast Screening Study: a perspective on criticisms. Annals of Internal Medicine 1994;120(4):326-34.

Baines CJ. The Canadian National Breast Screening Study: responses to controversy. Womens Health Issues 1992;2(4):206-11.

Baines CJ, Christen A, Simard A, Wall C, Dean D, Duncan L, et al. The National Breast Screening Study: pre-recruitment sources of awareness in participants. Canadian Journal of Public Health 1989;80(3):221-5.

Baines CJ, McFarlane DV, Miller AB. Sensitivity and specificity of first screen mammography in 15 NBSS centres. Canadian Association of Radiologists Journal 1988;39(4):273-6.

Baines CJ, McFarlane DV, Miller AB. The role of the reference radiologist. Estimates of inter-observer agreement and potential delay in cancer detection in the national breast screening study. Investigative Radiology 1990;25(9):971-6.

Baines CJ, McFarlane DV, Wall C. Audit procedures in the National Breast Screening Study: mammography interpretation. Canadian Association of Radiologists Journal 1986;37(4):256-60.

Baines CJ, Miller AB. Mammography versus clinical examination of the breasts. Journal of the National Cancer Institute. Monographs 1997;22:125-9.

Baines CJ, Miller AB, Bassett AA. Physical examination. Its role as a single screening modality in the Canadian National Breast Screening Study. Cancer 1989;63(9):1816-22.

Baines CJ, Miller AB, Kopans DB, Moskowitz M, Sanders DE, Sickles EA, et al. Canadian National Breast Screening Study: assessment of technical quality by external review. AJR. American Journal of Roentgenology 1990;155(4):743-7.
Baines CJ, Miller AB, Wall C, McFarlane DV, Simor IS, Jong R, et al. Sensitivity and specificity of first screen mammography in the Canadian National Breast Screening Study: a preliminary report from five centers. Radiology 1986;160(2):295-8.

Baines CJ, To T. Changes in breast self-examination behavior achieved by 89,835 participants in the Canadian National Breast Screening Study. Cancer 1990;66(3):570-6.

Baines CJ, To T, Wall C. Women's attitudes to screening after participation in the National Breast Screening Study. A questionnaire survey. Cancer 1990;65(7):1663-9.

Baines CJ, Vidmar M, Mckeown Eyssen G, Tibshirani R. Impact of menstrual phase on false-negative mammograms in the Canadian National Breast Screening Study. Cancer 1997;80(4):720-4.

Baines CJ, Wall C, Risch HA, Kuin JK, Fan IJ. Changes in breast self-examination behavior in a cohort of 8214 women in the Canadian National Breast Screening Study. Cancer 1986;57(6):1209-16.

Basinski AS. The Canadian National Breast Screening Study: opportunity for a rethink. CMAJ 1992;147(10):1431-4.

Boyd NF. The review of randomization in the Canadian National Breast Screening Study. Is the debate over?. CMAJ 1997;156(2):207-9

Boyd NF, Byng JW, Jong RA, Fishell EK, Little LE, Miller AB, et al. Quantitative classification of mammographic densities and breast cancer risk: results from the Canadian National Breast Screening Study. Journal of the National Cancer Institute 1995;87(9):670-5.

Boyd NF, Jensen HM, Cooke G, Han HL. Relationship between mammographic and histological risk factors for breast cancer. Journal of the National Cancer Institute 1992;84(15):1170-9.

Boyd NF, Jong RA, Yaffe MJ, Tritchler D, Lockwood G, Zylak CJ. A critical appraisal of the Canadian National Breast Cancer Screening Study. Radiology 1993;189(3):661-3.

Boyd NF, Lockwood GA, Martin LJ, Knight JA, Jong RA, Fishell E, et al. Mammographic densities and risk of breast cancer among subjects with a family history of this disease. Journal of the National Cancer Institute 1999;91(16):1404-8.

Boyd NF, Wolfson C, Moskowitz M, Carlile T, Petitclerc M, Ferri $\mathrm{HA}$, et al. Observer variation in the interpretation of xeromammograms. Journal of the National Cancer Institute 1982;68(3):357-63.

Bryant $\mathrm{H}$. The review of randomization in the Canadian National Breast Screening Study. What does the verdict mean for clinicians?. CMAJ 1997;156(2):213-5.

Burhenne LJ, Burhenne HJ. The Canadian National Breast Screening Study: a Canadian critique. American Journal of Roentgenology 1993;161(4):761-3. 
Busetti MC, Miller AB, To T, Rohan TE. Risk factors for breast cancer mortality among the National Breast Screening Study of Canada participants. Cancer Detection and Prevention 1996;20(2):122-9.

Cohen MM, Kaufert PA, MacWilliam L, Tate RB. Using an alternative data source to examine randomization in the Canadian National Breast Screening Study. Journal of Clinical Epidemiology 1996;49(9):1039-44.

Goel V, Cohen MM, Kaufert P, MacWilliam L. Assessing the extent of contamination in the Canadian National Breast Screening Study. American Journal of Preventive Medicine 1998;15(3):206-11.

Goldman B. When considering attacks against the National Breast Screening Study, consider the sources. CMAJ 1993;148(3):427-8.

Gray C. US resistance to Canadian mammogram study not only about data. CMAJ 1993;148(4):622-3.

Haiart DC, Henderson J. A comparison of interpretation of screening mammograms by a radiographer, a doctor and a radiologist: results and implications. The British Journal of Clinical Practice 1991;45(1):43-5.

Harvey BJ, Miller AB, Baines CJ, Corey PN. Effect of breast selfexamination techniques on the risk of death from breast cancer. CMAJ 1997;157(9):1205-12.

Holowaty PH, Miller AB, Baines CJ, Risch H. Canadian National Breast Screening Study: first screen results as predictors of future breast cancer risk. Cancer Epidemiology, Biomarkers \& Prevention 1993;2(1):11-9.

Howe GR, Sherman GJ, Semenciw RM, Miller AB. Estimated benefits and risks of screening for breast cancer. Canadian Medical Association Journal 1981;124(4):399-403.

Jain MG, Miller AB, Rohan TE, Rehm JT, Bondy SJ, Ashley MJ, et al. Body mass index and mortality in women: follow-up of the Canadian National Breast Screening Study cohort. International Journal of Obesity and Related Metabolic Disorders 2005;29(7):792-7.

Kopans DB, Feig SA. The Canadian National Breast Screening Study: a critical review. American Journal of Roentgenology 1993;161(4):755-60.

Kopans DB, Halpern E, Hulka CA. Mammography screening for breast cancer. Reply to the commentaries. Cancer 1994;74(4):1212-6.

Kopans DB, Halpern E, Hulka CA. Statistical power in breast cancer screening trials and mortality reduction among women 40-49 years of age with particular emphasis on the National Breast Screening Study of Canada. Cancer 1994;74(4):1196-203.

Miller AB. Canadian National Breast Screening Study: response [letter]. CMAJ 1993;149(10):1374-5.

Miller AB. Mammography in mass screening [letter]. European Journal of Cancer 1980;16(5):737-9.
Miller AB. More on breast cancer screening. Cancer Forum 1988;12:1-3.

Miller AB. Re: "Author of Canadian breast cancer study retracts warnings" [letter]. Journal of the National Cancer Institute 1992;84(17):1365-70.

Miller AB. Re: May we agree to disagree, or how do we develop guidelines for breast cancer screening in women? [letter]. Journal of the National Cancer Institute 1994;86(22):1729-31.

Miller AB. Routine mammography and the National Breast Screening Study. CMAJ 1984;130(3):259-60, 273.

Miller AB. The Canadian National Breast Screening Study: update on breast cancer mortality. NIH Consensus Development Conference on Breast Cancer Screening for Women ages 40-49. National Institutes of Health, 1997:51-3.

Miller AB. The Canadian national breast screening study. In: Day $\mathrm{NE}$, Miller AB editor(s). Screening for Breast Cancer. Toronto: Hans Huber, 1988:51-8.

Miller AB. The costs and benefits of breast cancer screening. American Journal of Preventive Medicine 1993;9(3):175-80.

Miller AB, Baines CJ, Sickles EA. Canadian National Breast Screening Study. American Journal of Roentgenology 1990;155:1133-4.

Miller AB, Baines CJ, To T, et al. The Canadian national breast screening study. In: Miller AB, Chamberlain J, Day NE, et al. editor(s). Cancer Screening. Cambridge: Cambridge University Press, 1991:45-55.

Miller AB, Baines CJ, To T, Wall C. Canadian national breast screening study [correction]. CMAJ 1993;148:718.

Miller AB, Baines CJ, To T, Wall C. Screening mammography reevaluated. The Lancet 2000;355:747.

Miller AB, Baines CJ, Turnbull C. The role of the nurse-examiner in the National Breast Screening Study. Canadian Journal of Public Health 1991;82(3):162-7.

Miller AB, Howe GR, Wall C. The National Study of Breast Cancer Screening Protocol for a Canadian Randomized Controlled trial of screening for breast cancer in women. Clinical and Investigative Medicine 1981;4(3-4):227-58.

Narod SA. On being the right size: A reappraisal of mammography trials in Canada and Sweden. The Lancet 1997;349:1849.

Simard A, Paquette L, Baillargeon J, Falardeau M. Perception of cancer detection and early treatment in a population participating in the National Breast Screening Study in Canada. Canadian Journal of Public Health 1989;80(3):226-7.

Canada 1980a \{published and unpublished data\}

Kopans DB. Canadian National Breast Screening Study [letter]. The Lancet 1997;350(9080):810.

Miller AB, Baines CJ, To T, Wall C. Canadian National Breast Screening Study: 1 . Breast cancer detection and death 
rates among women aged 40 to 49 years. Canadian Medical Association Journal 1992;147(10):1459-76.

Miller AB, To T, Baines CJ, Wall C. The Canadian National Breast Screening Study-1: breast cancer mortality after 11 to 16 years of follow-up. A randomized screening trial of mammography in women age 40 to 49 years. Annals of Internal Medicine 2002;137(5 Part 1):305-12.

Miller AB, To T, Baines CJ, Wall C. The Canadian National Breast Screening Study: update on breast cancer mortality. Journal of the National Cancer Institute. Monographs 1997;NA(22):37-41.

\section{Canada 1980b \{published and unpublished data}

Miller AB, Baines CJ, To T, Wall C. Canadian National Breast Screening Study: 2. Breast cancer detection and death rates among women aged 50 to 59 years. Canadian Medical Association Journal 1992;147(10):1477-88.

Miller AB, To T, Baines CJ, Wall C. Canadian National Breast Screening Study-2: 13-year results of a randomized trial in women aged 50-59 years. Journal of the National Cancer Institute 2000;92:1490-9.

\section{Edinburgh 1978 \{published data only\}}

Alexander F, Roberts MM, Lutz W, Hepburn W. Randomisation by cluster and the problem of social class bias. Journal of Epidemiology and Community Health 1989;43(1):29-36.

Alexander FE. The Edinburgh Randomized Trial of Breast Cancer Screening. Journal of the National Cancer Institute. Monographs 1997;22:31-5.

Alexander FE, Anderson TJ, Brown HK, Forrest AP, Hepburn W, Kirkpatrick $A E$, et al. 14 years of follow-up from the Edinburgh randomised trial of breast-cancer screening. The Lancet 1999;353(9168):1903-8.

Alexander FE, Anderson TJ, Brown HK, Forrest AP, Hepburn W, Kirkpatrick $A E$, et al. The Edinburgh randomised trial of breast cancer screening: results after 10 years of follow-up. British Journal of Cancer 1994;70(3):542-8.

Alexander FE, Anderson TJ, Donnan PT, Prescott RJ. Edinburgh trial of screening for breast cancer [letter]. The Lancet 1990;335(8695):969-70.

Alexander FE, Anderson TJ, Donnan PT, Prescott RJ. Edinburgh trial of screening for breast cancer [letter]. The Lancet 1990;335:1290-1.

Alexander FE, Anderson TJ, Hubbard AL. Screening status in relation to biological and chronological characteristics of breast cancers: a cross sectional survey. Journal of Medical Screening 1997;4(3):152-7.

Alexander FE, Brown HK, Prescott RJ. Improved classification of socio-economic status explains differences in all-cause mortality in the randomised trial of breast cancer screening. Journal of Epidemiology and Biostatistics 1998;3(2):219-24.

Alexander FE, O'Brien F, Hepburn W, Miller M. Association between mortality among women and socioeconomic factors in general practices in Edinburgh: an application of small area statistics. BMJ 1987;295(6601):754-6.

Alexander FE, Roberts MM, Huggins A, Muir BB. Use of risk factors to allocate schedules for breast cancer screening. Journal of Epidemiology and Community Health 1988;42(2):193-9.

Anderson TJ, Lamb J, Alexander F, Lutz W, Chetty U, Forrest AP, et al. Comparative pathology of prevalent and incident cancers detected by breast screening. Edinburgh Breast Screening Project. The Lancet 1986;1(8480):519-23.

Anderson TJ, Lamb J, Donnan P, Alexander FE, Huggins A, Muir BB, et al. Comparative pathology of breast cancer in a randomised trial of screening. British Journal of Cancer 1991;64(1):108-13.

Benjamin DJ. The efficacy of surgical treatment of breast cancer. Medical Hypotheses 1996;47(5):389-97.

Chamberlain J, Atkinson AB, Cochrane AL. Trial of early detection of breast cancer: Description of method. British Journal of Cancer 1981;44:618-27.

Chamberlain J, Coleman D, Ellamn R, Moss S. Progress report of the UK trial of early detection of breast cancer. In: Day NE, Miller $A B$ editor(s). Progress report of the UK trial of early detection of breast cancer. Toronto: Hans Huber, 1988:45-9.

Chamberlain J, Coleman D, Ellman R, Moss S, Thomas B, Price J. Sensitivity and specificity of screening in the UK trial of early detection of breast cancer. In: Miller AB, Chamberlain J, Day $\mathrm{NE}$, et al. editor(s). Cancer Screening. Cambridge: Cambridge University Press, 1991:3-17.

Chetty U, Wang CC, Forrest AP, Roberts MM. Benign breast disease and cancer. The British Journal of Surgery 1980;67(11):789-90.

Dean C, Roberts MM, French K, Robinson S. Psychiatric morbidity after screening for breast cancer. Journal of Epidemiology and Community Health 1986;40(1):71-5.

French K, Porter AM, Robinson SE, McCallum FM, Howie JG, Roberts MM. Attendance at a breast screening clinic: a problem of administration or attitudes. BMJ 1982;285(6342):617-20.

Milne L. Mammography in the Edinburgh breast screening project. Radiography 1979;45(536):176-8.

Nicholson S, Farndon JR. Edinburgh trial of screening for breast cancer [letter]. The Lancet 1990;335(8700):1290-1.

Owen AW, Forrest AP, Anderson TJ, Samuel E, Young GB, Scott AM. Breast screening and surgical problems. The British Journal of Surgery 1977;64(10):725-8.

Roberts MM, Alexander FE, Anderson TJ, Chetty U, Donnan PT, Forrest $\mathrm{P}$, et al. Edinburgh trial of screening for breast cancer: mortality at seven years. The Lancet 1990;335(8684):241-6.

Roberts MM, Alexander FE, Anderson TJ, Forrest AP, Hepburn W, Huggins $A$, et al. The Edinburgh randomised trial of screening 
for breast cancer: description of method. British Journal of Cancer 1984;50(1):1-6.

Screening for breast cancer. Report from Edinburgh Breast Screening Clinic. BMJ 1978;2(6131):175-8.

UK Trial of Early Detection of Breast Cancer Group. 16-year mortality from breast cancer in the UK Trial of Early Detection of Breast Cancer. The Lancet 1999;353(9168):1909-14.

UK Trial of Early Detection of Breast Cancer Group. First results on mortality reduction in the UK Trial of Early Detection of Breast Cancer. The Lancet 1988;2(8608):411-6.

Wald NJ, Murphy P, Major P, Parkes C, Townsend J, Frost C. UKCCCR multicentre randomised controlled trial of one and two view mammography in breast cancer screening. $B M J$ 1995;311(7014):1189-93.

\section{Göteborg 1982 \{published data only\}}

Bjurstam N, Björneld L, Warwick J, Sala E, Duffy SW, Nyström L. The Gothenburg Breast Screening Trial. Cancer 2003;97:2387-96.

* Nyström L, Andersson I, Bjurstam N, Frisell J, Nordenskjöld B, Rutqvist LE. Long-term effects of mammography screening: updated overview of the Swedish randomised trials. The Lancet 2002;359(9310):909-19.

\section{Göteborg 1982a \{published data only\}}

Bjurstam N, Bjorneld L, Duffy SW, Smith TC, Cahlin E, Erikson O, et al. The Gothenburg Breast Cancer Screening Trial: preliminary results on breast cancer mortality for women aged 39-49. Journal of the National Cancer Institute. Monographs 1997;22:53-5.

Bjurstam N, Bjorneld L, Duffy SW, Smith TC, Cahlin E, Eriksson $\mathrm{O}$, et al. The Gothenburg breast screening trial: first results on mortality, incidence, and mode of detection for women ages 39-49 years at randomization. Cancer 1997;80(11):2091-9.

Bjurstam N, Björneld L, Duffy SW. The Gothenborg breast screening trial: results from 11 years followup. NIH Consensus Development Conference on Breast Cancer Screening for Women Ages 40-49. National Institutes of Health. 1997:63-4.

Bjurstam N, Björneld L, Duffy SW, Prevost TC. Author Reply. Cancer 1998;83(1):188-90.

Miller AB, Baines CJ, To T. The Gothenburg breast screening trial: first results on mortality, incidence, and mode of detection for women ages 39-49 years at randomization [letter]. Cancer 1998;83(1):186-90.

\section{Göteborg 1982b \{published data only\}}

* Nyström L, Rutqvist LE, Wall S, Lindgren A, Lindqvist M, Ryden S, et al. Breast cancer screening with mammography: overview of Swedish randomised trials. The Lancet 1993;341(8851):973-8.
Kopparberg 1977 \{published data only\}

Bergkvist L, Tabar L, Bergstrom R, Adami HO. Epidemiologic determinants of the mammographic parenchymal pattern.

A population-based study within a mammographic screening program. American Journal of Epidemiology 1987;126(6):1075-81.

Tabar L, Chen HH, Duffy SW, Krusemo UB. Primary and adjuvant therapy, prognostic factors and survival in 1053 breast cancers diagnosed in a trial of mammography screening. Japanese Journal of Clinical Oncology 1999;29(12):608-16.

Tabar L, Duffy SW, Krusemo UB. Detection method, tumour size and node metastases in breast cancers diagnosed during a trial of breast cancer screening. European Journal of Cancer \& Clinical Oncology 1987;23(7):959-62.

Tabar L, Gad A. Screening for breast cancer: the Swedish trial. Radiology 1981;138(1):219-22.

Tabar L, Gad A, Holmberg L, Ljungquist U. Significant reduction in advanced breast cancer. Results of the first seven years of mammography screening in Kopparberg, Sweden. Diagnostic Imaging in Clinical Medicine 1985;54(3-4):158-64.

\section{Malmö 1976 \{published data only\}}

Andersson I. Mammographic screening for breast carcinoma [thesis]. University of Lund, 1980.

Andersson I. Personal communication 10 Oct 2000.

Andersson I. Personal communication 12 Feb 2001.

Andersson I. Personal communication 15 June 2001

Andersson I. Personal communication 21 June 1999

Andersson I. Breast cancer screening in Malmo. Recent Results in Cancer Research 1984;90:114-6.

Andersson I. Detection bias in mammographic screening for breast carcinoma. Recent Results in Cancer Research 1984;90:164-5.

Andersson I. Radiographic screening for breast carcinoma. I. Program and primary findings in 45-69 year old women. Acta Radiologica: Diagnosis 1981;22(2):185-94.

Andersson I. Radiographic screening for breast carcinoma. II. Prognostic considerations on the basis of a short-term followup. Acta Radiologica: Diagnosis 1981;22(3A):227-33.

Andersson I. Radiographic screening for breast carcinoma. III. Appearance of carcinoma and number of projections to be used at screening. Acta Radiologica: Diagnosis 1981;22(4):407-20.

Andersson I. Överskattning av besparingar genom screening med mammografi [letter]. Läkartidningen 1996;93(32-33):2725.

Andersson I, Andren L, Hildell J, Linell F, Ljungqvist U, Pettersson $\mathrm{H}$. Breast cancer screening with mammography: a population-based, randomized trial with mammography as the only screening mode. Radiology 1979;132(2):273-6. 
Andersson I, Aspegren K, Janzon L, Landberg T, Lindholm K, Linell F, et al. Mammographic screening and mortality from breast cancer: the Malmo mammographic screening trial. $B M J$ 1988;297(6654):943-8.

Andersson I, Hellstrom L, Bjurstam N, Lundgren B, Fagerberg G, Tabar L. Bröstcancerscreening med mammografi i Sverige. Läkartidningen 1983;80(25):2559-62.

Andersson I, Janzon L. Reduced breast cancer mortality in women under age 50: updated results from the Malmo Mammographic Screening Program. Journal of the National Cancer Institute. Monographs 1997;22:63-7.

Andersson I, Janzon L. Screening with mammography - a critical attitude is supported by new findings. Läkartidningen 1988;85(44):3666-9.

Andersson I, Janzon L, Pettersson H. Radiographic patterns of the mammary parenchyma: variation with age at examination and age at first birth. Radiology 1981;138(1):59-62.

Andersson I, Janzon L, Sigfusson BF. Mammographic breast cancer screening - a randomized trial in Malmo, Sweden. Maturitas 1985;7(1):21-9.

Andersson I, Nystrom L. Mammography screening [letter]. Journal of the National Cancer Institute. Monographs 1995;87(16):1263-4.

Andersson I, Sigfusson BF. Screening for breast cancer in Malmo: a randomized trial. Recent Results in Cancer Research 1987;105:62-6.

Garne JP, Aspegren K, Balldin G, Ranstam J. Increasing incidence of and declining mortality from breast carcinoma. Trends in Malmo, Sweden, 1961-1992. Cancer 1997;79(1):69-74.

Gullberg B, Andersson I, Janzon L, Ranstam J. Screening mammography [letter]. The Lancet 1991;337(8735):244.

Ikeda DM, Andersson I, Wattsgard C, Janzon L, Linell F. Interval carcinomas in the Malmo Mammographic Screening Trial: radiographic appearance and prognostic considerations. AJR. American Journal of Roentgenology 1992;159(2):287-94.

Janzon L, Andersson I. The Malmö mammographic screening trial. In: Miller AB, Chamberlain J, Day NE, et al. editor(s). Cancer Screening. Cambridge: Cambridge University Press, 1991:37-44.

Ringberg A, Andersson I, Aspegren K, Linell F. Breast carcinoma in situ in 167 women-incidence, mode of presentation, therapy and follow-up. European Journal of Surgical Oncology 1991;17(5):466-76.

\section{Malmö II 1978 \{published data only\}}

* Andersson I, Janzon L. Reduced breast cancer mortality in women under age 50: updated results from the Malmo Mammographic Screening Program. Journal of the National Cancer Institute. Monographs 1997;22:63-7.

\section{New York 1963 \{published data only\}}

Aron JL, Prorok PC. An analysis of the mortality effect in a breast cancer screening study. Journal of the National Cancer Institute. Monographs 1986;15:36-43.

Chu KC, Connor RJ. Analysis of the temporal patterns of benefits in the Health Insurance Plan of Greater New York trial by stage and age. American Journal of Epidemiology 1991;133(10):1039-49.

Chu KC, Smart CR, Tarone RE. Analysis of breast cancer mortality and stage distribution by age for the Health Insurance Plan clinical trial. Journal of the National Cancer Institute 1988;80(14):1125-32.

Connor RJ, Prorok PC, Weed DL. The case-control design and the assessment of the efficacy of cancer screening. Journal of Clinical Epidemiology 1991;44(11):1215-21.

Final reports of National Cancer Institute ad hoc working groups on mammography screening for breast cancer and a summary report of their joint findings and recommendations. DHEW Publication No. (NIH) 77 1400. US Department of Health, Education and Welfare, 1977.

Fink R, Shapiro S. Significance of increased efforts to gain participation in screening for breast cancer. American Journal of Preventive Medicine 1990;6(1):34-41.

Fink R, Shapiro S, Lewison J. The reluctant participant in a breast cancer screening program. Public Health Reports 1968;83(6):479-90.

Fink R, Shapiro S, Roester R. Impact of efforts to increase participation in repetitive screenings for early breast cancer detection. American Journal of Public Health 1972;62(3):328-36.

Friedman DR, Dubin N. Case-control evaluation of breast cancer screening efficacy. American Journal of Epidemiology 1991;133(10):974-84.

Habbema JD, van Oortmarssen GJ, van Putten DJ. An analysis of survival differences between clinically and screen-detected cancer patients. Statistics in Medicine 1983;2(2):279-85.

Habbema JD, van Oortmarssen GJ, van Putten DJ, Lubbe JT, van der Maas PJ. Age-specific reduction in breast cancer mortality by screening: an analysis of the results of the Health Insurance Plan of Greater New York study. American Journal of Epidemiology 1986;77(2):317-20.

Shapiro S. Determining the efficacy of breast cancer screening. Cancer 1989;63(10):1873-80.

Shapiro S. Evaluation of two contrasting types of screening programs. Preventive Medicine 1973;2(2):266-77.

Shapiro S. Evidence on screening for breast cancer from a randomized trial. Cancer 1977;39(6 Suppl):2772-82.

Shapiro S. Periodic screening for breast cancer: the HIP Randomized Controlled Trial. Health Insurance Plan. Journal of the National Cancer Institute. Monographs 1997;22:27-30. 
Shapiro S. Screening: assessment of current studies. Cancer 1994;74 Suppl(1):231-8.

Shapiro S. The status of breast cancer screening: a quarter of a century of research. World Journal of Surgery 1989;13(1):9-18.

Shapiro S, Goldberg JD, Hutchison GB. Lead time in breast cancer detection and implications for periodicity of screening. American Journal of Epidemiology 1974;100(5):357-66.

Shapiro S, Strax P, Venet L. Evaluation of periodic breast cancer screening with mammography. Methodology and early observations. JAMA 1966;195(9):731-8.

Shapiro S, Strax P, Venet L. Evaluation of periodic breast cancer screening with mammography: methodology and early observations. 1966 [classical article]. CA: A Cancer Journal for Clinicians 1990;40(2):111-25.

Shapiro S, Strax P, Venet L. Periodic breast cancer screening in reducing mortality from breast cancer. JAMA 1971;215(11):1777-85.

Shapiro S, Strax P, Venet L, Fink R. The search for risk factors in breast cancer. American Journal of Public Health and the Nation's Health 1968;58(5):820-35.

Shapiro S, Strax P, Venet L, Venet W. Changes in 5-year breast cancer mortality in a breast cancer screening program. Proceedings. National Cancer Conference 1972;7:663-78.

Shapiro S, Venet W, Strax P, Venet L. Periodic screening for breast cancer: The health insurance plan project and its sequelae, 1963-1986. Baltimore: Johns Hopkins University Press, 1988:The health insurance plan project and its sequelae.

Shapiro S, Venet W, Strax P, Venet L. Current results of the breast cancer screening randomized trial: The health insurance plan (HIP) of greater New York study. In: Day NE, Miller AB editor(s). Screening for breast cancer. Toronto: Hans Huber, 1988:3-15.

Shapiro S, Venet W, Strax P, Venet L, Roeser R. Prospects for eliminating racial differences in breast cancer survival rates. American Journal of Public Health 1982;72(10):1142-5.

Shapiro S, Venet W, Strax P, Venet L, Roeser R. Selection, follow-up, and analysis in the Health Insurance Plan Study: a randomized trial with breast cancer screening. Journal of the National Cancer Institute. Monographs 1985;67:65-74.

Shapiro S, Venet W, Strax P, Venet L, Roeser R. Ten- to fourteenyear effect of screening on breast cancer mortality. Journal of the National Cancer Institute 1982;69(2):349-55.

Smart CR. Highlights of the evidence of benefit for women aged 40-49 years from the 14-year follow-up of the Breast Cancer Detection Demonstration Project. Cancer 1994;74(1 Suppl):296-300.

Strax P. Advances in detection of early breast cancer. Cancer Detection and Prevention 1983;6(4-5):409-14.

Strax P. Benefit of breast cancer screening on morbidity and mortality. In: Bostrom H, et al. editor(s). Health control in detection of cancer. Stockholm: Almqvist and Wiksell, 1976:133-45.

Strax P. Mass screening for control of breast cancer. Cancer 1984;53(3 Suppl):665-70.

Strax P. Physical methods in breast cancer diagnosis. Israel Journal of Medical Sciences 1981;17(9-10):847-53.

Strax P, Venet L, Shapiro S. Mass screening in mammary cancer. Cancer 1969;23(4):875-8.

Strax $\mathrm{P}$, Venet $\mathrm{L}$, Shapiro $\mathrm{S}$. Value of mammography in reduction of mortality from breast cancer in mass screening. The American Journal of Roentgenology, Radium Therapy, and Nuclear Medicine 1973;117(3):686-9.

Strax P, Venet L, Shapiro S, Gross S. Mammography and clinical examination in mass screening for cancer of the breast. Cancer 1967;20(12):2184-8.

Strax P, Venet L, Shapiro S, Gross S, Venet W. Breast cancer found on repetitive examination in mass screening. Archives of Environmental Health 1970;20(6):758-63.

Thomas LB, Ackerman LV, McDivitt RW, Hanson TAS, Hankey BF, Prorok PC. Report of $\mathrm{NCl}$ ad hoc pathology working group to review the gross and microscopic findings of breast cancer cases in the HIP study. Journal of the National Cancer Institute 1977;59(2):496-541.

\section{Östergötland 1978 \{published data only\}}

Arnesson LG, Fagerberg G, Grontoft O, Lundstrom B. Surgical biopsy of non-palpable mammary lesions. Technique and results. Acta Chirurgica Scandinavica 1986;152:97-101.

Arnesson LG, Smeds S, Fagerberg G. Recurrence-free survival in patients with small breast cancer. An analysis of cancers 10 $\mathrm{mm}$ or less detected clinically and by screening. The European Journal of Surgery 1994;160(5):271-6.

Arnesson LG, Smeds S, Fagerberg G, Grontoft O. Follow-up of two treatment modalities for ductal cancer in situ of the breast. The British Journal of Surgery 1989;76(7):672-5.

Arnesson LG, Smeds S, Hatschek T, Nordenskjold B, Fagerberg G. Hormone receptors, ploidy and proliferation rate in breast cancers up to $10 \mathrm{~mm}$. European Journal of Surgical Oncology 1992;18(3):235-40.

Arnesson LG, Vitak B, Manson JC, Fagerberg G, Smeds S. Diagnostic outcome of repeated mammography screening. World Journal of Surgery 1995;19(3):372-7.

Fagerberg G. Experience from randomized controlled breast screening with mammography in Ostergotland county, Sweden: a preliminary report. Recent Results in Cancer Research 1984;90:117.

Fagerberg G, Baldetorp L, Grontoft O, Lundstrom B, Manson JC, Nordenskjold B. Effects of repeated mammographic screening on breast cancer stage distribution. Results from a randomised study of 92934 women in a Swedish county. Acta Chirurgica Scandinavica 1985;24(6):465-73. 
Hatschek T, Carstensen J, Fagerberg G, Stal O, Grontoft O, Nordenskjold B. Influence of S-phase fraction on metastatic pattern and post-recurrence survival in a randomized mammography screening trial. Breast Cancer Research and Treatment 1989;14(3):321-7.

Hatschek T, Fagerberg G, Stal O, Sullivan S, Carstensen J, Grontoft O, et al. Cytometric characterization and clinical course of breast cancer diagnosed in a population-based screening program. Cancer 1989;64(5):1074-81.

Hatschek T, Grontoft O, Fagerberg G, Stal O, Sullivan S, Carstensen J, et al. Cytometric and histopathologic features of tumors detected in a randomized mammography screening program: correlation and relative prognostic influence. Breast Cancer Research and Treatment 1990;15(3):149-60.

Lundström B, Fagerberg G. Clinical problems in relation to breast cancer screening with mammography. A preliminary report. Acta Chirurgica Scandinavica. Supplementum 1984;519:61-3.

Vitak B. Invasive interval cancers in the Ostergotland Mammographic Screening Programme: radiological analysis. European Radiology 1998;8(4):639-46.

\section{Stockholm 1981 \{published data only\}}

Frisell J. Mammographic screening for breast cancer [thesis]. Stockholm: Södersjukhuset, 1989. [ISBN: 91-7900-659-0]

Frisell J. Personal communication 13 Nov 2000.

Frisell J. Personal communication 16 Nov 2000.

Frisell J, Eklund G, Hellstrom L, Glas U, Somell A. The Stockholm breast cancer screening trial - 5-year results and stage at discovery. Breast Cancer Research and Treatment 1989;13(1):79-87.

Frisell J, Eklund G, Hellstrom L, Lidbrink E, Rutqvist LE, Somell A. Randomized study of mammography screening preliminary report on mortality in the Stockholm trial. Breast Cancer Research and Treatment 1991;18(1):49-56.

Frisell J, Eklund G, Hellstrom L, Somell A. Analysis of interval breast carcinomas in a randomized screening trial in Stockholm. Breast Cancer Research and Treatment 1987;9(3):219-25.

Frisell J, Eklund G, Nilsson R, Hellstrom L, Somell A. Additional value of fine-needle aspiration biopsy in a mammographic screening trial. The British Journal of Surgery 1989;76(8):840-3.

Frisell J, Glas U, Hellstrom L, Somell A. Randomized mammographic screening for breast cancer in Stockholm. Design, first round results and comparisons. Breast Cancer Research and Treatment 1986;8(1):45-54.

Frisell J, Lidbrink E. The Stockholm Mammographic Screening Trial: Risks and benefits in age group 40-49 years. Journal of the National Cancer Institute. Monographs 1997;22:49-51.

Frisell J, Lidbrink E, Hellstrom L, Rutqvist LE. Followup after 11 years - update of mortality results in the Stockholm mammographic screening trial. Breast Cancer Research and Treatment 1997;45(3):263-70.

Frisell J, von Rosen A, Wiege M, Nilsson B, Goldman S. Interval cancer and survival in a randomized breast cancer screening trial in Stockholm. Breast Cancer Research and Treatment 1992;24(1):11-6.

Lidbrink E, Elfving J, Frisell J, Jonsson E. Neglected aspects of false positive findings of mammography in breast cancer screening: analysis of false positive cases from the Stockholm trial. BMJ 1996;312(7026):273-6.

Lidbrink E, Frisell J, Brandberg Y, Rosendahl I, Rutqvist LE. Nonattendance in the Stockholm mammography screening trial: relative mortality and reasons for nonattendance. Breast Cancer Research and Treatment 1995;35(3):267-75.

von Rosen A, Frisell J, Glas U, Hellstrom L, Nilsson R, Skoog L, et al. Non-palpable invasive breast carcinomas from the Stockholm screening project. Acta Oncologica (Stockholm, Sweden) 1989;28(1):23-7.

von Rosen A, Frisell J, Nilsson R, Wiege M, Auer G. Histopathologic and cytochemical characteristics of interval breast carcinomas from the Stockholm Mammography Screening Project. Acta Oncologica (Stockholm, Sweden) 1992;31(4):399-402.

\section{Two-County 1977 \{published data only\}}

Summary of the discussion on breast cancer screening. In: Miller AB, Chamberlain J, Day NE, et al. editor(s). Cancer screening. Cambridge: Cambridge University Press, 1991:78-80.

Chen HH, Tabar L, Fagerberg G, Duffy SW. Effect of breast cancer screening after age 65. Journal of Medical Screening 1995;2(1):10-4.

Day NE. Surrogate measures in the design of breast screening trials. In: Miller AB, Chamberlain J, Day NE, et al. editor(s). Cancer Screening. Cambridge: Cambridge University Press, 1991:391-403.

Day NE, Williams DR, Khaw KT. Breast cancer screening programmes: the development of a monitoring and evaluation system. British Journal of Cancer 1989;59(6):954-8.

Duffy S, Tabar L, Krusemo UB, Day N. Randomization by cluster in the Swedish two-county trial: recent results from Kopparberg and implications for interpretation [abstract]. Nordic Cancer Union 1989, Symposium in Stockholm 17-19 Aug 1989.

Duffy SW, Chen HH, Tabar L, Fagerberg G, Paci E. Sojourn time, sensitivity and positive predictive value of mammography screening for breast cancer in women aged 40-49. International Journal of Epidemiology 1996;25(6):1139-45.

Duffy SW, Day NE, Tabar L, Chen HH, Smith TC. Markov models of breast tumor progression: some age-specific results. Journal of the National Cancer Institute. Monographs 1997;22:93-7.

Duffy SW, South MC, Day NE. Cluster randomization in large public health trials: the importance of antecedent data. Statistics in Medicine 1992;11(3):307-16. 
Duffy SW, Tabar L. Screening for breast cancer [letter]. The Lancet 1995;346(8978):852.

Duffy SW, Tabar L, Fagerberg G, Gad A, Grontoft O, South MC, et al. Breast screening, prognostic factors and survival - results from the Swedish two county study. British Journal of Cancer 1991;64(6):1133-8.

Duffy SW, Tabar L, Vitak B, Yen MF, Warwick J, Smith RA, et al. The Swedish Two-County Trial of mammographic screening: cluster randomisation and end point evaluation. Annals of Oncology 2003;14(8):1196-8.

Duffy SW, Tabar L, Vitak B, et al. The Swedish Two-County Trial of mammographic screening: cluster randomisation and end point evaluation. Annals of Oncology 2003;14(8):1196-8.

Fagerberg CJG, Tabar L. The results of periodic one-view mammography screening in a randomized, controlled trial in Sweden. In: Day NE, Miller AB editor(s). Screening for breast cancer. Toronto: Hans Huber, 1988:33-8.

Holmberg L, Adami HO, Lundstrom T, Persson I, Tabar L. [Mass screening mammography results in an increased need for surgical wards]. Läkartidningen 1986;83(22):2047-9.

Holmberg L, Adami HO, Persson I, Lundstrom T, Tabar L. Demands on surgical inpatient services after mass mammographic screening. BMJ 1986;293(6550):779-82.

Holmberg LH, Tabar L, Adami HO, Bergstrom R. Survival in breast cancer diagnosed between mammographic screening examinations. The Lancet 1986;2(8497):27-30.

Nixon R, Prevost TC, Duffy SW, Tabar L, Vitak B, Chen HH. Some random-effects models for the analysis of matched-cluster randomised trials: application to the Swedish two-county trial of breast-cancer screening. Journal of Epidemiology and Biostatistics 2000;5(6):349-58.

Nixon RM, Pharoah P, Tabar L, et al. Mammographic screening in women with a family history of breast cancer: some results from the Swedish two-county trial. Revue D'épidémiologie et de Santé Publique 2000;48(4):325-31.

Projektgruppen för WE-studien i Kopparbergs och Östergötlands län samt socialstyrelsens bearbetningsgrupp för WE-projektet. Reply on mammography [Replik om mammografi]. Läkartidningen 1985;82:2674.

Prorok PC. Personal communication 2 Feb 2000.

Rapport över mammografiscreening i Kopparbergs och Östergötlands läns landsting (WE-projektet) - Resultat efter första screeningsomgången. Unknown. Stockholm: Socialstyrelsen, 1982.

Socialstyrelsens beredningsgrupp för WE-projektet. Minskad mortalitet i bröstcancer genom hälskontroll med mammografi. Nordisk Medicin 1985;100:175-8.

Tabar L. Personal communication 17 Jan 2000.

Tabar L. Mammografins förmåga finna högriskfallen ar nyckelfrågan [letter]. Läkartidningen 1996;93(38):3221.
Tabar L. SBUs aktuella statistik inaktuell [letter]. Läkartidningen 1995;92(48):4540-1.

Tabar L, Akerlund E, Gad A. Five-year experience with singleview mammography randomized controlled screening in Sweden. Recent Results in Cancer Research 1984;90:105-13.

Tabar L, Chen HH, Fagerberg G, Duffy SW, Smith TC. Recent results from the Swedish Two-County Trial: the effects of age, histologic type, and mode of detection on the efficacy of breast cancer screening. Journal of the National Cancer Institute. Monographs 1997;22:43-7.

Tabar L, Duffy SW. Criticisms of Swedish mammography trials were wrong [letter]. BMJ 1999;319:1367.

Tabar L, Duffy SW, Burhenne LW. New Swedish breast cancer detection results for women aged 40-49. Cancer 1993;72 Suppl(4):1437-48.

Tabar L, Duffy SW, Chen HH. Quantitative interpretation of agespecific mortality reductions from the Swedish Breast CancerScreening Trials [letter]. Journal of the National Cancer Institute 1996;88(1):52-5.

Tabar L, Duffy SW, Day NE. Screening with mammography [letter]. International Journal of Technology Assessment in Health Care 1990;6(3):498-500.

Tabar L, Duffy SW, Yen MF, Warwick J, Vitak B, Chen HH, et al. All-cause mortality among breast cancer patients in a screening trial: support for breast cancer mortality as an end point. Journal of Medical Screening 2002;9(4):159-62.

Tabar L, Duffy SW, Yen MF, et al. All-cause mortality among breast cancer patients in a screening trial: support for breast cancer mortality as an end point. Journal of Medical Screening 2002;9(4):159-62.

Tabar L, Faberberg G, Day NE, Holmberg L. What is the optimum interval between mammographic screening examinations? An analysis based on the latest results of the Swedish twocounty breast cancer screening trial. British Journal of Cancer 1987;55(5):547-51.

Tabar L, Fagerberg CJ, Gad A, Baldetorp L, Holmberg LH, Grontoft O, et al. Reduction in mortality from breast cancer after mass screening with mammography. Randomised trial from the Breast Cancer Screening Working Group of the Swedish National Board of Health and Welfare. The Lancet 1985;1(8433):829-32.

Tabar L, Fagerberg CJG, Day NE. The results of periodic oneview mammographic screening in Sweden. Part 2: Evaluation of the results. In: Day NE, Miller AB editor(s). Screening for breast cancer. Toronto: Hans Huber, 1988:39-44.

Tabar L, Fagerberg CJG, South MC, Day NE, Duffy SW. The Swedish Two-county Trial of mammographic screening for breast cancer: recent results on mortality and tumour characteristics. In: Miller AB, Chamberlain J, Day NE, et al. editor(s). Cancer screening. Cambridge University Press: Cambridge University Press, 1991:23-36. 
Tabar L, Fagerberg G, Chen HH, Duffy SW, Gad A. Screening for breast cancer in women aged under 50: mode of detection, incidence, fatality, and histology. Journal of Medical Screening 1995;2(2):94-8.

Tabar L, Fagerberg G, Chen HH, Duffy SW, Gad A. Tumour development, histology and grade of breast cancers: prognosis and progression. International Journal of Cancer 1996;66(4):413-9.

Tabar L, Fagerberg G, Chen HH, Duffy SW, Smart CR, Gad A, et al. Efficacy of breast cancer screening by age. New results from the Swedish Two-County Trial. Cancer 1995;75(10):2507-17.

Tabar L, Fagerberg G, Day NE, Duffy SW. The Swedish twocounty trial of mammographic screening for breast cancer: recent results on mortality and tumor characteristics. Pathologie-Biologie 1992;39(9):846.

Tabar L, Fagerberg G, Day NE, Duffy SW, Kitchin RM. Breast cancer treatment and natural history: new insights from results of screening. The Lancet 1992;339(8790):412-4.

Tabar L, Fagerberg G, Duffy SW, Day NE. Mammografi minskar dödligheten i bröstcancer signifikant. Läkartidningen 1990;87(1-2):36-9.

Tabar L, Fagerberg G, Duffy SW, Day NE. The Swedish two county trial of mammographic screening for breast cancer: recent results and calculation of benefit. Journal of Epidemiology and Community Health 1989;43(2):107-14.

Tabar L, Fagerberg G, Duffy SW, Day NE, Gad A, Grontoft O. Update of the Swedish two-county program of mammographic screening for breast cancer. Radiologic Clinics of North America 1992;30(1):187-210.

Tabar L, Gad A, Akerlund E, Fors B, Fagerberg G, Baldetorp L. Screening for breast cancer in Sweden. A randomised controlled trial. In: Logan WW, Muntz EP editor(s). Reduced dose mammography. New York: Masson, 1979:407-14.

Tabar L, Smith RA, Vitak B, et al. Mammographic screening: a key factor in the control of breast cancer. Cancer Journal (Sudbury, Mass.) 2003;9(1):15-27.

Tabar L, Vitak B, Chen HH, et al. The Swedish Two-County Trial twenty years later. Updated mortality results and new insights from long-term follow-up. Radiologic Clinics of North America 2000;38(4):625-51.

Tabar L, Vitak B, Chen HH, Prevost TC, Duffy SW. Update of the Swedish Two-County Trial of breast cancer screening: histologic grade-specific and age-specific results. Swiss Surgery 1999;5(5):199-204.

Tabar L, Vitak B, Yen MF, Chen HH, Smith RA, Duffy SW. Number needed to screen: lives saved over 20 years of follow-up in mammographic screening. Journal of Medical Screening 2004;11(3):126-9.

Warwick J, Tabar L, Vitak B, Duffy SW. Time-dependent effects on survival in breast carcinoma: results of 20 years of follow-up from the Swedish Two-County Study. Cancer 2004;100(7):1331-6.

\section{UK age trial 1991 \{published data only\}}

Johns LE, Moss SM. False-positive results in the randomized controlled trial of mammographic screening from age 40 ("Age" trial). Cancer Epidemiology Biomarkers and Prevention 2010;19:2758-64.

Johns LE, Moss SM. Randomized controlled trial of mammographic screening from age 40 ('Age' trial): patterns of screening attendance. J Med Screen 2010; 17(1):37-43.. Journal of Medical Screening 2010;17:37-43.

Moss S. A trial to study the effect on breast cancer mortality of annual mammographic screening in women starting at age 40. Trial Steering Group. Journal of Medical Screening 1999;6(3):144-8.

Moss S, Thomas I, Evans A, Thomas B, Johns L. Randomised controlled trial of mammographic screening in women from age 40: results of screening in the first 10 years. British Journal of Cancer 2005;92:949-54.

Moss S, Waller M, Anderson TJ, Cuckle H. Randomised controlled trial of mammographic screening in women from age 40: predicted mortality based on surrogate outcome measures. British Journal of Cancer 2005;92:955-60.

Moss SM, Cuckle H, Evans A, Johns L, Waller M, Bobrow L, for the Trial Management Group. Effect of mammographic screening from age 40 years on breast cancer mortality at 10 years' followup: a randomised controlled trial. The Lancet 2006;368:2053-60.

\section{References to studies excluded from this review}

\section{Berglund 2000 \{published data only\}}

* Berglund G, Nilsson P, Eriksson K F, Nilsson J A, Hedblad B, Kristenson $\mathrm{H}$, et al. Long-term outcome of the Malmo preventive project: mortality and cardiovascular morbidity. Journal of Internal Medicine 2000;247:19-29.

\section{Dales 1979 \{published data only\}}

Dales LG, Friedman GD, Collen MF. Evaluating periodic multiphasic health checkups: a controlled trial. Journal of Chronic Diseases 1979;32:385-404.

\section{Singapore 1994 \{published data only\}}

Ng EH, Ng FC, Tan PH, Low SC, Chiang G, Tan KP, et al. Results of intermediate measures from a population-based, randomized trial of mammographic screening prevalence and detection of breast carcinoma among Asian women: the Singapore Breast Screening Project. Cancer 1998;82(8):1521-8.

\section{Additional references}

\section{Alexander 1989}

Alexander F, Roberts MM, Lutz W, Hepburn W. Randomisation by cluster and the problem of social class bias. Journal of Epidemiology and Community Health 1989;43(1):29-36. 


\section{Alexander 1994}

Alexander FE, Anderson TJ, Brown HK, Forrest AP, Hepburn W, Kirkpatrick AE, et al. The Edinburgh randomised trial of breast cancer screening: results after 10 years of follow-up. British Journal of Cancer 1994;70(3):542-8.

\section{Alexander 1999}

Alexander FE, Anderson TJ, Brown HK, Forrest AP, Hepburn W, Kirkpatrick $A E$, et al. 14 years of follow-up from the Edinburgh randomised trial of breast-cancer screening. The Lancet 1999;353(9168):1903-8.

\section{Alexander 2000}

Alexander F. Personal communication 3 Oct 2000.

\section{Andersson 1980}

Andersson I. Mammographic screening for breast carcinoma [thesis]. University of Lund, 1980.

\section{Andersson 1981}

Andersson I. Radiographic screening for breast carcinoma. I. Program and primary findings in 45-69 year old women. Acta Radiologica: Diagnosis 1981;22(2):185-94.

\section{Andersson 1981a}

Andersson I. Radiographic screening for breast carcinoma. II. Prognostic considerations on the basis of a short-term followup. Acta Radiologica: Diagnosis 1981;22(3A):227-33.

\section{Andersson 1983}

Andersson I, Hellstrom L, Bjurstam N, Lundgren B, Fagerberg G, Tabar L. Bröstcancerscreening med mammografi i Sverige. Läkartidningen 1983;80(25):2559-62.

\section{Andersson 1988}

Andersson I, Aspegren K, Janzon L, Landberg T, Lindholm K, Linell $F$, et al. Mammographic screening and mortality from breast cancer: the Malmo mammographic screening trial. $B M J$ 1988;297(6654):943-8.

\section{Andersson 1988a}

Andersson I, Janzon L. Mammografi för screening - kritisk inställning stöds av nya fynd [Screening with mammography a critical attitude is supported by new findings]. Läkartidningen 1988;85(44):3666-9.

\section{Andersson 1997}

Andersson I, Janzon L. Reduced breast cancer mortality in women under age 50: updated results from the Malmo Mammographic Screening Program. Journal of the National Cancer Institute 1997;22:63-7.

\section{Andersson 1999a}

Anderssson I. Personal communication 15 June 1999.

\section{Andersson 1999b}

Andersson I. Personal communication 21 June 1999.

\section{Andersson 2000}

Andersson I. Personal communication 10 Oct 2000.

\section{Andersson 2001}

Andersson I. Personal communication 12 Feb 2001.

\section{Armstrong 2007}

Armstrong K, Moye E, Williams S, Berlin JA, Reynolds EE. Screeningmammography in women 40 to 49 years of age: a systematic review for the American College of Physicians. Annals of Internal Medicine 2007;146:516-26.

\section{Arnesson 1995}

Arnesson LG, Vitak B, Manson JC, Fagerberg G, Smeds S. Diagnostic outcome of repeated mammography screening. World Journal of Surgery 1995;19(3):372-7.

\section{Aron 1986}

Aron J, Prorok PC. An analysis of the mortality effect in a breast cancer screening study. International Journal of Epidemiology 1986;15:36-43.

\section{Atterstam 1999}

Atterstam I. Nil [Ohederliga arbetsmetoder undergräver mammografiresultat]. Svenska Dagbladet 1999, 21. juli; Vol. sect 1:6.

\section{Autier 2010}

Autier P, Boniol M, LaVecchia C, Vatten L, Gavin A, Hery C, et al. Disparities in breast cancer mortality trends between 30 European countries: retrospective trend analysis of WHO mortality database. BMJ 2010;341:c3620.

\section{Autier 2011}

Autier P, Boniol M, Middleton R, Doré JF, Héry C, Zheng T, et al. Advanced breast cancer incidence following population based mammographic screening. Annals of Oncology 2011;22(8):1726-35.

\section{Autier 2011a}

Autier P, Boniol M, Gavin A, Vatten LJ. Breast cancer mortality in neighbouring European countries with different levels of screening but similar access to treatment: trend analysis of WHO mortality database. BMJ 2011;343:d4411.

\section{Bailar 1997}

Bailar JC 3rd, MacMahon B. Randomization in the Canadian National Breast Screening Study: a review for evidence of subversion. Canadian Medical Association Journal 1997;156(2):193-9.

\section{Baines 1994}

Baines CJ. The Canadian National Breast Screening Study: a perspective on criticisms. Annals of Internal Medicine 1994;120(4):326-34.

\section{Baines 1995}

Baines CJ. The Canadian National Breast Screening Study. Why? What next? And so what?. Cancer 1995;76 Suppl(10):2107-12.

\section{Baines 1997}

Baines CJ, Miller AB. Mammography versus clinical examination of the breasts. Journal of the National Cancer Institute. Monographs 1997;22:125-9. 


\section{Baines 2001}

Baines CJ. Personal communication 18 Jan 2001.

\section{Baines 2005}

Baines CJ. Personal communication 30 Nov 2005.

\section{Barratt 1997}

Barratt AL, Cockburn J, Redman S, Paul C, Perkins J. Mammographic screening: results from the 1996 National Breast Health Survey. The Medical Journal of Australia 1997;167:521-4.

\section{Barratt 1999}

Barratt A, Cockburn J, Furnival C, McBride A, Mallon L. Perceived sensitivity of mammographic screening: women's views on test accuracy and financial compensation for missed cancers. Journal of Epidemiology and Community Health 1999;53:716-20.

\section{Barratt 2005}

Barratt A, Howard K, Irwig L, Salkeld G, Houssami N. Model of outcomes of screening mammography: information to support informed choices. BMJ 2005;330:936-8.

\section{Barton 2001}

Barton MB, Moore S, Polk S, Shtatland E, Elmore JG, Fletcher SW. Increased patient concern after false-positive mammograms: clinician documentation and subsequent ambulatory visits. Journal of General Internal Medicine 2001;16:150-6.

\section{BASO audit 2000}

NHS cancer screening programmes. BASO Breast Audit 1999/2000. www.cancerscreening.nhs.uk/breastscreen/ publications.html (accessed Dec 12, 2001).

\section{Baum 2000}

Baum M, Tobias JS. Investment in treatment would be more effective (letter). BMJ 2000;321:1528.

\section{Benjamin 1996}

Benjamin DJ. The efficacy of surgical treatment of breast cancer. Medical Hypotheses 1996;47(5):389-97.

\section{Berry 1998}

Berry DA. Benefits and risks of screening mammography for women in their forties: a statistical appraisal. Journal of the National Cancer Institute 1998;90:1431-9.

\section{Berry 2002}

Berry DA. The Utility of Mammography for Women 40 to 50 Years of Age (Con). In: DeVita VT, Hellman S, Rosenberg SAe editor(s). Progress in Oncology. Sudbury: Jones and Bartlett, 2002:346-72.

\section{Berry 2005}

Berry DA, Cronin KA, Plevritis SK, Fryback DG, Clarke L, Zelen $\mathrm{M}$, et al. Effect of screening and adjuvant therapy on mortality from breast cancer. New England Journal of Medicine 2005;353:1784-92.

\section{Bjurstam 1997}

Bjurstam N, Bjorneld L, Duffy SW, Smith TC, Cahlin E, Eriksson $\mathrm{O}$, et al. The Gothenburg breast screening trial: first results on mortality, incidence, and mode of detection for women ages 39-49 years at randomization. Cancer 1997;80(11):2091-9.

\section{Bjurstam 2000}

Bjurstam N. Personal communication 10 Oct 2000.

\section{Bjurstam 2003}

Bjurstam N, Björneld L, Warwick J, Sala E, Duffy SW, Nyström L. The Gothenburg Breast Screening Trial. Cancer 2003;97:2387-96

\section{Blamey 2000}

Blamey RW, Wilson ARM, Patnick J. ABC of breast diseases: screening for breast cancer. BMJ 2000;321:689-93.

\section{Blamey 2007}

Blamey RW, Ellis IO, Pinder SE, Lee AHS, Macmillan RD, Morgan DAL, et al. Survival of invasive breast cancer according to the Nottingham Prognostic Index in cases diagnosed in 1990-1999. European Journal of Cancer 2007;43:1548-55.

\section{Bleyer 2011}

Bleyer A. US breast cancer mortality is consistent with European data. BMJ 2011;343:d5630.

\section{Bleyer 2012}

Bleyer A, Welch HG. Effect of three decades of screening mammography on breast-cancer incidence. New England Journal of Medicine 2012;367:1998-2005.

\section{Brett 2001}

Brett J, Austoker J. Women who are recalled for further investigation for breast screening: psychological consequences 3 years after recall and factors affecting re-attendance. Journal of Public Health Medicine 2001;23(4):292-300.

\section{Brodersen 2006}

Brodersen J. Measuring psychosocial consequences of falsepositive screening results - breast cancer as an example (PhD thesis). Institute of Public Health, Faculty of Health Sciences, Department of General Practice, University of Copenhagen. (http://cms.ku.dk/sund-sites/ifsv-sites/ifsv-inst/ominstituttet/ afdelinger/almen_medicin/medarbejdere/publicationdetail/? id=1109837) 2006.

\section{Brodersen 2007}

Brodersen J, Thorsen H, Kreiner S. Validation of a conditionspecific measure for women having an abnormal screening mammography. Value in Health 2007;10:294-304.

\section{Brodersen 2013}

Brodersen J, Siersma V. Long-term psychosocial consequences of false-positive screening mammography - a cohort study with 3-year follow-up. Annals of Family Medicine 2013;11(2):106-15. 


\section{Brown 1993}

Brown BW, Brauner C, Minnotte MC. Noncancer deaths in white adult cancer patients. Journal of the National Cancer Institute 1993;85(12):979-87.

\section{Burton 2011}

Burton RC, Bell RJ, Thiagarajah G, Stevenson C. Adjuvant therapy, not mammographic screening, accounts for most of the observed breast cancer specific mortality reductions in Australian women since the national screening program began in 1991. Breast Cancer Research and Treatment 2012;131(3):949-55.

\section{Bülow 2000}

Bülow B von. Psykologiske følger af screening for brystkræft blandt raske kvinder. Ugeskrift for Laeger 2000;162:1053-9.

\section{Castells 2006}

Castells X, Molins E, Macia F. Cumulative false positive recall rate and association with participant related factors in a population based breast cancer screening programme. Journal of Epidemiology and Community Health 2006;60:316-21.

\section{Chamberlain 1981}

Chamberlain J, Atkinson AB, Cochrane AL. Trial of early detection of breast cancer: Description of method. British Journal of Cancer 1981;44:618-27.

\section{Chlebowski 2009}

Chlebowski RT, Kuller LH, Prentice RL, Stefanick ML, Manson JE, Gass M, et al. Breast cancer after use of estrogen plus progestin in postmenopausal women. New England Journal of Medicine 2009;360:573-87.

\section{Christiansen 2000}

Christiansen CL, Wang F, Barton MB, Kreuter W, Elmore JG, Gelfand AE, Fletcher SW. Predicting the cumulative risk of falsepositive mammograms. Journal of the National Cancer Institute 2000;92:1657-66.

\section{Cox 1997}

Cox B. Variation in the effectiveness of breast screening by year of follow-up. Journal of the National Cancer Institute. Monographs 1997;22:69-72.

\section{Crewdson 2002}

Crewdson J. Swedes doubt mammography trial: disparities found in landmark study. Chicago Tribune 2002; March 15:http:// www.chicagotribune.com/news/chi-0203150264mar15.story (accessed 15 March, 2002).

\section{Dean 2010}

Dean P, Tabár L. Why does vehement opposition to screening come from Denmark, which has one of Europes highest breast cancer mortality rates?. BMJ 2010:http://www.bmj.com/ content/340/bmj.c1241.full/reply\#bmj_el_234798.

\section{Deeks 2003}

Deeks JJ, Dinnes J, D'Amico R, Sowden AJ, Sakarovitch C, Song F, Petticrew M, Altman DG, International Stroke Trial Collaborative Group, European Carotid Surgery Trial
Collaborative Group. Evaluating non-randomised intervention studies. Health Technology Assessment (Winchester, England) 2003;7(27):1-173.

\section{Demissie 1998}

Demissie K, Mills OF, Rhoads GG. Empirical comparison of the results of randomized controlled trials and case-control studies in evaluating the effectiveness of screening mammography. Journal of Clinical Epidemiology 1998;52:81-91.

\section{Dixon 2009}

Dixon JM. Breast screening has increased the number of mastectomies. Breast Cancer Research 2009;11(Suppl 3):S19.

\section{Dixon-Woods 2001}

Dixon-Woods M, Baum M, Kurinczuk JJ. Screening for breast cancer with mammography. The Lancet 2001;358:2167-8.

\section{Doll 1981}

Doll R, Peto R. The causes of cancer: quantitative estimates of avoidable risks of cancer in the United States today. Journal of the National Cancer Institute 1981;66:1191-308.

\section{Domenighetti 2003}

Domenighetti G, D'Avanzo B, Egger M, Berrino F, Perneger T, Mosconi $P$, et al. Women's perception of the benefits of mammography screening: population-based survey in four countries. International Journal of Epidemiology 2003;32:816-21.

\section{Douek 2003}

Douek M, Baum M. Mass breast screening: is there a hidden cost?. The British Journal of Surgery 2003;90 Suppl 1:(Abstract Breast 14).

\section{Duffy 2002}

Duffy SW, Tabár L, Smith RA. The mammographic screening trials: commentary on the recent work by Olsen and Gøtzsche (authors' reply). Journal of Surgical Oncology 2002;81:164-6.

\section{Duffy 2003}

Duffy SW, Tabar L, Vitak B, Yen MF, Warwick J, Smith RA, et al. The Swedish Two-County Trial of mammographic screening: cluster randomisation and end point evaluation. Annals of Oncology 2003;14(8):1196-8.

\section{EBCTCG 1995}

Early Breast Cancer Trialists' Collaborative Group. Effects of radiotherapy and surgery in early breast cancer: An overview of the randomized trials. The New England Journal of Medicine 1995;333:1444-55.

\section{EBCTCG 1998}

Early Breast Cancer Trialists' Collaborative Group. Tamoxifen for early breast cancer: an overview of the randomised trials. The Lancet 1998;35:1451-67.

\section{EBCTCG 2000}

Early Breast Cancer Trialists' Collaborative Group. Favourable and unfavourable effects on long-term survival of radiotherapy 
for early breast cancer: An overview of the randomised trials. The Lancet 2000;355:1757-70.

\section{EBCTCG 2005}

Early Breast Cancer Trialists' Collaborative Group (EBCTCG). Effects of chemotherapy and hormonal therapy for early breast cancer on recurrence and 15-year survival: an overview of the randomised trials. Lancet 2005;365:1687-717.

\section{EBCTCG 2005a}

Early Breast Cancer Trialists' Collaborative Group (EBCTCG). Effects of radiotherapy and of differences in the extent of surgery for early breast cancer on local recurrence and 15year survival: an overview of the randomised trials. Lancet 2005;366:2087-106.

\section{EBCTCG 2012}

Early Breast Cancer Trialists' Collaborative Group (EBCTCG). Comparisons between different polychemotherapy regimens for early breast cancer: meta-analyses of long-term outcome among 100,000 women in 123 randomised trials. Lancet 2012;379:432-44.

\section{Elmore 1998}

Elmore JG, Barton MB, Moceri VM, Polk S, Arena PJ, Fletcher SW. Ten-year risk of false positive screening mammograms and clinical breast examinations. The New England Journal of Medicine 1998;338(16):1089-96.

\section{Elwood 1993}

Elwood JM, Cox B, Richardson AK. The effectiveness of breast cancer screening by mammography in younger women. The Online Journal of Current Clinical Trials [electronic resource] 1993; Vol. Doc No 32.

\section{Elwood 1998}

Elwood M, McNoe B, Smith T, Bandaranayake M. Once is enough - why some women do not continue to participate in a breast screening programme. The New Zealand Medical Journal 1998;111:180-3.

\section{Ernster 1996}

Ernster VL, Barclay J, Kerlikowske K, Grady D, Henderson C. Incidence of and treatment for ductal carcinoma in situ of the breast. JAMA 1996;275(12):913-8.

\section{Ernster 1997}

Ernster VL, Barclay J. Increases in ductal carcinoma in situ (DCIS) of the breast in relation to mammography: a dilemma. Journal of the National Cancer Institute. Monographs 1997;NA(22):151-6.

\section{Esserman 2009}

Esserman L, Shieh Y, Thompson I. Rethinking Screening for Breast Cancer and Prostate Cancer. JAMA 2009;302:1685-92.

\section{Fagerberg 1985}

Fagerberg G, Baldetorp L, Grontoft O, Lundstrom B, Manson JC, Nordenskjold B. Effects of repeated mammographic screening on breast cancer stage distribution. Results from a randomised study of 92934 women in a Swedish county. Acta Radiologica. Oncology 1985;24(6):465-73.

\section{Final reports 1977}

Final reports of National Cancer Institute ad hoc working groups on mammography screening for breast cancer and a summary report of their joint findings and recommendations. DHEW Publication No. (NIH) 77 1400. US Department of Health, Education and Welfare, 1977.

\section{Fink 1972}

Fink R, Shapiro S, Roester R. Impact of efforts to increase participation in repetitive screenings for early breast cancer detection. American Journal of Public Health 1972;62(3):328-36.

\section{Fletcher 1993}

Fletcher SW, Black W, Harris R, Rimer BK, Shapiro S. Report of the International Workshop on Screening for Breast Cancer. Journal of the National Cancer Institute 1993;85(20):1644-56.

\section{Fletcher 2003}

Fletcher SW, Elmore JG. Clinical practice. Mammographic screening for breast cancer. The New England Journal of Medicine 2003;348:1672-80.

\section{Forrest report 1986}

Forrest P, editor. Breast Cancer Screening. Report to the Health Ministers of England, Wales, Scotland \& Northern Ireland. Department of Health and Social Science 1986.

\section{Fox 1979}

Fox MS. On the diagnosis and treatment of breast cancer. JAMA 1979;241(5):489-94.

\section{Freedman 2004}

Freedman DA, Petitti DB, Robins JM. On the efficacy of screening for breast cancer. International Journal of Epidemiology 2004;33:43-55.

\section{Frisell 1986}

Frisell J, Glas U, Hellstrom L, Somell A. Randomized mammographic screening for breast cancer in Stockholm. Design, first round results and comparisons. Breast Cancer Research and Treatment 1986;8(1):45-54.

\section{Frisell 1987}

Frisell J, Eklund G, Hellstrom L, Somell A. Analysis of interval breast carcinomas in a randomized screening trial in Stockholm. Breast Cancer Research and Treatment 1987;9(3):219-25.

\section{Frisell 1989}

Frisell J, Eklund G, Hellstrom L, Glas U, Somell A. The Stockholm breast cancer screening trial - 5-year results and stage at discovery. Breast Cancer Research and Treatment 1989;13(1):79-87.

\section{Frisell 1989a}

Frisell J. Mammographic screening for breast cancer [thesis]. Stockholm: Södersjukhuset, 1989. [ISBN: 91-7900-659-0] 


\section{Frisell 1991}

Frisell J, Eklund G, Hellstrom L, Lidbrink E, Rutqvist LE, Somell A. Randomized study of mammography screening preliminary report on mortality in the Stockholm trial. Breast Cancer Research and Treatment 1991;18(1):49-56.

\section{Frisell 1997}

Frisell J, Lidbrink E, Hellstrom L, Rutqvist LE. Followup after 11 years - update of mortality results in the Stockholm mammographic screening trial. Breast Cancer Research and Treatment 1997;45(3):263-70.

\section{Frisell 2000a}

Frisell J. Personal communication 13 Nov 2000.

\section{Frisell 2000b}

Frisell J. Personal communication 16 Nov 2000.

\section{Fryback 2006}

Fryback DG, Stout NK, Rosenberg MA, Trentham-Dietz A, Kuruchittham V, Remington PL. The Wisconsin Breast Cancer Epidemiology Simulation Model. Journal of the National Cancer Institute Monographs 2006;36:37-47.

\section{Glasziou 1992}

Glasziou PP. Meta-analysis adjusting for compliance: the example of screening for breast cancer. Journal of Clinical Epidemiology 1992;45(11):1251-6.

\section{Glasziou 1995}

Glasziou PP, Woodward AJ, Mahon CM. Mammographic screening trials for women aged under 50 . A quality assessment and meta-analysis. The Medical Journal of Australia 1995;162(12):625-9.

\section{Glasziou 1997}

Glasziou P, Irwig L. The quality and interpretation of mammographic screening trials for women ages 40-49. Journal of the National Cancer Institute. Monographs 1997;22:73-7.

\section{Gram 1990}

Gram IT, Lund E, Slenker SE. Quality of life following a false positive mammogram. Brithis Journal of Cancer 1990;62(6):1018-22.

\section{Gärtner 2009}

Gärtner R, Jensen MB, Nielsen J, Ewertz M, Kroman N, Kehlet H. Prevalence of and factors associated with persistent pain following breast cancer surgery. JAMA 2009;302:1985-92.

\section{Gøtzsche 2000}

Gøtzsche PC, Olsen O. Is screening for breast cancer with mammography justifiable?. The Lancet 2000;355(9198):129-34.

\section{Gøtzsche 2000a}

Gøtzsche PC, Olsen O. Screening mammography re-evaluated [reply]. The Lancet 2000;355:752.

\section{Gøtzsche 2001}

Gøtzsche PC. Screening for breast cancer with mammography. The Lancet 2001;358:2167-8.

\section{Gøtzsche 2002}

Gøtzsche PC. Trends in breast-conserving surgery in the Southeast Netherlands: Comment on article by Ernst and colleagues Eur J Cancer 2001, 37, 2435-2440. European Journal of Cancer 2002;38:1288.

\section{Gøtzsche 2002a}

Gøtzsche PC. Update on effects of screening mammography. Lancet 2002;360:338.

\section{Gøtzsche 2002b}

Gøtzsche PC. Misleading paper on mastectomy rates in a screening programme. BMJ. http://bmj.com/cgi/ eletters/325/7361/418\#24972, 26 Aug 2002.

\section{Gøtzsche 2004}

Gøtzsche PC. On the benefits and harms of screening for breast cancer. International Journal of Epidemiology 2004;33:56-64.

\section{Gøtzsche 2009}

Gøtzsche P, Hartling OJ, Nielsen M, Brodersen J, Jørgensen KJ. Breast screening: the facts - or maybe not. BMJ 2009;338:446-8.

\section{Gøtzsche 2010}

Gøtzsche PC, Jørgensen KJ, Zahl PH. Breast screening: why estimates differ by a factor of 20-25. Journal of Medical Screening 2010;17:158-9.

\section{Gøtzsche 2011}

Gøtzsche PC. Relation between breast cancer mortality and screening effectiveness:systematic review of the mammography trials. Danish Medical Bulletin 2011;58:A4246.

\section{Gøtzsche 2012}

Gøtzsche PC. Mammography screening: truth, lies and controversy. London: Radcliffe, 2012.

\section{Gøtzsche 2012a}

Gøtzsche PC, Jørgensen KJ, Zahl P-H, Mæhlen J. Why mammography screening hasn't lived up to expectations from the randomised trials. Cancer Causes \& Control 2012;23:15-21.

\section{Habbema 1986}

Habbema JD, van Oortmarssen GJ, van Putten DJ, Lubbe JT, van der Maas PJ. Age-specific reduction in breast cancer mortality by screening: an analysis of the results of the Health Insurance Plan of Greater New York study. Journal of the National Cancer Institute 1986;77(2):317-20.

\section{Hendrick 1997}

Hendrick RE, Smith RA, Rutledge JH 3rd, Smart CR. Benefit of screening mammography in women aged 40-49: a new metaanalysis of randomized controlled trials. Journal of the National Cancer Institute. Monographs 1997;22:87-92.

\section{Higgins 2008}

Higgins JPT, Green S (editors). Cochrane Handbook for Systematic Reviews of Interventions Version 5.0.1 [updated September 2008]. Cochrane Handbook for Systematic Reviews of Interventions Version 5.0.1 [updated September 2008]. 
Available from www.cochrane-handbook.org. The Cochrane Collaboration, 2008.

\section{Hofvind 2004}

Hofvind S, Thoresen S, Tretli S. The cumulative risk of a falsepositive recall in the Norwegian Breast Cancer Screening Program. Cancer 2004;101:1501-7.

\section{Holmberg 2009}

Holmberg L, Duffy SW, Yen AM, Tabar L, Vitak B, Nyström L, et al. Differences in endpoints between the Swedish W-E (two county) trial of mammographic screening and the Swedish overview: methodological consequences. Journal of Medical Screening 2009;16:73-80.

\section{Hubbard 2011}

Hubbard RA, Kerlikowske K, Flowers Cl, Yankaskas BC, Zhu W, Miglioretti DL. Cumulative probability of false-positive recall or biopsy recommendation after 10 years of screening mammography: a cohort study. Annals of Internal Medicine 2011;155:481-92.

\section{Humphrey 2002}

Humphrey LL, Helfand M, Chan BK, Woolf SH. Breast cancer screening: a summary of the evidence for the U.S. Preventive Services Task Force. Annals of Internal Medicine 2002;137 (5 Part 1):347-60.

\section{IARC 2002}

Vainio H, Bianchini F, eds. IARC Handbooks of Cancer Prevention. Volume 7. Breast Cancer Screening. Lyon: IARC Press, 2002. [ISBN 92-832-3007-8]

\section{Isacsson 1985}

Isacsson S-O, Larsson L-G, Janzon L. Är dokumentationen verkligen tillräcklig? Forcera inte fram screening utan debatt. Läkartidningen 1985;82(32-33):2672-3.

\section{Janzon 1991}

Janzon L, Andersson I. The Malmö mammographic screening trial. In: Miller AB, Chamberlain J, Day NE, et al. editor(s). Cancer Screening. Cambridge: Cambridge University Press, 1991:37-44.

\section{Johns 2010}

Johns LE, Moss SM. False-positive results in the randomized controlled trial of mammographic screening from age 40 ("Age" trial). Cancer Epidemiology Biomarkers and Prevention 2010;19:2758-64.

\section{Jonsson 2005}

Jonsson $\mathrm{H}$, Johansson R, Lenner P. Increased incidence of invasive breast cancer after the introduction of service screening with mammography in Sweden. International Journal of Cancer 2005;117(5):842-7.

\section{Jørgensen 2004}

Jørgensen KJ, Gøtzsche PC. Presentation on websites of possible benefits and harms from screening for breast cancer: cross sectional study. BMJ 2004;328:148-51.

\section{Jørgensen 2006}

Jørgensen KJ, Gøtzsche PC. Content of invitations for publicly funded screening mammography. BMJ 2006;332:538-41.

\section{Jørgensen 2009}

Jørgensen KJ, Gøtzsche PC. Overdiagnosis in publicly organised mammography screening programmes: systematic review of incidence trends. BMJ 2009;339:b2587.

\section{Jørgensen 2009a}

Jørgensen KJ, Zahl P-H, Gøtzsche PC. Overdiagnosis in organised mammography screening in Denmark: a comparative study. BMC Women's Health 2009;9:36.

\section{Jørgensen 2010}

Jørgensen KJ, Zahl PH, Gøtzsche PC. Breast cancer mortality in organised mammography screening in Denmark. A comparative study. BMJ 2010;340:c1241.

\section{Jørgensen 2011}

Jørgensen KJ, Keen JD, Gøtzsche PC. Is mammographic screening justifiable considering its substantial overdiagnosis rate and minor effect on mortality?. Radiology 2011;260:621-7.

\section{Jørgensen 2012}

Jørgensen KJ. Overdiagnosis of invasive breast cancer due to mammography screening. Annals of Internal Medicine 2012;157:219-20.

\section{Kalager 2010}

Kalager M, Zelen M, Langmark F, Adami HO. Effect of Screening Mammography on Breast-Cancer Mortality in Norway. New England Journal of Medicine 2010;363:1203-10.

\section{Kalager 2012}

Kalager M, Adami HO, Bretthauer M, Tamimi RM. Overdiagnosis of invasive breast cancer due to mammography screening: results from the Norwegian screening program. Annals of Internal Medicine 2012;156:491-9.

\section{Kerlikowske 1995}

Kerlikowske K, Grady D, Rubin SM, Sandrock C, Ernster VL. Efficacy of screening mammography. A meta-analysis. JAMA 1995;273(2):149-54.

\section{Kerlikowske 1997}

Kerlikowske K. Efficacy of screening mammography among women aged 40 to 49 years and 50 to 69 years: comparison of relative and absolute benefit. Journal of the National Cancer Institute. Monographs 1997;22:79-86.

\section{Kricker 2000}

Kricker A, Smoothy V, Armstrong B. Ductal carcinoma in situ in NSW women in 1995 to 1997. National Breast \& Ovarian Cancer Centre, 15 April 2000:www.nbcc.org.au.

\section{Kösters 2003}

Kösters JP, Gøtzsche PC. Regular self-examination or clinical examination for early detection of breast cancer. Cochrane Database of Systematic Reviews 2003, Issue 2. [DOI: 10.1002/14651858.CD003373] 


\section{Larsson 1996}

Larsson LG, Nystrom L, Wall S, Rutqvist L, Andersson I, Bjurstam N, et al. The Swedish randomised mammography screening trials: analysis of their effect on the breast cancer related excess mortality. Journal of Medical Screening 1996;3(3):129-32.

\section{Larsson 1997}

Larsson LG, Andersson I, Bjurstam N, Fagerberg G, Frisell J, Tabar L, et al. Updated overview of the Swedish Randomized Trials on Breast Cancer Screening with Mammography: age group 40-49 at randomization. Journal of the National Cancer Institute. Monographs 1997;22:57-61.

\section{Lerman 1991}

Lerman C, Trock B, Rimer BK, Boyce A, Jepson C, Engstrom PF. Psychological and behavioral implications of abnormal mammograms. Annals of Internal Medicine 1991;114(8):657-61.

\section{Lidbrink 1996}

Lidbrink E, Elfving J, Frisell J, Jonsson E. Neglected aspects of false positive findings of mammography in breast cancer screening: analysis of false positive cases from the Stockholm trial. BMJ 1996;312(7026):273-6.

\section{Malin 2002}

Malin JL, Kahn KL, Adams J, Kwan L, Laouri M, Ganz PA. Validity of cancer registry data for measuring the quality of breast cancer care. Journal of the National Cancer Institute 2002;94(11):835-44.

\section{McNoe 1996}

McNoe B, Miller D, Elwood M. Women's experience of the OtagoSouthland breast screening programme - a compilation of five studies. Hugh Adam Cancer Epidemiology Unit for the Ministry of Health, New Zealand 1996.

\section{McPherson 2009}

McPherson K. Should we screen for breast cancer?. BMJ 2010;340:c3106.

\section{Miller 1992a}

Miller AB, Baines CJ, To T, Wall C. Canadian National Breast Screening Study: 1 . Breast cancer detection and death rates among women aged 40 to 49 years. Canadian Medical Association Journal 1992;147(10):1459-76.

\section{Miller 1992b}

Miller AB, Baines CJ, To T, Wall C. Canadian National Breast Screening Study: 2 . Breast cancer detection and death rates among women aged 50 to 59 years. CMAJ 1992;147(10):1477-88.

\section{Miller 1993}

Miller AB. The costs and benefits of breast cancer screening. American Journal of Preventive Medicine 1993;9(3):175-80.

\section{Miller 1997}

Miller AB, To T, Baines CJ, Wall C. The Canadian National Breast Screening Study: update on breast cancer mortality. Journal of the National Cancer Institute. Monographs 1997;NA(22):37-41.

\section{Miller 1997a}

Miller AB. The Canadian National Breast Screening Study: update on breast cancer mortality. NIH Consensus Development Conference on Breast cancer screening for women ages 40-49. 1997:51-3.

\section{Miller 2000}

Miller AB, To T, Baines CJ, Wall C. Canadian National Breast Screening Study-2: 13-year results of a randomized trial in women aged 50-59 years. Journal of the National Cancer Institute 2000;92:1490-9.

\section{Miller 2001}

Miller AB. Screening for breast cancer with mammography. The Lancet 2001;358:2164.

\section{Miller 2002}

Miller AB, To T, Baines CJ, Wall C. The Canadian National Breast Screening Study-1: breast cancer mortality after 11 to 16 years of follow-up. A randomized screening trial of mammography in women age 40 to 49 years. Annals of Internal Medicine 2002;137(5 Part 1):305-12.

\section{Miller 2002a}

Miller D, Martin I, Herbison P. Interventions for relieving the pain and discomfort of screening mammography. Cochrane Database of Systematic Reviews 2002, Issue 4. [DOI: 10.1002/14651858.CD002942]

\section{Moody-Ayers 2000}

Moody-Ayers SY, Wells CK, Feinstein AR. "Benign" tumors and "early detection" in mammography-screened patients of a natural cohort with breast cancer. Archives of Internal Medicine 2000;160:1109-15.

\section{Morrell 2010}

Morrell S, Barratt A, Irwig L, Howard K, Biesheuvel C, Armstrong B. Estimates of overdiagnosis of invasive breast cancer associated with screening mammography. Cancer Causes and Control 2010;21:275-82.

\section{Moss 2005}

Moss S, Thomas I, Evans A, Thomas B, Johns L. Randomised controlled trial of mammographic screening in women from age 40: results of screening in the first 10 years. British Journal of Cancer 2005;92:949-54.

\section{Moss 2006}

Moss SM, Cuckle H, Evans A, Johns L, Waller M, Bobrow L, for the Trial Management Group. Effect of mammographic screening from age 40 years on breast cancer mortality at 10 years' followup: a randomised controlled trial. The Lancet 2006;368:2053-60.

\section{Napoli 2009}

Napoli M. Reduce your risk of breast cancer: avoid mammograms. http://medicalconsumers.org/2009/07/14/cutyour-risk-of-breast-cancer-avoid-mammograms/ July 14, 2009. 


\section{Narod 1997}

Narod SA. On being the right size: A reappraisal of mammography trials in Canada and Sweden. The Lancet 1997;349:1849.

\section{Narod 2011}

Narod SA. Age of diagnosis, tumor size, and survival after breast cancer: implications for mammographic screening. Breast Cancer Research and Treatment 2011;128(1):259-66.

\section{Nattinger 2000}

Nattinger AB, Hoffmann RG, Kneusel RT, Schapira MM. Relation between appropriateness of primary therapy for early-stage breast carcinoma and increased use of breast-conserving surgery. The Lancet 2000;356(9236):1148-53.

\section{NBCC 2002}

National Breast Cancer Coalition. Positions, Facts and Analyses. http://www.stopbreastcancer.org/bin/index.htm (accessed 7 July 2002).

\section{Nelson 2009}

Nelson HD, Tyne K, Naik A, Bougatsos C, Chan BK, Humphrey L. Screening for breast cancer: an update for the U.S. Preventive Services Task Force. Annals of Internal Medicine 2009;151:727-37, W237-42.

\section{Newschaffer 2000}

Newschaffer CJ, Otani K, McDonald MK, Penberthy LT. Causes of death in elderly prostate cancer patients and in a comparison nonprostate cancer cohort. Journal of the National Cancer Institute 2000;92(8):613-21.

\section{NHS leaflet 2001}

Breast screening: an informed choice. www.cancerscreening.nhs.uk/breastscreen/publications/ ia-02.html (accessed 2 Oct, 2002).

\section{NHS leaflet 2010}

NHS Breast Screening Programme leaflet. Department of Health 2010:http://www.cancerscreening.nhs.uk/breastscreen/ publications/ia-02.html.

\section{Nielsen 1987}

Nielsen M, Thomsen JL, Primdahl S, Dyreborg U, Andersen JA. Breast cancer and atypia among young and middle-aged women: a study of 110 medicolegal autopsies. British Journal of Cancer 1987;56(6):814-9.

\section{Nixon 2000}

Nixon R, Prevost TC, Duffy SW, Tabar L, Vitak B, Chen HH. Some random-effects models for the analysis of matched-cluster randomised trials: application to the Swedish two-county trial of breast-cancer screening. Journal of Epidemiology and Biostatistics 2000;5(6):349-58.

\section{Njor 2007}

Njor SH, Olsen AH, Schwartz W, Vejborg I, Lynge E. Predicting the risk of a false-positive test for women following a mammography screening programme. Journal of Medical Screening 2007;14:94-7.

\section{Nyström 1993}

Nyström L, Rutqvist LE, Wall S, Lindgren A, Lindqvist M, Ryden S, et al. Breast cancer screening with mammography: overview of Swedish randomised trials. The Lancet 1993;341(8851):973-8.

\section{Nyström 1993a}

Nyström L, Larsson L-G. Breast cancer screening with mammography [reply]. The Lancet 1993;341:1531-2.

\section{Nyström 1996}

Nyström L, Larsson LG, Wall S, Rutqvist LE, Andersson I, Bjurstam N, et al. An overview of the Swedish randomised mammography trials: total mortality pattern and the representivity of the study cohorts. Journal of Medical Screening 1996;3(2):85-7.

\section{Nyström 1997}

Nyström L, Wall S, Rutqvist LE, Andersson I, Bjurstam N, Fagerberg G, et al. Update of the overview of the Swedish randomized trials on breast cancer screening with mammography. NIH Consensus Development Conference on Breast Cancer Screening for Women Ages 40-49. National Institutes of Health. 1997:65-9.

\section{Nyström 2000}

Nyström L. Assessment of population screening: the case of mammography [thesis]. Umeå: Umeå University Medical Dissertations, 2000.

\section{Nyström 2002}

Nyström L, Andersson I, Bjurstam N, Frisell J, Nordenskjöld B, Rutqvist LE. Long-term effects of mammography screening: updated overview of the Swedish randomised trials. The Lancet 2002;359(9310):909-19.

\section{Nyström 2002a}

Nyström L. Personal communication 31 July 2002.

\section{Nyström 2002b}

Nyström L, Andersson I, Bjurstam N, Frisell J, Rutqvist LE. Update on effects of screening mammography. The Lancet 2002;360:339-40.

\section{Olsen 2001a}

Olsen O, Gøtzsche PC. Cochrane review on screening for breast cancer with mammography. The Lancet 2001;358:1340-2.

\section{Olsen 2001b}

Olsen O, Gøtzsche PC. Systematic review of screening for breast cancer with mammography. http://image.thelancet.com/extras/ fullreport.pdf 2001.

\section{Olsen 2003}

Olsen AH, Jensen A, Njor SH, Villadsen E, Schwartz W, Vejborg I, et al. Breast cancer incidence after the start of mammography screening in Denmark. British Journal of Cancer 2003;88:362-5.

\section{Paci 2002}

Paci E, Duffy SW, Giorgi D, Zappa M, Crocetti E, Vezzosi V, et al. Are breast cancer screening programmes increasing rates of mastectomy? Observational study. BMJ 2002;325:418. 


\section{Patnick 2012}

Patnick J. NHS Breast Screening Programme: annual review 2011. NHS Breast Screening Programme 2012.

\section{Projektgruppen 1985}

Projektgruppen för WE-studien i Kopparbergs och Östergötlands län samt socialstyrelsens bearbetningsgrupp för WE-projektet. Reply on mammography [Replik om mammografi]. Läkartidningen 1985;82:2674.

\section{Prorok 2000}

Prorok PC. Personal communication 2 Febr 2000.

\section{Puffer 2003}

Puffer S, Torgerson D, Watson J. Evidence for risk of bias in cluster randomised trials: review of recent trials published in three general medical journals. BMJ 2003;327:785-9.

\section{Rapport 1982}

Rapport över mammografiscreening i Kopparbergs och Östergötlands läns landsting (WE-projektet) - Resultat efter första screeningsomgången. Unknown. Stockholm: Socialstyrelsen, 1982.

\section{Ries 2002}

Ries LAG, Eisner MP, Kosary CL, Hankey BF, Miller BA, Clegg L, et al. SEER Cancer Statistics Review, 1973-1999. http:// seer.cancer.gov/csr/1973_1999/. Bethesda, Md: National Cancer Institute, 2002 (accessed 26 June, 2003).

\section{Roberts 1984}

Roberts MM, Alexander FE, Anderson TJ, Forrest AP, Hepburn W, Huggins $A$, et al. The Edinburgh randomised trial of screening for breast cancer: description of method. British Journal of Cancer 1984;50(1):1-6.

\section{Roberts 1990}

Roberts MM, Alexander FE, Anderson TJ, Chetty U, Donnan PT, Forrest $\mathrm{P}$, et al. Edinburgh trial of screening for breast cancer: mortality at seven years. The Lancet 1990;335(8684):241-6.

\section{Rostgaard 2010}

Rostgaard K, Vaeth M, Rootzén H, Lynge E. Why did the breast cancer lymph node status distribution improve in Denmark in the pre-mammography screening period of 1978-1994?. Acta Oncologica 2010;49:313-321.

\section{Salz 2010}

Salz T, Richman AR, Brewer NT. Meta-analyses of the effect of false-positive mammograms on generic and specific psychosocial outcomes. Psychooncology 2010;19:1026-34.

\section{Schwartz 2000}

Schwartz LM, Woloshin S, Sox HC, Fischhoff B, Welch HG. US women's attitudes to false positive mammography results and detection of ductal carcinoma in situ: cross sectional survey. BMJ 2000;320:1635-40.

\section{Shapiro 1966}

Shapiro S, Strax P, Venet L. Evaluation of periodic breast cancer screening with mammography. Methodology and early observations. JAMA 1966;195(9):731-8.

\section{Shapiro 1972}

Shapiro S, Strax P, Venet L, Venet W. Changes in 5-year breast cancer mortality in a breast cancer screening program. Journal of the National Cancer Institute 1972;7:663-78.

\section{Shapiro 1977}

Shapiro S. Evidence on screening for breast cancer from a randomized trial. Cancer 1977;39 Suppl(6):2772-82.

\section{Shapiro 1982}

Shapiro S, Venet W, Strax P, Venet L, Roeser R. Ten- to fourteenyear effect of screening on breast cancer mortality. Journal of the National Cancer Institute 1982;69(2):349-55.

\section{Shapiro 1985}

Shapiro S, Venet W, Strax P, Venet L, Roeser R. Selection, follow-up, and analysis in the Health Insurance Plan Study: a randomized trial with breast cancer screening. Journal of the National Cancer Institute. Monographs 1985;67:65-74.

\section{Shapiro 1985a}

Shapiro S. Discussion II. Journal of the National Cancer Institute. Monographs 1985;67:75.

\section{Shapiro 1988}

Shapiro S, Venet W, Strax P, Venet L. Periodic screening for breast cancer: The health insurance plan project and its sequelae, 1963-1986. Baltimore: Johns Hopkins University Press, 1988:The health insurance plan project and its sequelae.

\section{Shapiro 1989}

Shapiro S. The status of breast cancer screening: a quarter of a century of research. World Journal of Surgery 1989;13(1):9-18.

\section{Shapiro 1994}

Shapiro S. Screening: assessment of current studies. Cancer 1994;74 Suppl(1):231-8.

\section{Skrabanek 1993}

Skrabanek P. Breast cancer screening with mammography [letter]. The Lancet 1993;341:1531.

\section{Slaytor 1998}

Slaytor EK, Ward JE. How risks of breast cancer and benefits of screening are communicated to women: analysis of 58 pamphlets. BMJ 1998;317(7153):263-4.

\section{Smart 1995}

Smart CR, Hendrick RE, Rutledge JH 3rd, Smith RA. Benefit of mammography screening in women ages 40 to 49 years. Current evidence from randomized controlled trials. Cancer 1995;75(7):1619-26.

\section{Smith-Bindman 2003}

Smith-Bindman R, Chu PW, Miglioretti DL, Sickles EA, Blanks R, Ballard-Barbash R, et al. Comparison of screening 
mammography in the United States and the United kingdom. JAMA 2003;290:2129-37.

\section{Socialstyrelsen 1985}

Socialstyrelsens beredningsgrupp för WE-projektet. Minskad mortalitet i bröstcancer genom hälskontroll med mammografi. Nordisk Medicin 1985;100:175-8.

\section{Statusrapport 1997}

Unknown. Tidlig opsporing og behandling af brystkræft: statusrapport. København: Sundhedsstyrelsen, 1997.

\section{Strax 1973}

Strax P, Venet L, Shapiro S. Value of mammography in reduction of mortality from breast cancer in mass screening. The American Journal of Roentgenology, Radium Therapy, and Nuclear Medicine 1973;117(3):686-9.

\section{Suhrke 2011}

Suhrke P, Mæhlen J, Schlichting E, Jørgensen KJ, Gøtzsche PC, Zahl P-H. Effect of mammography screening on surgical treatment for breast cancer in Norway: comparative analysis of cancer registry data. BMJ 2011;343:d4692.

\section{Swed Cancer Soc 1996}

Swedish Cancer Society and the Swedish National Board of Health and Welfare. Breast-cancer screening with mammography in women aged 40-49 years. International Journal of Cancer 1996;68(6):693-9.

\section{Swift 1993}

Swift M. Screening mammography [letter]. The Lancet 1993;342:549-50.

\section{Tabar 1979}

Tabar L, Gad A, Akerlund E, Fors B, Fagerberg G, Baldetorp L. Screening for breast cancer in Sweden. A randomised controlled trial. In: Logan WW, Muntz EP editor(s). Reduced dose mammography. New York: Masson, 1979:407-14.

\section{Tabar 1981}

Tabar L, Gad A. Screening for breast cancer: the Swedish trial. Radiology 1981;138(1):219-22.

\section{Tabar 1985}

Tabar L, Fagerberg CJ, Gad A, Baldetorp L, Holmberg LH, Grontoft O, et al. Reduction in mortality from breast cancer after mass screening with mammography. Randomised trial from the Breast Cancer Screening Working Group of the Swedish National Board of Health and Welfare. Lancet 1985;1(8433):829-32.

\section{Tabar 1985a}

Tabar L, Gad A, Holmberg L, Ljungquist U. Significant reduction in advanced breast cancer. Results of the first seven years of mammography screening in Kopparberg, Sweden. Diagnostic Imaging in Clinical Medicine 1985;54(3-4):158-64.

\section{Tabar 1988}

Tabar L, Fagerberg CJG, Day NE. The results of periodic oneview mammographic screening in Sweden. Part 2: Evaluation of the results. In: Day NE, Miller AB editor(s). Screening for breast cancer. Toronto: Hans Huber, 1988:39-44.

\section{Tabar 1989}

Tabar L, Fagerberg G, Duffy SW, Day NE. The Swedish two county trial of mammographic screening for breast cancer: recent results and calculation of benefit. Journal of Epidemiology and Community Health 1989;43(2):107-14.

\section{Tabar 1990}

Tabar L, Duffy SW, Day NE. Screening with mammography [letter]. International Journal of Technology Assessment in Health Care 1990;6(3):498-500.

\section{Tabar 1991}

Tabar L, Fagerberg CJG, South MC, Day NE, Duffy SW. The Swedish Two-county Trial of mammographic screening for breast cancer: recent results on mortality and tumour characteristics. In: Miller AB, Chamberlain J, Day NE, et al. editor(s). Cancer screening. Cambridge: Cambridge University Press, 1991:23-36.

\section{Tabar 1992}

Tabar L, Fagerberg G, Duffy SW, Day NE, Gad A, Grontoft O. Update of the Swedish two-county program of mammographic screening for breast cancer. Radiologic Clinics of North America 1992;30(1):187-210.

\section{Tabar 1995}

Tabar L, Fagerberg G, Chen HH, Duffy SW, Smart CR, Gad A, et al. Efficacy of breast cancer screening by age. New results from the Swedish Two-County Trial. Cancer 1995;75(10):2507-17.

\section{Tabar 1996}

Tabar L, Fagerberg G, Chen HH, Duffy SW, Gad A. Tumour development, histology and grade of breast cancers: prognosis and progression. International Journal of Cancer 1996;66:413-9.

\section{Tabar 1999}

Tabar L, Chen HH, Duffy SW, Krusemo UB. Primary and adjuvant therapy, prognostic factors and survival in 1053 breast cancers diagnosed in a trial of mammography screening. Japanese Journal of Clinical Oncology 1999;29(12):608-16.

\section{Tabar 2000}

Tabar L, Vitak B, Chen HH, et al. The Swedish Two-County Trial twenty years later. Updated mortality results and new insights from long-term follow-up. Radiologic Clinics of North America 2000;38(4):625-51.

\section{Tabar 2000a}

Tabar L. Personal communication 17 Jan 2000.

\section{Tabar 2001}

Tabar L, Vitak B, Chen HH, Yen MF, Duffy SW, Smith RA. Beyond randomized controlled trials: organized mammographic screening substantially reduces breast carcinoma mortality. Cancer 2001;91(9):1724-31. 


\section{Tabar 2002}

Tabár L, Smith RA, Duffy SW. Update on effects of screening mammography. Lancet 2002;360:337.

\section{Tabar 2002a}

Tabar L, Duffy SW, Yen MF, Warwick J, Vitak B, Chen HH, et al. All-cause mortality among breast cancer patients in a screening trial: support for breast cancer mortality as an end point. Journal of Medical Screening 2002;9(4):159-62.

\section{Tabar 2003}

Tabar L, Smith RA, Vitak B, Yen MF, Chen TH, Warwick J, et al. Mammographic screening: a key factor in the control of breast cancer. Cancer Journal 2003;9(1):15-27.

\section{Tabar 2003a}

Tabar L, Yen MF, Vitak B, Chen HH, Smith RA, Duffy SW. Mammography service screening and mortality in breast cancer patients: 20-year follow-up before and after introduction of screening. Lancet 2003;361:1405-10.

\section{The Lancet Erratum 2002}

The Lancet Erratum. Department of error: update on screening mammography. The Lancet 2002; Vol. 360, issue 9340:1178.

\section{Thomas 1977}

Thomas LB, Ackerman LV, McDivitt RW, Hanson TAS, Hankey BF, Prorok PC. Report of $\mathrm{NCl}$ ad hoc pathology working group to review the gross and microscopic findings of breast cancer cases in the HIP study. Journal of the National Cancer Institute 1977;59(2):496-541.

\section{Thornton 1997}

Thornton $\mathrm{H}$. The voice of the breast cancer patient - a lonely cry in the wilderness. European Journal of Cancer 1997;33(6):825-8.

\section{UK review 2012}

Independent UK Panel on Breast Cancer Screening. The benefits and harms of breast cancer screening: an independent review. Lancet 2010;380:1778-86.

\section{US Task Force 2002}

US Preventive Services Task Force. Screening for breast cancer: recommendations and rationale. Annals of Internal Medicine 2002;137(5 Part 1):344-6.

\section{Wald 1993}

Wald NJ, Chamberlain J, Hackshaw A. Report of the European Society for Mastology Breast Cancer Screening Evaluation Committee (1993). Breast 1993;2:209-16.

\section{Walter 1999}

Walter SD, Jadad AR. Meta-analysis of screening data: a survey of the literature. Statistics in Medicine 1999;18(24):3409-24.

\section{Welch 1997}

Welch HG, Black WC. Using autopsy series to estimate the disease reservoir for ductal carcinoma in situ of the breast. Annals of Internal Medicine 1997;127:1023-8.

\section{Welch 2006}

Welch HG. How much overdiagnosis?. BMJ 2006 Mar 10:http:// www.bmj.com/content/332/7543/689?tab=responses (accessed $21 \mathrm{Dec} 2012$ )

\section{Werkö 1995}

Werkö L. Mammografi, vinst och risk. Läkartidningen 1995;92:4540.

\section{Westerholm 1988}

Westerholm B. Stötande syn på medelålders kvinnors värde. Läkartidningen 1988;85(47):4056-7.

\section{Zahl 2001}

Zahl P-H, Kopjar B, Mæhlen J. Norwegian breast cancer mortality rates and validity in Swedish mammography trials. Tidsskrift for den Norske Lægeforening 2001;121:1928-31.

\section{Zahl 2004}

Zahl PH, Strand BH, Maehlen J. Incidence of breast cancer in Norway and Sweden during introduction of nationwide screening: prospective cohort study. BMJ 2004;328:921-4.

\section{Zahl 2006}

Zahl P-H, Gøtzsche PC, Andersen JM, Mæhlen J. Results of the Two-County trial of mammography screening are not compatible with contemporaneous official Swedish breast cancer statistics. Danish Medical Bulletin 2006;53:438-40.

\section{Zahl 2008}

Zahl PH, Mæhlen J, Welch HG. The natural history of breast cancers detected by screening mammography. Archives of Internal Medicine 2008;168:2311-6.

\section{Zahl 2011}

Zahl PH, Gøtzsche PC, Mæhlen J. Natural history of breast cancers detected in the Swedish mammography screening programme: a cohort study. Lancet Oncology 2011;12(12):1118-24.

\section{References to other published versions of this review}

Gøtzsche 2006

Gøtzsche PC, Nielsen M. Screening for breast cancer with mammography. Cochrane Database of Systematic Reviews 2006, Issue 4. [DOI: 10.1002/14651858.CD001877]

\section{Gøtzsche 2009a}

Gøtzsche PC, Nielsen M. Screening for breast cancer with mammography. Cochrane Database of Systematic Reviews 2009, Issue 4. [DOI: 10.1002/14651858.CD001877]

\section{Olsen 2001}

Olsen O, Gøtzsche PC. Screening for breast cancer with mammography. Cochrane Database of Systematic Reviews 2001, Issue 4. [DOI: 10.1002/14651858.CD001877]

* Indicates the major publication for the study 
CHARACTERISTICS OF STUDIES

Characteristics of included studies [ordered by study ID]

Canada 1980

Methods Individual randomisation in blocks of 2 or 4, stratified by centre and 5-year age group (see also text).

Cause of death was assessed blinded and independently by two specialists for women with diagnosed breast cancer and for other possible breast cancer deaths.

Participants $\quad$ Women aged 40-59 years.
Number randomised: see below.

Interventions Two-view mammography: cranio-caudal and mediolateral (later medio-lateral oblique except in two centres).

4-5 cycles of screening with yearly interval.

\begin{tabular}{|c|c|c|}
\hline Outcomes & \multicolumn{2}{|l|}{$\begin{array}{l}\text { Total mortality. } \\
\text { Breast cancer mortality. } \\
\text { Surgical interventions. }\end{array}$} \\
\hline Notes & \multicolumn{2}{|c|}{ Attendance rate: $100 \%$ in first round. } \\
\hline \multicolumn{3}{|l|}{ Risk of bias } \\
\hline Bias & Authors' judgement & Support for judgement \\
\hline $\begin{array}{l}\text { Random sequence genera- } \\
\text { tion (selection bias) }\end{array}$ & Low risk & $\begin{array}{l}\text { Computer-generated block randomization with two block sizes (equalled out } \\
\text { the allocations only after every } 48 \text { entries; Baines, personal information, June } \\
\text { 2011). }\end{array}$ \\
\hline $\begin{array}{l}\text { Allocation concealment } \\
\text { (selection bias) }\end{array}$ & Low risk & Adequate, see text. \\
\hline $\begin{array}{l}\text { Blinding of participants } \\
\text { and personnel (perfor- } \\
\text { mance bias) } \\
\text { All outcomes }\end{array}$ & Low risk & Not possible for a screening trial and not relevant. \\
\hline $\begin{array}{l}\text { Blinding of outcome as- } \\
\text { sessment (detection bias) } \\
\text { All outcomes }\end{array}$ & Low risk & Cause of death was assessed blinded. \\
\hline $\begin{array}{l}\text { Incomplete outcome data } \\
\text { (attrition bias) } \\
\text { All outcomes }\end{array}$ & Low risk & $\begin{array}{l}\text { Very few women excluded after randomisation (see text) and none because of } \\
\text { previous breast cancer. }\end{array}$ \\
\hline $\begin{array}{l}\text { Selective reporting (re- } \\
\text { porting bias) }\end{array}$ & Low risk & This trial has been meticulously reported and documented. \\
\hline Other bias & Low risk & \\
\hline
\end{tabular}


Canada 1980a

\begin{tabular}{ll}
\hline Methods & See Canada 1980. \\
\hline Participants & Women aged 40-49 years. \\
50,472 randomised. & 59 were excluded from analyses, distributed equally between the two groups. \\
\hline Interventions & See Canada 1980. \\
& $\begin{array}{l}\text { Screened women had an annual clinical examination while control women were examined at the first } \\
\text { visit and were taught self-examination at that visit and were reminded annually by mail. }\end{array}$ \\
\hline Outcomes & See Canada 1980. \\
\hline Notes & Attendance rate: $100 \%$ in first round, $89 \%$ in second, decreasing to $86 \%$ in fifth round. \\
& Mammography in control group: $26 \%$, most only once during the trial. \\
\hline
\end{tabular}

\section{Risk of bias}

\begin{tabular}{|c|c|c|}
\hline Bias & Authors' judgement & Support for judgement \\
\hline $\begin{array}{l}\text { Random sequence genera- } \\
\text { tion (selection bias) }\end{array}$ & Low risk & See Canada 1980. \\
\hline $\begin{array}{l}\text { Allocation concealment } \\
\text { (selection bias) }\end{array}$ & Low risk & See Canada 1980. \\
\hline $\begin{array}{l}\text { Blinding of participants } \\
\text { and personnel (perfor- } \\
\text { mance bias) } \\
\text { All outcomes }\end{array}$ & Low risk & See Canada 1980. \\
\hline $\begin{array}{l}\text { Blinding of outcome as- } \\
\text { sessment (detection bias) } \\
\text { All outcomes }\end{array}$ & Low risk & See Canada 1980. \\
\hline $\begin{array}{l}\text { Incomplete outcome data } \\
\text { (attrition bias) } \\
\text { All outcomes }\end{array}$ & Low risk & See Canada 1980. \\
\hline $\begin{array}{l}\text { Selective reporting (re- } \\
\text { porting bias) }\end{array}$ & Low risk & See Canada 1980. \\
\hline Other bias & Low risk & See Canada 1980. \\
\hline
\end{tabular}

\section{Canada 1980b}

\begin{tabular}{ll}
\hline Methods & See Canada 1980. \\
\hline Participants & Women aged $50-59$ years. \\
& 39,459 randomised. \\
& 54 were excluded from analyses, distributed equally between the two groups. \\
\hline
\end{tabular}


Canada 1980b (Continued)
Interventions
See Canada 1980.
All women had their breasts examined annually.

\begin{tabular}{ll}
\hline Outcomes & See Canada 1980. \\
\hline Notes & Attendance rate: $100 \%$ in first round, $90 \%$ in second, decreasing to $87 \%$ in fifth round. \\
& Mammography in control group: $17 \%$.
\end{tabular}

\section{Risk of bias}

\begin{tabular}{|c|c|c|}
\hline Bias & Authors' judgement & Support for judgement \\
\hline $\begin{array}{l}\text { Random sequence genera- } \\
\text { tion (selection bias) }\end{array}$ & Low risk & See Canada 1980. \\
\hline $\begin{array}{l}\text { Allocation concealment } \\
\text { (selection bias) }\end{array}$ & Low risk & See Canada 1980. \\
\hline $\begin{array}{l}\text { Blinding of participants } \\
\text { and personnel (perfor- } \\
\text { mance bias) } \\
\text { All outcomes }\end{array}$ & Low risk & See Canada 1980. \\
\hline $\begin{array}{l}\text { Blinding of outcome as- } \\
\text { sessment (detection bias) } \\
\text { All outcomes }\end{array}$ & Low risk & See Canada 1980. \\
\hline $\begin{array}{l}\text { Incomplete outcome data } \\
\text { (attrition bias) } \\
\text { All outcomes }\end{array}$ & Low risk & See Canada 1980. \\
\hline $\begin{array}{l}\text { Selective reporting (re- } \\
\text { porting bias) }\end{array}$ & Low risk & See Canada 1980. \\
\hline Other bias & Low risk & See Canada 1980. \\
\hline
\end{tabular}

\section{Edinburgh 1978}

Methods Stratified cluster randomisation; general practices were clusters; stratification was by size of practice. About 87 clusters (numbers vary in different reports, see text).

Blinding of outcome assessment not stated.

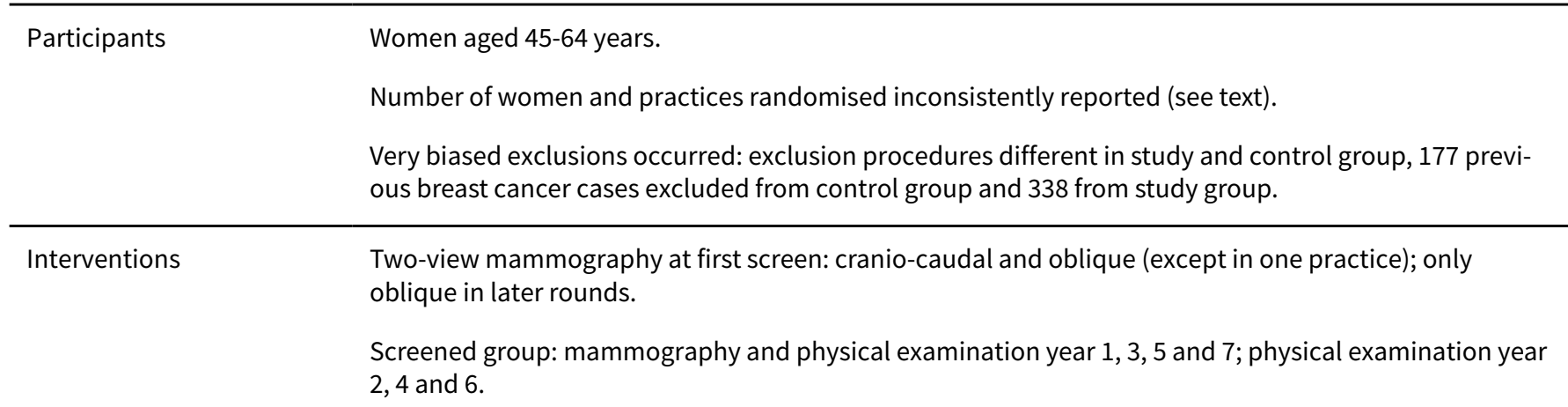


Edinburgh 1978 (Continued)

Control group: usual care.

\begin{tabular}{ll}
\hline Outcomes & $\begin{array}{l}\text { Total mortality. } \\
\text { Breast cancer mortality. } \\
\text { Radiotherapy. }\end{array}$ \\
\hline Notes & Attendance rate: Circa $60 \%$ in first round; $44 \%$ in seventh round. \\
& Mammography in control group: unknown.
\end{tabular}

\section{Risk of bias}

\begin{tabular}{lll}
\hline Bias & Authors' judgement & Support for judgement \\
\hline $\begin{array}{l}\text { Random sequence genera- } \\
\text { tion (selection bias) }\end{array}$ & High risk & No information, but some clusters later changed allocation status. \\
\hline $\begin{array}{l}\text { Allocation concealment } \\
\text { (selection bias) }\end{array}$ & High risk & $\begin{array}{l}\text { The randomisation failed to an important degree to create comparable } \\
\text { groups. }\end{array}$ \\
\hline $\begin{array}{l}\text { Blinding of participants } \\
\text { and personnel (perfor- } \\
\text { mance bias) } \\
\text { All outcomes }\end{array}$ & Low risk & Not possible for a screening trial and not relevant. \\
\hline $\begin{array}{l}\text { Blinding of outcome as- } \\
\text { sessment (detection bias) }\end{array}$ & High risk & Not stated. \\
$\begin{array}{l}\text { All outcomes } \\
\begin{array}{l}\text { Incomplete outcome data } \\
\text { (attrition bias) } \\
\text { All outcomes }\end{array}\end{array}$ & High risk & Not relevant, as randomisation failed to create comparable groups. \\
\hline $\begin{array}{l}\text { Selective reporting (re- } \\
\text { porting bias) }\end{array}$ & Unclear risk & Not relevant, as randomisation failed to create comparable groups. \\
\hline \begin{tabular}{l} 
Other bias \\
\hline
\end{tabular} & High risk & Not relevant, as randomisation failed to create comparable groups. \\
\hline
\end{tabular}

\section{Göteborg 1982}

\begin{tabular}{ll}
\hline Methods & See Göteborg 1982a and 1982b. \\
\hline Participants & Women aged 39-59 years. \\
& Number of women randomised: 21,904 to screening, 30,318 to control (see also text). \\
& $\begin{array}{l}254 \text { women (1.2\%) excluded from the screening group and } 357(1.2 \%) \text { from the control group due to a } \\
\text { history of breast carcinoma prior to randomisation. }\end{array}$ \\
\hline Interventions & See Göteborg 1982a and 1982b. \\
\hline Outcomes & Total mortality. \\
\hline Notes & Mammography in control group: $18 \%$ during last two years. \\
\hline
\end{tabular}


Göteborg 1982 (Continued)

Risk of bias

\begin{tabular}{|c|c|c|}
\hline Bias & Authors' judgement & Support for judgement \\
\hline $\begin{array}{l}\text { Random sequence genera- } \\
\text { tion (selection bias) }\end{array}$ & High risk & $\begin{array}{l}\text { Day of birth used. Randomisation ratios varied, not clear whether this was tak- } \\
\text { en into account in the analysis. }\end{array}$ \\
\hline $\begin{array}{l}\text { Allocation concealment } \\
\text { (selection bias) }\end{array}$ & High risk & Day of birth. \\
\hline $\begin{array}{l}\text { Blinding of participants } \\
\text { and personnel (perfor- } \\
\text { mance bias) } \\
\text { All outcomes }\end{array}$ & Low risk & Not possible for a screening trial and not relevant. \\
\hline $\begin{array}{l}\text { Blinding of outcome as- } \\
\text { sessment (detection bias) } \\
\text { All outcomes }\end{array}$ & Low risk & Blinding of outcome assessment. \\
\hline $\begin{array}{l}\text { Incomplete outcome data } \\
\text { (attrition bias) } \\
\text { All outcomes }\end{array}$ & Low risk & Women with previous breast cancer were excluded after randomisation. \\
\hline $\begin{array}{l}\text { Selective reporting (re- } \\
\text { porting bias) }\end{array}$ & Low risk & We found no evidence for this. \\
\hline Other bias & High risk & $\begin{array}{l}\text { The whole control group was invited to screening when the trial ended, which } \\
\text { renders follow-up data unreliable. }\end{array}$ \\
\hline
\end{tabular}

Göteborg 1982a

\begin{tabular}{|c|c|}
\hline Methods & $\begin{array}{l}\text { Individual randomisation within year of birth cohort - by day of birth in the cohorts } 1923-1935 \text { and by } \\
\text { computer software for the cohorts 1936-1944 - randomisation ratio varied by cohort, on average ap- } \\
\text { proximately 1:1.2 (see also text). } \\
\text { Blinding of outcome assessment. }\end{array}$ \\
\hline Participants & $\begin{array}{l}\text { Women aged } 39-49 \text { years. } \\
\text { Number of women randomised: } 11,792 \text { to screening, } 14,321 \text { to control (see also text). } \\
68 \text { women }(0.6 \%) \text { excluded from the screening group and } 104(0.7 \%) \text { from the control group due to a } \\
\text { history of breast carcinoma prior to randomisation. }\end{array}$ \\
\hline Interventions & $\begin{array}{l}\text { Two-view mammography at first screen, single at later rounds - single read at first three rounds; double } \\
\text { read thereafter. } \\
5 \text { cycles with an interval of } 18 \text { months. } \\
\text { Control group: usual care. }\end{array}$ \\
\hline Outcomes & $\begin{array}{l}\text { Total mortality. } \\
\text { Breast cancer mortality. }\end{array}$ \\
\hline Notes & $\begin{array}{l}\text { Attendance rate: } 85 \%, 78 \%, 79 \%, 77 \%, 75 \% \text { in rounds } 1-5 \text {. } \\
66 \% \text { at first screen in control group. } \\
\text { Mammography in control group: } 19 \% \text { during last two years; } 51 \% \text { ever. }\end{array}$ \\
\hline
\end{tabular}


Göteborg 1982a (Continued)

Early systematic screening of control group.

\section{Risk of bias}

\begin{tabular}{lll}
\hline Bias & Authors' judgement & Support for judgement \\
\hline $\begin{array}{l}\text { Random sequence genera- } \\
\text { tion (selection bias) }\end{array}$ & Unclear risk & See Göteborg 1982. \\
\hline $\begin{array}{l}\text { Allocation concealment } \\
\text { (selection bias) }\end{array}$ & Unclear risk & See Göteborg 1982. \\
\hline $\begin{array}{l}\text { Blinding of participants } \\
\text { and personnel (perfor- } \\
\text { mance bias) } \\
\text { All outcomes }\end{array}$ & Low risk & See Göteborg 1982. \\
\hline $\begin{array}{l}\text { Blinding of outcome as- } \\
\text { sessment (detection bias) } \\
\text { All outcomes }\end{array}$ & Low risk & See Göteborg 1982. \\
\hline $\begin{array}{l}\text { Incomplete outcome data } \\
\text { (attrition bias) } \\
\text { All outcomes }\end{array}$ & Low risk & See Göteborg 1982. \\
\hline $\begin{array}{l}\text { Selective reporting (re- } \\
\text { porting bias) }\end{array}$ & Low risk & \\
\hline \begin{tabular}{l} 
Other bias \\
\hline
\end{tabular} & High risk & See Göteborg 1982. \\
\hline
\end{tabular}

Göteborg 1982b

Methods Individual randomisation by computer software - randomisation ratio varied by cohort, on average ap proximately 1:1.6.

Blinding of outcome assessment.

Women aged 50-59 years.
$\begin{aligned} & \text { Number of women randomised not stated explicitly, but can be calculated by comparing two trial re- } \\ & \text { ports (see Göteborg } 1992 \text { above for total numbers). }\end{aligned}$

Interventions Two-view mammography at first screen, single at later rounds - single read at first three rounds; double read thereafter.

4 cycles with an interval of 18 months.

Control group: usual care.

\begin{tabular}{ll}
\hline Outcomes & $\begin{array}{l}\text { Total mortality. } \\
\text { Breast cancer mortality. }\end{array}$ \\
\hline Notes & $\begin{array}{l}\text { Attendance rate: } 83 \% \text { at first screen. } \\
78 \% \text { at first screen in control group. } \\
\text { Early systematic screening of control group. }\end{array}$
\end{tabular}

\section{Risk of bias}

Screening for breast cancer with mammography (Review) 
Göteborg 1982b (Continued)

\begin{tabular}{|c|c|c|}
\hline Bias & Authors' judgement & Support for judgem \\
\hline $\begin{array}{l}\text { Random sequence genera- } \\
\text { tion (selection bias) }\end{array}$ & Unclear risk & See Göteborg 1982. \\
\hline $\begin{array}{l}\text { Allocation concealment } \\
\text { (selection bias) }\end{array}$ & Unclear risk & See Göteborg 1982. \\
\hline $\begin{array}{l}\text { Blinding of participants } \\
\text { and personnel (perfor- } \\
\text { mance bias) } \\
\text { All outcomes }\end{array}$ & Low risk & See Göteborg 1982. \\
\hline $\begin{array}{l}\text { Blinding of outcome as- } \\
\text { sessment (detection bias) } \\
\text { All outcomes }\end{array}$ & Low risk & See Göteborg 1982. \\
\hline $\begin{array}{l}\text { Incomplete outcome data } \\
\text { (attrition bias) } \\
\text { All outcomes }\end{array}$ & Low risk & See Göteborg 1982. \\
\hline
\end{tabular}

Selective reporting (re- $\quad$ Low risk $\quad$ See Göteborg 1982.
porting bias)

\begin{tabular}{lll}
\hline Other bias $\quad$ High risk $\quad$ See Göteborg 1982. \\
\hline
\end{tabular}

Kopparberg 1977

Methods Stratified cluster randomisation; seven blocks each contained 3 units (in three blocks the units were parishes and in four municipalities); randomisation ratio 2:1 (see also text).

Blinding of outcome assessment not stated.

\begin{tabular}{ll}
\hline Participants & Women aged 40 years and above. \\
& 21 units randomised: 47,389 women in screening areas and 22,658 in control areas (33,641 vs. 16,359 in \\
age group 40-69 years; 39,051 versus 18,846 in age group 40-74 years). & No parishes or municipalities excluded. Exclusion criteria for patients unclear but probably biased (see \\
text).
\end{tabular}


Kopparberg 1977 (Continued)

Mammography in control group: $13 \%$.

\section{Risk of bias}

Bias Authors' judgement Support for judgement

Random sequence genera- Unclear risk See Two-County 1977.

tion (selection bias)

\begin{tabular}{lll}
\hline $\begin{array}{l}\text { Allocation concealment } \\
\text { (selection bias) }\end{array}$ & High risk & See Two-County 1977.
\end{tabular}

\begin{tabular}{l}
\hline Blinding of participants $\quad$ Low risk $\quad$ See Two-County 1977. \\
and personnel (perfor- \\
mance bias) \\
All outcomes
\end{tabular}

\begin{tabular}{|c|c|c|}
\hline $\begin{array}{l}\text { Blinding of outcome as- } \\
\text { sessment (detection bias) } \\
\text { All outcomes }\end{array}$ & High risk & See Two-County 1977. \\
\hline $\begin{array}{l}\text { Incomplete outcome data } \\
\text { (attrition bias) } \\
\text { All outcomes }\end{array}$ & High risk & See Two-County 1977. \\
\hline $\begin{array}{l}\text { Selective reporting (re- } \\
\text { porting bias) }\end{array}$ & High risk & See Two-County 1977. \\
\hline Other bias & High risk & See Two-County 1977. \\
\hline
\end{tabular}

Malmö 1976

\begin{tabular}{|c|c|}
\hline \multirow[t]{2}{*}{ Methods } & $\begin{array}{l}\text { Individual randomisation; within each birth cohort a computer list was randomised and the first half in- } \\
\text { vited for screening. }\end{array}$ \\
\hline & $\begin{array}{l}\text { Blinding of outcome assessment: deaths among breast cancer cases assessed blinded and indepen- } \\
\text { dently by a pathologist and an oncologist; discrepancies resolved by an internist. }\end{array}$ \\
\hline \multirow[t]{3}{*}{ Participants } & Women aged $45-69$ years. \\
\hline & 21,242 randomised into screened group; 21,240 or 21,244 into control group (see text). \\
\hline & $\begin{array}{l}\text { Biased exclusions seem to have occurred: } 154 \text { women excluded from control group, } 49 \text { from study } \\
\text { group (see text). }\end{array}$ \\
\hline \multirow[t]{4}{*}{ Interventions } & $\begin{array}{l}\text { One-view or two-view mammography; two-view in 1st and } 2 \text { nd round; one-view or two-view in later } \\
\text { rounds depending on parenchymal pattern. }\end{array}$ \\
\hline & 5-6 cycles according to protocol; 8 cycles in 1988; more during $1988-1992$. \\
\hline & Interval between screens: $18-24$ months. \\
\hline & Control group: usual care. \\
\hline Outcomes & $\begin{array}{l}\text { Total mortality. } \\
\text { Breast cancer mortality. } \\
\text { Surgical interventions. } \\
\text { Chemotherapy. }\end{array}$ \\
\hline
\end{tabular}


Malmö 1976 (Continued)

Radiotherapy.

Notes $\quad$ Attendance rate: Circa $70 \% ; 74 \%$ in first round ranging from $64 \%$ in oldest age group to $79 \%$ in youngest.

Mammography in control group: screening offered to age group 50-69 years in 1991; invited in 1992 and completed in 1993.

$6 \%$ had more than 3 mammograms during study; $24 \%$ had one or more; $35 \%$ among women aged $45-49$ years at entry.

\section{Risk of bias}

\begin{tabular}{|c|c|c|}
\hline Bias & Authors' judgement & Support for judgement \\
\hline $\begin{array}{l}\text { Random sequence genera- } \\
\text { tion (selection bias) }\end{array}$ & Low risk & Computer. \\
\hline $\begin{array}{l}\text { Allocation concealment } \\
\text { (selection bias) }\end{array}$ & Low risk & Done by a computer on one occasion for the whole sample. \\
\hline $\begin{array}{l}\text { Blinding of participants } \\
\text { and personnel (perfor- } \\
\text { mance bias) } \\
\text { All outcomes }\end{array}$ & Low risk & Not possible for a screening trial and not relevant. \\
\hline $\begin{array}{l}\text { Blinding of outcome as- } \\
\text { sessment (detection bias) } \\
\text { All outcomes }\end{array}$ & Low risk & Blinding of outcome assessment. \\
\hline $\begin{array}{l}\text { Incomplete outcome data } \\
\text { (attrition bias) } \\
\text { All outcomes }\end{array}$ & Low risk & Very few women missing. \\
\hline $\begin{array}{l}\text { Selective reporting (re- } \\
\text { porting bias) }\end{array}$ & Low risk & This trial has been meticulously reported and documented. \\
\hline Other bias & Low risk & \\
\hline
\end{tabular}

\section{Malmö II 1978}

Methods See text of the review; extension of Malmö 1976.

\section{Participants}

Interventions

\section{Outcomes}

Notes

\section{Risk of bias}


Malmö II 1978 (Continued)

Random sequence genera- High risk See text of the review; extension of Malmö 1976, not done according to a fortion (selection bias) mal protocol, inclusion criteria violated, group sizes differed although they should have been the same, and gross and unexplained imbalance in numbers in the two groups.

\begin{tabular}{lll}
\hline $\begin{array}{l}\text { Allocation concealment } \\
\text { (selection bias) }\end{array}$ & High risk & See 'Random sequence generation.' \\
\hline $\begin{array}{l}\text { Blinding of participants } \\
\text { and personnel (perfor- } \\
\text { mance bias) }\end{array}$ & Low risk & Not possible for a screening trial and not relevant. \\
All outcomes &
\end{tabular}

\begin{tabular}{|c|c|c|}
\hline $\begin{array}{l}\text { Blinding of outcome as- } \\
\text { sessment (detection bias) } \\
\text { All outcomes }\end{array}$ & High risk & See 'Random sequence generation.' \\
\hline $\begin{array}{l}\text { Incomplete outcome data } \\
\text { (attrition bias) } \\
\text { All outcomes }\end{array}$ & High risk & See 'Random sequence generation.' \\
\hline $\begin{array}{l}\text { Selective reporting (re- } \\
\text { porting bias) }\end{array}$ & High risk & See 'Random sequence generation.' \\
\hline Other bias & High risk & See 'Random sequence generation.' \\
\hline
\end{tabular}

\section{New York 1963}

Methods Individual randomisation within matched pairs; pairs derived from a computer list sorted by age, family size and employment group.

A blinded review was carried out in a subsample of death certificates where cause of death was breast cancer. The panel much more often stated breast cancer as cause of death in the control group.

\begin{tabular}{|c|c|}
\hline Participants & $\begin{array}{l}\text { Women aged } 40-64 \text { years. } \\
\text { Probably 31,092 pairs of women were randomised into screening and control group. } \\
\text { Very biased exclusions occurred: probably } 336 \text { previous breast cancer cases were excluded from the } \\
\text { control group and } 853 \text { from study group (see text). }\end{array}$ \\
\hline Interventions & $\begin{array}{l}\text { Two view mammography: cephalocaudal and lateral. } \\
4 \text { cycles (three were planned according to the first publications). } \\
\text { Screened group: annual physical examinations. } \\
\text { Control group: usual care. }\end{array}$ \\
\hline Outcomes & $\begin{array}{l}\text { Total mortality. } \\
\text { Breast cancer mortality. } \\
\text { Surgical interventions. } \\
\text { Radiotherapy. }\end{array}$ \\
\hline Notes & $\begin{array}{l}\text { Attendance rate: } 65 \% \text { in total population, circa } 58 \%, 50 \% \text { and } 40 \% \text { participated in } 2,3 \text { and } 4 \text { screens, re- } \\
\text { spectively. } \\
\text { Mammography in control group: not described. }\end{array}$ \\
\hline
\end{tabular}


New York 1963 (Continued)

Risk of bias

\begin{tabular}{|c|c|c|}
\hline Bias & Authors' judgement & Support for judgement \\
\hline $\begin{array}{l}\text { Random sequence genera- } \\
\text { tion (selection bias) }\end{array}$ & High risk & $\begin{array}{l}\text { Confusing information and the exact number of randomised women not stat- } \\
\text { ed. }\end{array}$ \\
\hline $\begin{array}{l}\text { Allocation concealment } \\
\text { (selection bias) }\end{array}$ & Unclear risk & Unclear. \\
\hline $\begin{array}{l}\text { Blinding of participants } \\
\text { and personnel (perfor- } \\
\text { mance bias) } \\
\text { All outcomes }\end{array}$ & Low risk & Not possible for a screening trial and not relevant. \\
\hline $\begin{array}{l}\text { Blinding of outcome as- } \\
\text { sessment (detection bias) } \\
\text { All outcomes }\end{array}$ & High risk & $\begin{array}{l}\text { A blinded review was carried out in a subsample of death certificates where } \\
\text { cause of death was breast cancer. The panel much more often stated breast } \\
\text { cancer as cause of death in the control group. }\end{array}$ \\
\hline $\begin{array}{l}\text { Incomplete outcome data } \\
\text { (attrition bias) } \\
\text { All outcomes }\end{array}$ & High risk & $\begin{array}{l}\text { Confusing information and the exact number of randomised women not stat- } \\
\text { ed. }\end{array}$ \\
\hline $\begin{array}{l}\text { Selective reporting (re- } \\
\text { porting bias) }\end{array}$ & High risk & $\begin{array}{l}\text { Confusing information and the exact number of randomised women not stat- } \\
\text { ed. }\end{array}$ \\
\hline Other bias & High risk & $\begin{array}{l}\text { Some women with previous breast cancer in the control group should have } \\
\text { been excluded, which they all were in the screened group. }\end{array}$ \\
\hline
\end{tabular}

Stockholm 1981

Methods Individual randomisation by day of birth; 1-10 and 21-31 in study group and 11-20 in control group (see also text).

Blinding of outcome assessment: not stated.

Participants
$\begin{aligned} & \text { Number of women randomised inconsistently reported (see text). } \\ & \text { Exclusions after randomisation unclear (see text). }\end{aligned}$

Interventions

Single oblique mammography; recalled for conventional three-view if malignancies suspected.

2 cycles (number not predetermined - screening introduced in control group because of results from Kopparberg).

Interval between screens: Circa 2 years; 2.5 years to complete first round and 2.1 to complete second round.

Control group: usual care.

\begin{tabular}{ll} 
Outcomes & $\begin{array}{l}\text { Total mortality. } \\
\text { Breast cancer mortality. } \\
\text { Surgical interventions. }\end{array}$ \\
\hline Notes & Attendance rate: circa $80 \%$.
\end{tabular}


Stockholm 1981 (Continued)

Mammography in control group: $8 \%$ during one year; $25 \%$ in study group during two years previous to screening.

Early systematic screening of control group.

\section{Risk of bias}

\begin{tabular}{lll}
\hline Bias & Authors' judgement & Support for judgement \\
\hline $\begin{array}{l}\text { Random sequence genera- } \\
\text { tion (selection bias) }\end{array}$ & High risk & Day of birth. \\
\hline $\begin{array}{l}\text { Allocation concealment } \\
\text { (selection bias) }\end{array}$ & High risk & Day of birth. \\
\hline $\begin{array}{l}\text { Blinding of participants } \\
\begin{array}{l}\text { and personnel (perfor- } \\
\text { mance bias) } \\
\text { All outcomes }\end{array}\end{array}$ & Low risk & Not possible for a screening trial and not relevant. \\
\hline $\begin{array}{l}\text { Blinding of outcome as- } \\
\text { sessment (detection bias) } \\
\text { All outcomes }\end{array}$ & High risk & Blinding of outcome assessment not stated. \\
\hline $\begin{array}{l}\text { Incomplete outcome data } \\
\text { (attrition bias) } \\
\text { All outcomes }\end{array}$ & High risk & Reported numbers are inconsistent. \\
\hline $\begin{array}{l}\text { Selective reporting (re- } \\
\text { porting bias) }\end{array}$ & High risk & Reported numbers are inconsistent. \\
\hline \begin{tabular}{l} 
Other bias \\
\hline
\end{tabular} & High risk & Reported numbers are inconsistent. \\
\hline
\end{tabular}

Two-County 1977

Methods Stratified cluster randomisation (see Kopparberg 1977 and Östergötland 1978 for details).

Blinding of cause of death assessments in some later updates for use in Swedish meta-analyses.

Participants Women aged $40-74$ years.

(See Kopparberg 1977 and Östergötland 1978 for details).

Interventions $\quad$ See Kopparberg 1977 and Östergötland 1978.

Screened women were encouraged to perform self-examination of the breasts every month.

Control women: usual care.

\begin{tabular}{ll}
\hline Outcomes & See Kopparberg 1977 and Östergötland 1978. \\
\hline Notes & See Kopparberg 1977 and Östergötland 1978. \\
\hline
\end{tabular}

\section{Risk of bias}


Two-County 1977 (Continued)

Random sequence genera- Unclear risk No information. tion (selection bias)

Allocation concealment High risk See text, information inconsistent and incomplete.
(selection bias)

(selection bias)

Blinding of participants Low risk Not possible for a screening trial and not relevant.
and personnel (perfor-
mance bias)
All outcomes
Blinding of outcome as-
High risk
Blinding of outcome assessment not stated.

sessment (detection bias)

All outcomes

Incomplete outcome data High risk Numbers of women, cancers and deaths vary in the reports of the trial.
(attrition bias)

All outcomes

\begin{tabular}{lll}
\hline $\begin{array}{l}\text { Selective reporting (re- } \\
\text { porting bias) }\end{array}$ & High risk & Numbers of women, cancers and deaths vary in the reports of the trial. \\
\hline Other bias & High risk & $\begin{array}{l}\text { Numbers of women, cancers and deaths vary in the reports of the trial, see al- } \\
\text { so main text. }\end{array}$ \\
\hline
\end{tabular}

\section{UK age trial 1991}

$\begin{array}{ll}\text { Methods } & \text { Individual randomisation by computer; randomisation ratio 1:2. } \\ \text { Information on cause of death was obtained from the central register of the National Health Service. }\end{array}$

Women aged $39-41$ years.
Participants
30 and 51 excluded after randomisation.

\begin{tabular}{ll}
\hline Interventions & $\begin{array}{l}\text { Two-view mammography at first screen, and by single mediolateral oblique view thereafter, with recall } \\
\text { for full assessment if an abnormality was suspected. } \\
7 \text { annual screens planned. } \\
\text { Control group: usual care. }\end{array}$ \\
\hline Outcomes & $\begin{array}{l}\text { Total mortality. } \\
\text { Breast cancer mortality. }\end{array}$ \\
\hline Notes & Number of cancers in latest report given per 1000 women-years. \\
\hline Risk of bias & Participation rate: ca 66\% at prevalence screen, below 50\% at 8th screen. \\
\hline Bias & Authors' judgement Support for judgement \\
\hline $\begin{array}{l}\text { Random sequence genera- } \\
\text { tion (selection bias) }\end{array}$ & Low risk Computer. \\
\hline \hline
\end{tabular}


UK age trial 1991 (Continued)

Allocation concealment Low risk Individual randomisation by computer.
(selection bias)

Blinding of participants Low risk Not possible for a screening trial and not relevant.
and personnel (perfor-
mance bias)
All outcomes

\begin{tabular}{lll}
\hline $\begin{array}{l}\text { Blinding of outcome as- } \\
\text { sessment (detection bias) } \\
\text { All outcomes }\end{array}$ & Low risk & $\begin{array}{l}\text { Information on cause of death was obtained from the central register of the } \\
\text { National Health Service. }\end{array}$ \\
\hline $\begin{array}{l}\text { Incomplete outcome data } \\
\begin{array}{l}\text { (attrition bias) } \\
\text { All outcomes }\end{array}\end{array}$ & Low risk & Very few women excluded after randomisation. \\
\hline $\begin{array}{l}\text { Selective reporting (re- } \\
\text { porting bias) }\end{array}$ & Low risk & We found no evidence for this \\
\hline Other bias & Low risk & We found no evidence for this \\
\hline
\end{tabular}

\section{Östergötland 1978}

\begin{tabular}{ll}
\hline Methods & $\begin{array}{l}\text { Stratified cluster randomisation; } 12 \text { blocks (consisting of } 164 \text { parishes in total) were each split into } 2 \\
\text { units of roughly equal size and socio-economic composition; randomisation ratio 1:1 (see also text). } \\
\text { Blinding of outcome assessment not stated. }\end{array}$ \\
\hline
\end{tabular}
Participants Women aged 40 years and above.
24 units with 92,934 women randomised into 47,001 in screening parishes and 45,933 in control parish- es (39,034 versus 37,936 in age group 40-74 years).
No parishes or municipalities excluded.
Women with a previous history of breast cancer were excluded after randomisation; exclusions seem unbiased (see text).

Interventions One-view mammography, mediolateral oblique; women who reported a lump were examined clinically and by complete mammography.

2 screens for women above 70 years, 3 for women originally in age group 40-69 years.

Interval between screens: $2-2.5$ years.

\begin{tabular}{ll}
\hline Outcomes & $\begin{array}{l}\text { Total mortality. } \\
\text { Breast cancer mortality. }\end{array}$ \\
\hline Notes & Attendance rate: ca. $90 \%$ in first round, $80 \%$ in second, very age dependent. \\
& Mammography in control group: $13 \%$. \\
& Early systematic screening of control group.
\end{tabular}

\section{Risk of bias}

Bias Authors' judgement Support for judgement


Östergötland 1978 (Continued)

Random sequence genera- Unclear risk See Two-County 1977. tion (selection bias)

\begin{tabular}{lll}
\hline $\begin{array}{l}\text { Allocation concealment } \\
\text { (selection bias) }\end{array}$ & High risk See Two-County 1977.
\end{tabular}

Blinding of participants $\quad$ Low risk $\quad$ See Two-County 1977.
and personnel (perfor-
mance bias)
All outcomes

Blinding of outcome as- High risk See Two-County 1977.

sessment (detection bias)

All outcomes

\begin{tabular}{ll}
\hline Incomplete outcome data & High risk See Two-County 1977. \\
(attrition bias)
\end{tabular}

All outcomes

\begin{tabular}{lll}
\hline $\begin{array}{l}\text { Selective reporting (re- } \\
\text { porting bias) }\end{array}$ & High risk & See Two-County 1977. \\
\hline Other bias & High risk & See Two-County 1977. \\
\hline
\end{tabular}

\section{Characteristics of excluded studies [ordered by study ID]}

\begin{tabular}{ll}
\hline Study & Reason for exclusion \\
\hline Berglund 2000 & $\begin{array}{l}\text { Multiple risk factor intervention study, with several interventions, including mammography, not } \\
\text { a randomised trial but alternating allocation of birth year cohorts with resulting age differences } \\
\text { at baseline between the two groups; } 50 \text { women died from cancer of 8,712 participants, no data on } \\
\text { breast cancer. }\end{array}$ \\
\hline Dales 1979 & $\begin{array}{l}\text { Multiple risk factor intervention trial, with several interventions, regular mammography was only } \\
\text { one of the interventions and only about } 1000 \text { women were invited for mammography. }\end{array}$ \\
\hline Singapore 1994 & $\begin{array}{l}\text { Singapore Breast Screening Project. Randomised 166,600 women aged 50-64 years, but the only } \\
\text { intervention was the prevalence screen, and exclusions after randomisation occurred only in the } \\
\text { screened group. Previous cancer at any site was an exclusion criterion; more than 1500 women } \\
\text { were excluded from the screened group, 468 because they were already dead. }\end{array}$ \\
\hline
\end{tabular}

DATA AND ANALYSES

Comparison 1. Screening with mammography versus no screening

\begin{tabular}{lllll}
\hline Outcome or subgroup title & No. of studies & $\begin{array}{l}\text { No. of partici- } \\
\text { pants }\end{array}$ & Statistical method & Effect size \\
\hline $\begin{array}{l}\text { 1 Deaths ascribed to breast cancer, } 7 \\
\text { years follow up }\end{array}$ & 11 & 616327 & $\begin{array}{l}\text { Risk Ratio (M-H, Fixed, 95\% } \\
\text { Cl) }\end{array}$ & $0.81[0.72,0.90]$ \\
\hline
\end{tabular}




\begin{tabular}{|c|c|c|c|c|}
\hline Outcome or subgroup title & No. of studies & $\begin{array}{l}\text { No. of partici- } \\
\text { pants }\end{array}$ & Statistical method & Effect size \\
\hline 1.1 Adequately randomised trials & 4 & 292958 & $\begin{array}{l}\text { Risk Ratio (M-H, Fixed, 95\% } \\
\mathrm{Cl})\end{array}$ & $0.93[0.79,1.09]$ \\
\hline 1.2 Suboptimally randomised trials & 7 & 323369 & $\begin{array}{l}\text { Risk Ratio (M-H, Fixed, 95\% } \\
\mathrm{Cl} \text { ) }\end{array}$ & $0.71[0.61,0.83]$ \\
\hline $\begin{array}{l}2 \text { Deaths ascribed to breast cancer, } 13 \\
\text { years follow up }\end{array}$ & 9 & 599090 & $\begin{array}{l}\text { Risk Ratio (M-H, Fixed, 95\% } \\
\mathrm{Cl})\end{array}$ & $0.81[0.74,0.87]$ \\
\hline 2.1 Adequately randomised trials & 4 & 292153 & $\begin{array}{l}\text { Risk Ratio (M-H, Fixed, 95\% } \\
\mathrm{CI})\end{array}$ & $0.90[0.79,1.02]$ \\
\hline 2.2 Suboptimally randomised trials & 5 & 306937 & $\begin{array}{l}\text { Risk Ratio (M-H, Fixed, 95\% } \\
\mathrm{CI})\end{array}$ & $0.75[0.67,0.83]$ \\
\hline $\begin{array}{l}3 \text { Deaths ascribed to breast cancer, } 7 \\
\text { years follow up, women below } 50 \text { years } \\
\text { of age (Malmö 55) }\end{array}$ & 9 & 356368 & $\begin{array}{l}\text { Risk Ratio (M-H, Fixed, 95\% } \\
\mathrm{CI})\end{array}$ & $0.89[0.77,1.04]$ \\
\hline 3.1 Adequately randomised trials & 3 & 227333 & $\begin{array}{l}\text { Risk Ratio (M-H, Fixed, 95\% } \\
\mathrm{Cl})\end{array}$ & $0.94[0.78,1.14]$ \\
\hline 3.2 Suboptimally randomised trials & 6 & 129035 & $\begin{array}{l}\text { Risk Ratio (M-H, Fixed, 95\% } \\
\mathrm{Cl})\end{array}$ & $0.81[0.63,1.05]$ \\
\hline $\begin{array}{l}4 \text { Deaths ascribed to breast cancer, } 7 \\
\text { years follow up, women at least } 50 \text { years } \\
\text { of age (Malmö 55) }\end{array}$ & 7 & 261044 & $\begin{array}{l}\text { Risk Ratio (M-H, Fixed, 95\% } \\
\mathrm{Cl})\end{array}$ & $0.72[0.62,0.85]$ \\
\hline 4.1 Adequately randomised trials & 2 & 65625 & $\begin{array}{l}\text { Risk Ratio (M-H, Fixed, 95\% } \\
\mathrm{CI})\end{array}$ & $0.88[0.64,1.20]$ \\
\hline 4.2 Suboptimally randomised trials & 5 & 195419 & $\begin{array}{l}\text { Risk Ratio (M-H, Fixed, 95\% } \\
\mathrm{Cl})\end{array}$ & $0.67[0.56,0.81]$ \\
\hline $\begin{array}{l}5 \text { Deaths ascribed to breast cancer, } 13 \\
\text { years follow up, women below } 50 \text { years } \\
\text { of age }\end{array}$ & 8 & 329511 & $\begin{array}{l}\text { Risk Ratio (M-H, Fixed, 95\% } \\
\mathrm{Cl})\end{array}$ & $0.84[0.73,0.96]$ \\
\hline 5.1 Adequately randomised trials & 3 & 218697 & $\begin{array}{l}\text { Risk Ratio (M-H, Fixed, 95\% } \\
\mathrm{Cl} \text { ) }\end{array}$ & $0.87[0.73,1.03]$ \\
\hline 5.2 Suboptimally randomised trials & 5 & 110814 & $\begin{array}{l}\text { Risk Ratio (M-H, Fixed, 95\% } \\
\mathrm{Cl})\end{array}$ & $0.80[0.64,0.98]$ \\
\hline $\begin{array}{l}6 \text { Deaths ascribed to breast cancer, } 13 \\
\text { years follow up, women at least } 50 \text { years } \\
\text { of age }\end{array}$ & 7 & 268874 & $\begin{array}{l}\text { Risk Ratio (M-H, Fixed, 95\% } \\
\mathrm{CI})\end{array}$ & $0.77[0.69,0.86]$ \\
\hline 6.1 Adequately randomised trials & 2 & 74261 & $\begin{array}{l}\text { Risk Ratio (M-H, Fixed, 95\% } \\
\mathrm{Cl})\end{array}$ & $0.94[0.77,1.15]$ \\
\hline 6.2 Suboptimally randomised trials & 5 & 194613 & $\begin{array}{l}\text { Risk Ratio (M-H, Fixed, 95\% } \\
\mathrm{Cl} \text { ) }\end{array}$ & $0.70[0.62,0.80]$ \\
\hline
\end{tabular}




\begin{tabular}{|c|c|c|c|c|}
\hline Outcome or subgroup title & No. of studies & $\begin{array}{l}\text { No. of partici- } \\
\text { pants }\end{array}$ & Statistical method & Effect size \\
\hline $\begin{array}{l}7 \text { Deaths ascribed to any cancer, all } \\
\text { women }\end{array}$ & 6 & & $\begin{array}{l}\text { Risk Ratio (M-H, Fixed, 95\% } \\
\mathrm{Cl})\end{array}$ & Subtotals only \\
\hline 7.1 Adequately randomised trials & 3 & 132118 & $\begin{array}{l}\text { Risk Ratio (M-H, Fixed, 95\% } \\
\text { Cl) }\end{array}$ & $1.02[0.95,1.10]$ \\
\hline $\begin{array}{l}7.2 \text { Suboptimally randomised trials (un- } \\
\text { reliable estimates) }\end{array}$ & 3 & 195871 & $\begin{array}{l}\text { Risk Ratio (M-H, Fixed, 95\% } \\
\text { Cl) }\end{array}$ & $0.99[0.93,1.06]$ \\
\hline 8 Overall mortality, 7 years follow up & 11 & & $\begin{array}{l}\text { Risk Ratio (M-H, Fixed, 95\% } \\
\mathrm{Cl})\end{array}$ & Subtotals only \\
\hline 8.1 Adequately randomised trials & 4 & 292958 & $\begin{array}{l}\text { Risk Ratio (M-H, Fixed, 95\% } \\
\mathrm{Cl} \text { ) }\end{array}$ & $0.98[0.94,1.03]$ \\
\hline $\begin{array}{l}8.2 \text { Suboptimally randomised trials (un- } \\
\text { reliable estimates) }\end{array}$ & 7 & 324977 & $\begin{array}{l}\text { Risk Ratio (M-H, Fixed, 95\% } \\
\mathrm{Cl} \text { ) }\end{array}$ & $0.99[0.96,1.02]$ \\
\hline 9 Overall mortality, 13 years follow up & 8 & & $\begin{array}{l}\text { Risk Ratio (M-H, Fixed, 95\% } \\
\mathrm{Cl} \text { ) }\end{array}$ & Subtotals only \\
\hline 9.1 Adequately randomised trials & 4 & 292958 & $\begin{array}{l}\text { Risk Ratio (M-H, Fixed, 95\% } \\
\mathrm{Cl})\end{array}$ & $0.99[0.95,1.03]$ \\
\hline $\begin{array}{l}9.2 \text { Suboptimally randomised trials (un- } \\
\text { reliable estimates) }\end{array}$ & 4 & 244868 & $\begin{array}{l}\text { Risk Ratio (M-H, Fixed, 95\% } \\
\mathrm{Cl} \text { ) }\end{array}$ & $0.99[0.97,1.01]$ \\
\hline $\begin{array}{l}10 \text { Overall mortality, } 7 \text { years follow up, } \\
\text { women below } 50 \text { years of age }\end{array}$ & 7 & & $\begin{array}{l}\text { Risk Ratio (M-H, Fixed, 95\% } \\
\mathrm{Cl} \text { ) }\end{array}$ & Subtotals only \\
\hline 10.1 Adequately randomised trials & 2 & 211270 & $\begin{array}{l}\text { Risk Ratio (M-H, Fixed, 95\% } \\
\mathrm{Cl})\end{array}$ & $0.97[0.90,1.04]$ \\
\hline $\begin{array}{l}10.2 \text { Suboptimally randomised trials } \\
\text { (unreliable estimates) }\end{array}$ & 5 & 99656 & $\begin{array}{l}\text { Risk Ratio (M-H, Fixed, 95\% } \\
\mathrm{Cl} \text { ) }\end{array}$ & $1.07[0.98,1.16]$ \\
\hline $\begin{array}{l}11 \text { Overall mortality, } 7 \text { years follow up, } \\
\text { women at least } 50 \text { years of age }\end{array}$ & 5 & & $\begin{array}{l}\text { Risk Ratio (M-H, Fixed, 95\% } \\
\mathrm{Cl})\end{array}$ & Subtotals only \\
\hline 11.1 Adequately randomised trials & 1 & 39405 & $\begin{array}{l}\text { Risk Ratio (M-H, Fixed, 95\% } \\
\mathrm{Cl})\end{array}$ & $1.01[0.85,1.20]$ \\
\hline $\begin{array}{l}\text { 11.2 Suboptimally randomised trials } \\
\text { (unreliable estimates) }\end{array}$ & 4 & 161519 & $\begin{array}{l}\text { Risk Ratio (M-H, Fixed, 95\% } \\
\mathrm{Cl} \text { ) }\end{array}$ & $0.97[0.94,1.00]$ \\
\hline $\begin{array}{l}12 \text { Overall mortality, } 13 \text { years follow up, } \\
\text { women below } 50 \text { years of age }\end{array}$ & 6 & & $\begin{array}{l}\text { Risk Ratio (M-H, Fixed, 95\% } \\
\mathrm{Cl})\end{array}$ & Subtotals only \\
\hline 12.1 Adequately randomised trials & 3 & 219324 & $\begin{array}{l}\text { Risk Ratio (M-H, Fixed, 95\% } \\
\mathrm{Cl})\end{array}$ & $0.98[0.92,1.04]$ \\
\hline $\begin{array}{l}\text { 12.2 Suboptimally randomised trials } \\
\text { (unreliable estimates) }\end{array}$ & 3 & 61344 & $\begin{array}{l}\text { Risk Ratio (M-H, Fixed, 95\% } \\
\text { Cl) }\end{array}$ & $1.00[0.92,1.10]$ \\
\hline
\end{tabular}




\begin{tabular}{|c|c|c|c|c|}
\hline Outcome or subgroup title & No. of studies & $\begin{array}{l}\text { No. of partici- } \\
\text { pants }\end{array}$ & Statistical method & Effect size \\
\hline $\begin{array}{l}13 \text { Overall mortality, } 13 \text { years follow up, } \\
\text { women at least } 50 \text { years of age }\end{array}$ & 4 & & $\begin{array}{l}\text { Risk Ratio (M-H, Fixed, 95\% } \\
\mathrm{Cl})\end{array}$ & Subtotals only \\
\hline 13.1 Adequately randomised trials & 2 & 73634 & $\begin{array}{l}\text { Risk Ratio (M-H, Fixed, 95\% } \\
\mathrm{Cl})\end{array}$ & $1.00[0.95,1.04]$ \\
\hline $\begin{array}{l}\text { 13.2 Suboptimally randomised trials } \\
\text { (unreliable estimates) }\end{array}$ & 2 & 98261 & $\begin{array}{l}\text { Risk Ratio (M-H, Fixed, 95\% } \\
\mathrm{Cl} \text { ) }\end{array}$ & $0.99[0.97,1.02]$ \\
\hline $\begin{array}{l}14 \text { Number of mastectomies and } \\
\text { lumpectomies }\end{array}$ & 5 & 250479 & $\begin{array}{l}\text { Risk Ratio (M-H, Fixed, 95\% } \\
\mathrm{CI})\end{array}$ & $1.35[1.26,1.44]$ \\
\hline 14.1 Adequately randomised trials & 3 & 132321 & $\begin{array}{l}\text { Risk Ratio (M-H, Fixed, 95\% } \\
\mathrm{Cl})\end{array}$ & $1.31[1.22,1.42]$ \\
\hline 14.2 Suboptimally randomised trials & 2 & 118158 & $\begin{array}{l}\text { Risk Ratio (M-H, Fixed, 95\% } \\
\mathrm{Cl} \text { ) }\end{array}$ & $1.42[1.26,1.61]$ \\
\hline 15 Number of mastectomies & 5 & 250479 & $\begin{array}{l}\text { Risk Ratio (M-H, Fixed, 95\% } \\
\mathrm{CI})\end{array}$ & $1.20[1.11,1.30]$ \\
\hline 15.1 Adequately randomised trials & 3 & 132321 & $\begin{array}{l}\text { Risk Ratio (M-H, Fixed, 95\% } \\
\mathrm{Cl} \text { ) }\end{array}$ & $1.20[1.08,1.32]$ \\
\hline 15.2 Suboptimally randomised trials & 2 & 118158 & $\begin{array}{l}\text { Risk Ratio (M-H, Fixed, 95\% } \\
\mathrm{Cl} \text { ) }\end{array}$ & $1.21[1.06,1.38]$ \\
\hline 16 Number treated with radiotherapy & 2 & 100383 & $\begin{array}{l}\text { Risk Ratio (M-H, Fixed, 95\% } \\
\mathrm{Cl})\end{array}$ & $1.32[1.16,1.50]$ \\
\hline 16.1 Adequately randomised trials & 1 & 42486 & $\begin{array}{l}\text { Risk Ratio (M-H, Fixed, 95\% } \\
\mathrm{Cl})\end{array}$ & $1.24[1.04,1.49]$ \\
\hline 16.2 Suboptimally randomised trials & 1 & 57897 & $\begin{array}{l}\text { Risk Ratio (M-H, Fixed, 95\% } \\
\mathrm{Cl} \text { ) }\end{array}$ & $1.40[1.17,1.69]$ \\
\hline 17 Number treated with chemotherapy & 2 & 100383 & $\begin{array}{l}\text { Risk Ratio (M-H, Fixed, 95\% } \\
\mathrm{Cl} \text { ) }\end{array}$ & $0.96[0.78,1.19]$ \\
\hline 17.1 Adequately randomised trials & 1 & 42486 & $\begin{array}{l}\text { Risk Ratio (M-H, Fixed, 95\% } \\
\mathrm{Cl})\end{array}$ & $0.63[0.39,1.04]$ \\
\hline 17.2 Suboptimally randomised trials & 1 & 57897 & $\begin{array}{l}\text { Risk Ratio (M-H, Fixed, 95\% } \\
\mathrm{Cl})\end{array}$ & $1.06[0.84,1.34]$ \\
\hline $\begin{array}{l}18 \text { Number treated with hormone thera- } \\
\text { py }\end{array}$ & 2 & 100383 & $\begin{array}{l}\text { Risk Ratio (M-H, Fixed, 95\% } \\
\mathrm{Cl} \text { ) }\end{array}$ & $0.73[0.55,0.96]$ \\
\hline 18.1 Adequately randomised trials & 1 & 42486 & $\begin{array}{l}\text { Risk Ratio (M-H, Fixed, 95\% } \\
\mathrm{Cl})\end{array}$ & $0.81[0.60,1.08]$ \\
\hline 18.2 Suboptimally randomised trials & 1 & 57897 & $\begin{array}{l}\text { Risk Ratio (M-H, Fixed, 95\% } \\
\mathrm{Cl})\end{array}$ & $0.30[0.12,0.72]$ \\
\hline
\end{tabular}




\begin{tabular}{|c|c|c|c|c|}
\hline Outcome or subgroup title & No. of studies & $\begin{array}{l}\text { No. of partici- } \\
\text { pants }\end{array}$ & Statistical method & Effect size \\
\hline $\begin{array}{l}19 \text { Mortality among breast cancer pa- } \\
\text { tients in the Two-County study, } 7 \text { years } \\
\text { follow up }\end{array}$ & 2 & & $\begin{array}{l}\text { Risk Ratio (M-H, Fixed, 95\% } \\
\text { CI) }\end{array}$ & Subtotals only \\
\hline $\begin{array}{l}19.1 \text { Mortality from cancers other than } \\
\text { breast cancer }\end{array}$ & 2 & 2063 & $\begin{array}{l}\text { Risk Ratio (M-H, Fixed, 95\% } \\
\mathrm{Cl})\end{array}$ & $2.42[1.00,5.85]$ \\
\hline $\begin{array}{l}19.2 \text { Mortality from causes other than } \\
\text { breast cancer }\end{array}$ & 2 & 2063 & $\begin{array}{l}\text { Risk Ratio (M-H, Fixed, 95\% } \\
\mathrm{Cl})\end{array}$ & $1.37[0.93,2.04]$ \\
\hline 20 Results for biased trial & 1 & & $\begin{array}{l}\text { Risk Ratio (M-H, Fixed, 95\% } \\
\mathrm{Cl})\end{array}$ & $\begin{array}{l}\text { Totals not select- } \\
\text { ed }\end{array}$ \\
\hline $\begin{array}{l}20.1 \text { Deaths ascribed to breast cancer, } 7 \\
\text { years follow up }\end{array}$ & 1 & & $\begin{array}{l}\text { Risk Ratio (M-H, Fixed, 95\% } \\
\mathrm{Cl})\end{array}$ & $0.0[0.0,0.0]$ \\
\hline $\begin{array}{l}20.2 \text { Deaths ascribed to breast cancer, } \\
13 \text { years follow up }\end{array}$ & 1 & & $\begin{array}{l}\text { Risk Ratio (M-H, Fixed, 95\% } \\
\mathrm{Cl})\end{array}$ & $0.0[0.0,0.0]$ \\
\hline $\begin{array}{l}20.3 \text { Deaths ascribed to breast cancer, } 7 \\
\text { years follow up, younger women (below } \\
50 \text { years of age) }\end{array}$ & 1 & & $\begin{array}{l}\text { Risk Ratio (M-H, Fixed, 95\% } \\
\mathrm{Cl})\end{array}$ & $0.0[0.0,0.0]$ \\
\hline $\begin{array}{l}20.4 \text { Deaths ascribed to breast cancer, } 7 \\
\text { years follow up, elderly women (at least } \\
50 \text { years of age) }\end{array}$ & 1 & & $\begin{array}{l}\text { Risk Ratio (M-H, Fixed, 95\% } \\
\mathrm{Cl})\end{array}$ & $0.0[0.0,0.0]$ \\
\hline $\begin{array}{l}20.5 \text { Deaths ascribed to breast cancer, } \\
13 \text { years follow up, younger women (be- } \\
\text { low } 50 \text { years of age) }\end{array}$ & 1 & & $\begin{array}{l}\text { Risk Ratio (M-H, Fixed, 95\% } \\
\mathrm{Cl})\end{array}$ & $0.0[0.0,0.0]$ \\
\hline $\begin{array}{l}20.6 \text { Deaths ascribed to breast cancer, } \\
13 \text { years follow up, elderly women (at } \\
\text { least } 50 \text { years of age) }\end{array}$ & 1 & & $\begin{array}{l}\text { Risk Ratio (M-H, Fixed, 95\% } \\
\mathrm{Cl} \text { ) }\end{array}$ & $0.0[0.0,0.0]$ \\
\hline 20.7 Overall mortality, 7 years follow up & 1 & & $\begin{array}{l}\text { Risk Ratio (M-H, Fixed, 95\% } \\
\mathrm{Cl})\end{array}$ & $0.0[0.0,0.0]$ \\
\hline 20.8 Number treated with radiotherapy & 1 & & $\begin{array}{l}\text { Risk Ratio (M-H, Fixed, 95\% } \\
\mathrm{Cl})\end{array}$ & $0.0[0.0,0.0]$ \\
\hline 21 Number of cancers & 7 & 512246 & $\begin{array}{l}\text { Risk Ratio (M-H, Fixed, 95\% } \\
\mathrm{Cl})\end{array}$ & $1.29[1.23,1.35]$ \\
\hline $\begin{array}{l}21.1 \text { Adequately randomised trials (after } \\
7-9 \text { years) }\end{array}$ & 4 & 292979 & $\begin{array}{l}\text { Risk Ratio (M-H, Fixed, 95\% } \\
\mathrm{Cl})\end{array}$ & $1.25[1.18,1.34]$ \\
\hline $\begin{array}{l}21.2 \text { Suboptimally randomised trials } \\
\text { (before control group screen) }\end{array}$ & 3 & 219267 & $\begin{array}{l}\text { Risk Ratio (M-H, Fixed, 95\% } \\
\mathrm{Cl})\end{array}$ & $1.33[1.24,1.44]$ \\
\hline
\end{tabular}


Analysis 1.1. Comparison 1 Screening with mammography versus no screening, Outcome 1 Deaths ascribed to breast cancer, 7 years follow up.

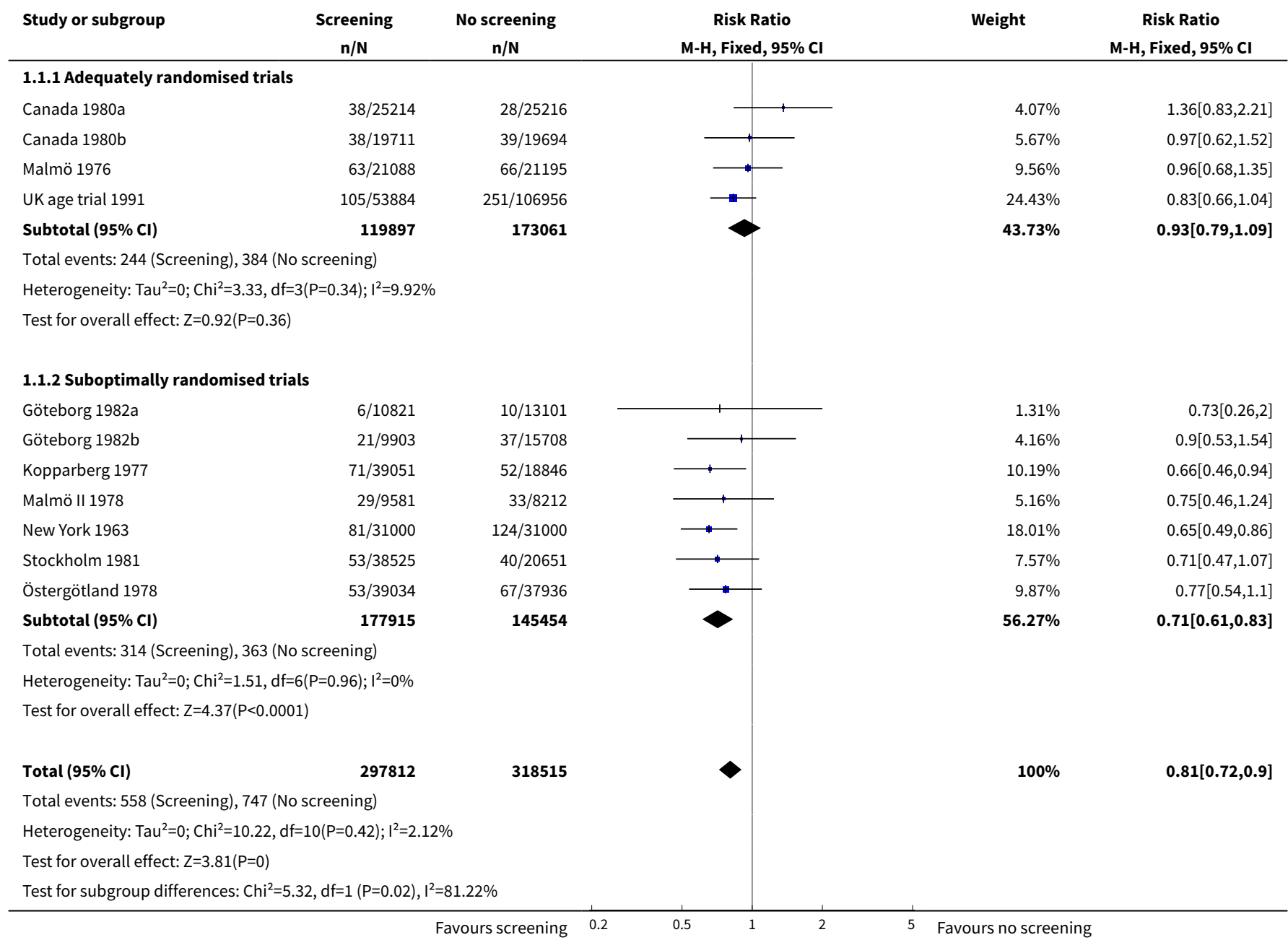

Analysis 1.2. Comparison 1 Screening with mammography versus no screening, Outcome 2 Deaths ascribed to breast cancer, 13 years follow up.

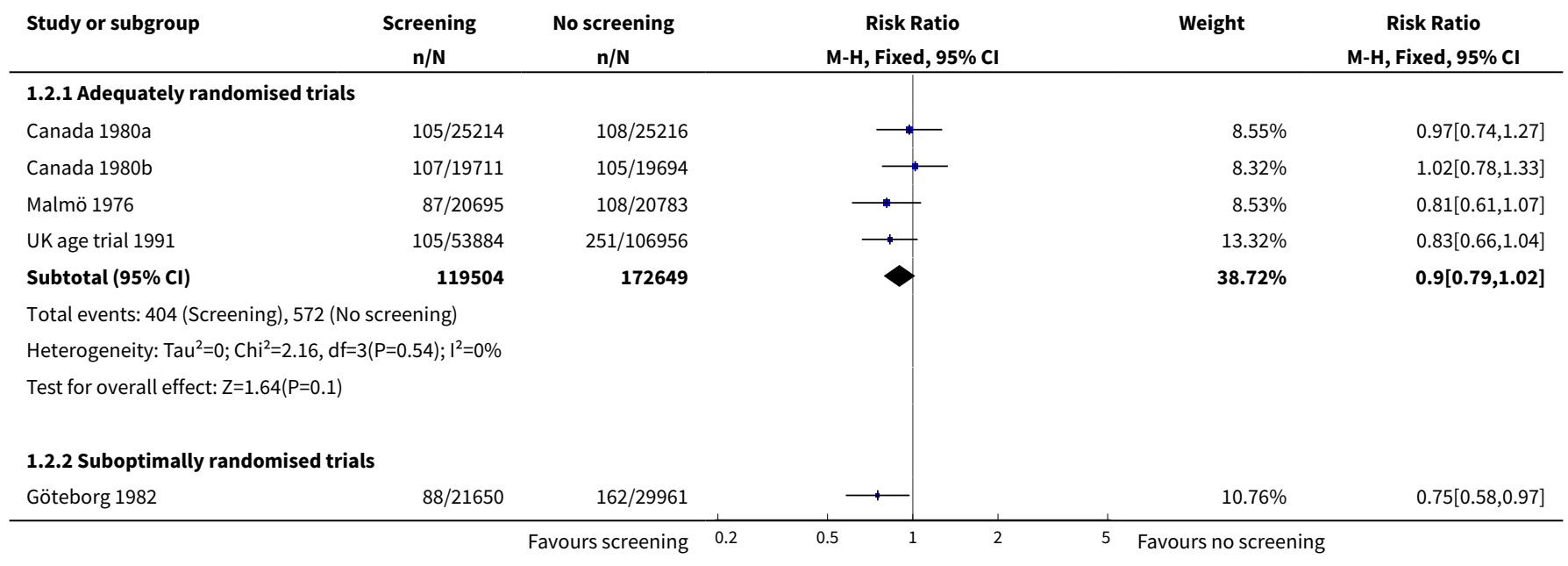




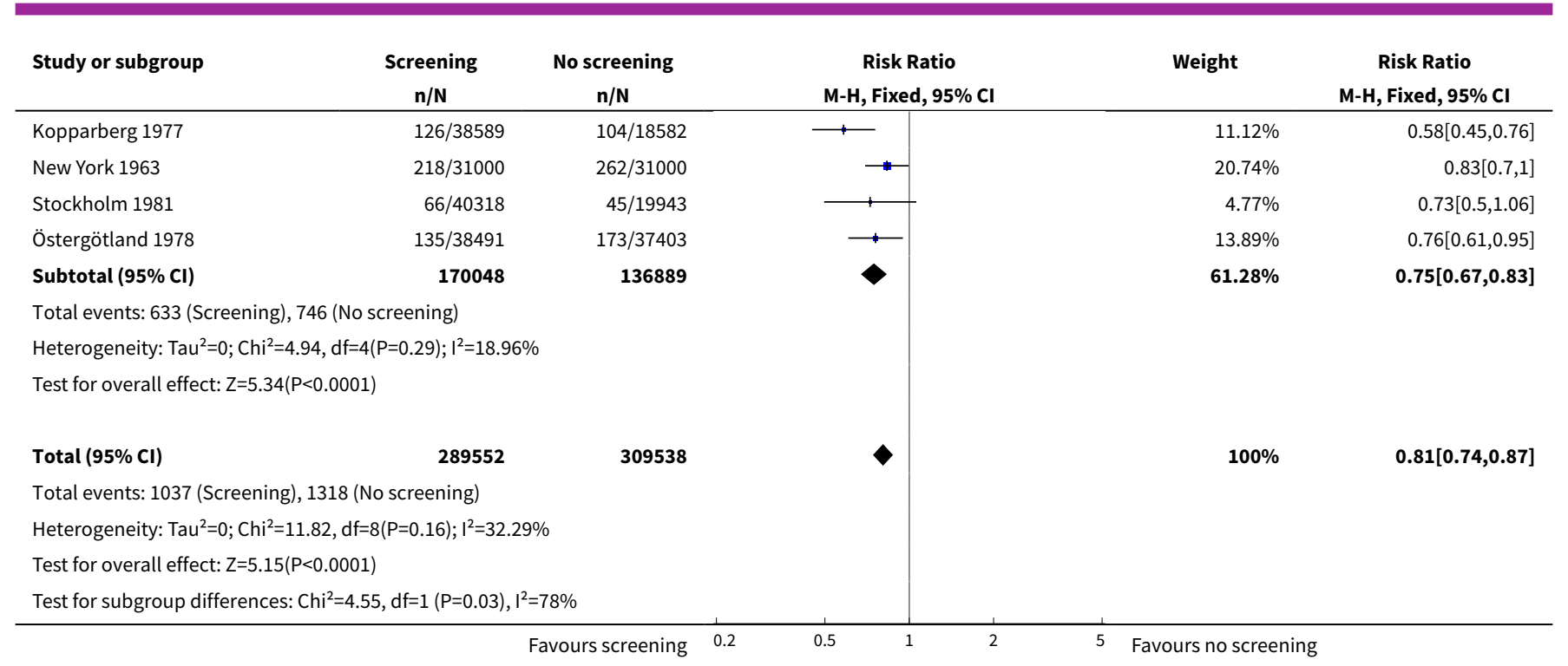

Analysis 1.3. Comparison 1 Screening with mammography versus no screening, Outcome 3
Deaths ascribed to breast cancer, 7 years follow up, women below 50 years of age (Malmö 55).

Screening

$\mathbf{n} / \mathbf{N}$

1.3.1 Adequately randomised trials

Canada 1980a

Malmö 1976

UK age trial 1991

Subtotal $(95 \% \mathrm{Cl})$

Total events: 171 (Screening), 301 (No screening)

Heterogeneity: $\mathrm{Tau}^{2}=0 ; \mathrm{Chi}^{2}=4.55, \mathrm{df}=2(\mathrm{P}=0.1) ; \mathrm{I}^{2}=56.01 \%$

Test for overall effect: $Z=0.59(P=0.56)$

1.3.2 Suboptimally randomised trials

Göteborg 1982a

Kopparberg 1977

Malmö II 1978

New York 1963

Stockholm 1981

Östergötland 1978

Subtotal $(95 \% \mathrm{CI})$

$38 / 25214$

$28 / 7981$

$105 / 53884$

87079

Total events: 117 (Screening), 121 (No screening)

Heterogeneity: $\mathrm{Tau}^{2}=0 ; \mathrm{Chi}^{2}=0.72, \mathrm{df}=5(\mathrm{P}=0.98) ; \mathrm{I}^{2}=0 \%$

Test for overall effect: $Z=1.59(P=0.11)$

\section{Total $(95 \% \mathrm{Cl})$}

157109

Total events: 288 (Screening), 422 (No screening)

Heterogeneity: $\mathrm{Tau}^{2}=0 ; \mathrm{Chi}^{2}=6.14, \mathrm{df}=8(\mathrm{P}=0.63) ; \mathrm{I}^{2}=0 \%$

Test for overall effect: $Z=1.42(P=0.16)$

Test for subgroup differences: $\mathrm{Chi}^{2}=0.85, \mathrm{df}=1(\mathrm{P}=0.36), \mathrm{I}^{2}=0 \%$
No screening

$\mathbf{n} / \mathbf{N}$

Risk Ratio

M-H, Fixed, $95 \% \mathrm{Cl}$

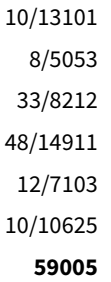

$28 / 25216$

$22 / 8082$

251/106956

140254

$\begin{array}{rr}6 / 10821 & 10 / 13101 \\ 12 / 9625 & 8 / 5053 \\ 29 / 9581 & 33 / 8212 \\ 39 / 14849 & 48 / 14911 \\ 20 / 14842 & 12 / 7103 \\ 11 / 10312 & 10 / 10625 \\ \mathbf{7 0 0 3 0} & \mathbf{5 9 0 0 5}\end{array}$

*

$2.61 \%$

$3.02 \%$

$10.24 \%$

$13.8 \%$

$4.68 \%$

$2.84 \%$

$37.18 \%$

Risk Ratio

M-H, Fixed, 95\% CI

\section{$1.36[0.83,2.21]$ \\ $1.29[0.74,2.25]$ \\ $0.83[0.66,1.04]$ \\ $0.94[0.78,1.14]$}


Analysis 1.4. Comparison 1 Screening with mammography versus no screening, Outcome 4 Deaths ascribed to breast cancer, 7 years follow up, women at least 50 years of age (Malmö 55).

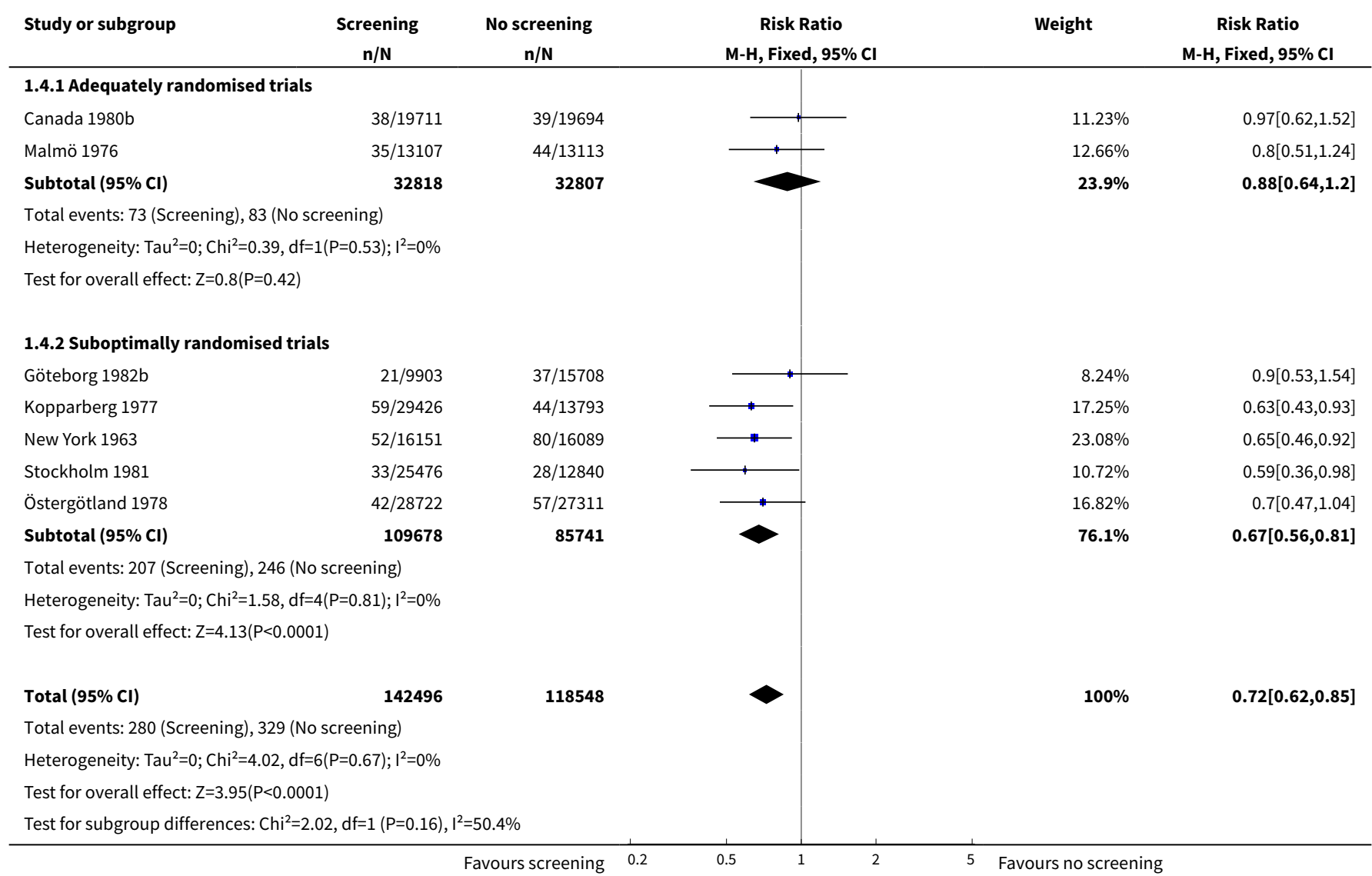

\section{Analysis 1.5. Comparison 1 Screening with mammography versus no screening, Outcome 5 Deaths ascribed to breast cancer, 13 years follow up, women below 50 years of age.}

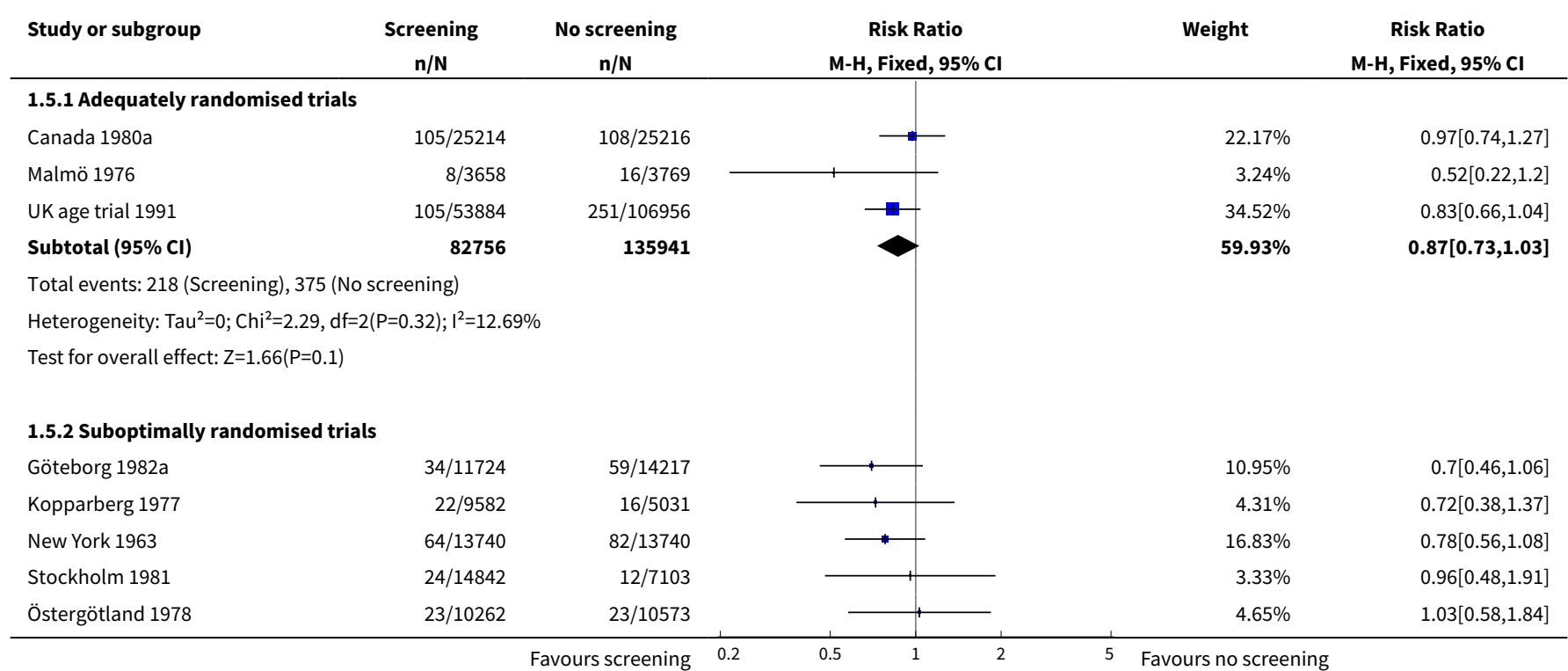




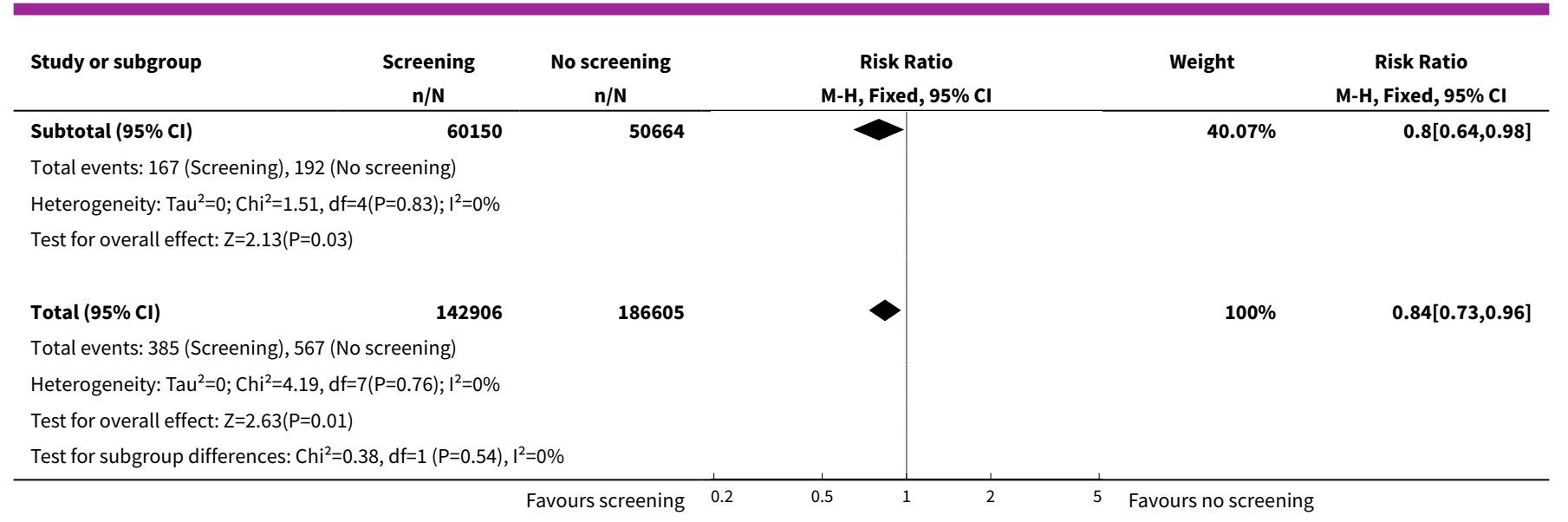

\section{Analysis 1.6. Comparison 1 Screening with mammography versus no screening, Outcome 6 Deaths ascribed to breast cancer, 13 years follow up, women at least 50 years of age.}

\begin{tabular}{|c|c|c|c|c|c|}
\hline Study or subgroup & $\begin{array}{c}\text { Screening } \\
\mathrm{n} / \mathrm{N}\end{array}$ & $\begin{array}{c}\text { No screening } \\
n / N\end{array}$ & $\begin{array}{c}\text { Risk Ratio } \\
\text { M-H, Fixed, 95\% Cl }\end{array}$ & Weight & $\begin{array}{c}\text { Risk Ratio } \\
\text { M-H, Fixed, 95\% Cl }\end{array}$ \\
\hline \multicolumn{6}{|c|}{ 1.6.1 Adequately randomised trials } \\
\hline Canada 1980b & $107 / 19711$ & $105 / 19694$ & $\rightarrow$ & $14.5 \%$ & $1.02[0.78,1.33]$ \\
\hline Malmö 1976 & $79 / 17430$ & $92 / 17426$ & $\longrightarrow$ & $12.7 \%$ & $0.86[0.64,1.16]$ \\
\hline Subtotal $(95 \% \mathrm{CI})$ & 37141 & 37120 & & $27.2 \%$ & $0.94[0.77,1.15]$ \\
\hline \multicolumn{6}{|c|}{ Total events: 186 (Screening), 197 (No screening) } \\
\hline \multicolumn{6}{|c|}{ Test for overall effect: $Z=0.57(P=0.57)$} \\
\hline \multicolumn{6}{|c|}{ 1.6.2 Suboptimally randomised trials } \\
\hline Göteborg 1982b & $54 / 9926$ & $103 / 15744$ & $\rightarrow$ & $11 \%$ & $0.83[0.6,1.15]$ \\
\hline Kopparberg 1977 & $104 / 29007$ & $88 / 13551$ & $\longrightarrow$ & $16.56 \%$ & $0.55[0.42,0.73]$ \\
\hline New York 1963 & $101 / 16505$ & $130 / 16505$ & & $17.95 \%$ & $0.78[0.6,1.01]$ \\
\hline Östergötland 1978 & $112 / 28229$ & $150 / 26830$ & $\longrightarrow$ & $21.23 \%$ & $0.71[0.56,0.91]$ \\
\hline Subtotal $(95 \% \mathrm{CI})$ & 109143 & 85470 & & $72.8 \%$ & $0.7[0.62,0.8]$ \\
\hline \multicolumn{6}{|c|}{ Total events: 413 (Screening), 504 (No screening) } \\
\hline \multicolumn{6}{|c|}{ Heterogeneity: $\mathrm{Tau}^{2}=0 ; \mathrm{Chi}^{2}=4.54, \mathrm{df}=4(\mathrm{P}=0.34) ; \mathrm{I}^{2}=11.82 \%$} \\
\hline \multicolumn{6}{|c|}{ Test for overall effect: $Z=5.28(P<0.0001)$} \\
\hline Total $(95 \% \mathrm{Cl})$ & 146284 & 122590 & & $100 \%$ & $0.77[0.69,0.86]$ \\
\hline \multicolumn{6}{|c|}{ Total events: 599 (Screening), 701 (No screening) } \\
\hline \multicolumn{6}{|c|}{ Heterogeneity: $\mathrm{Tau}^{2}=0 ; \mathrm{Chi}^{2}=11.22, \mathrm{df}=6(\mathrm{P}=0.08) ; \mathrm{I}^{2}=46.54 \%$} \\
\hline \multicolumn{6}{|c|}{ Test for overall effect: $Z=4.73(P<0.0001)$} \\
\hline Test for subgroup dif & , $\mathrm{df}=1(\mathrm{P}=0.02)$ & $2.84 \%$ & & & \\
\hline
\end{tabular}


Analysis 1.7. Comparison 1 Screening with mammography versus no screening, Outcome 7 Deaths ascribed to any cancer, all women.

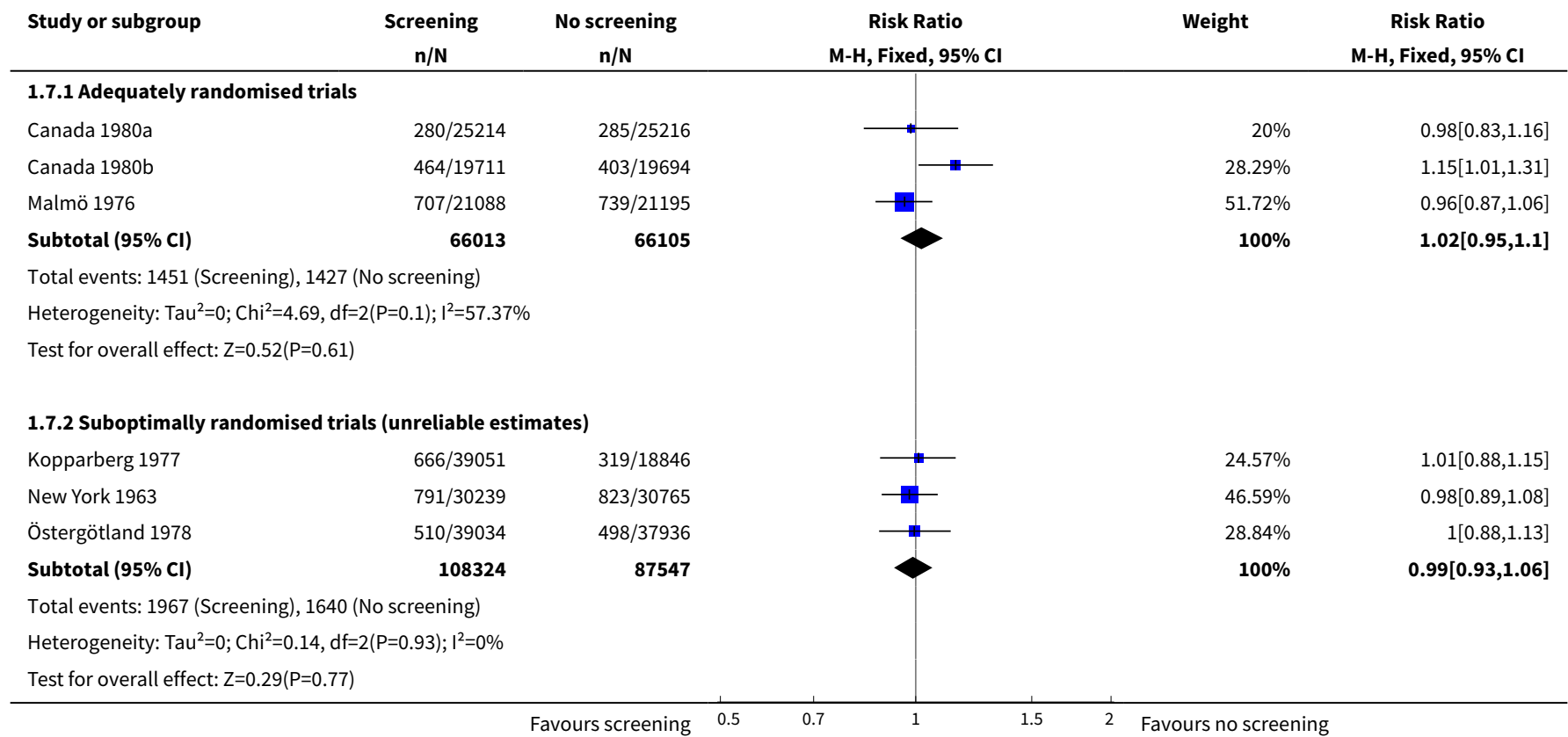

\section{Analysis 1.8. Comparison 1 Screening with mammography versus no screening, Outcome 8 Overall mortality, 7 years follow up.}

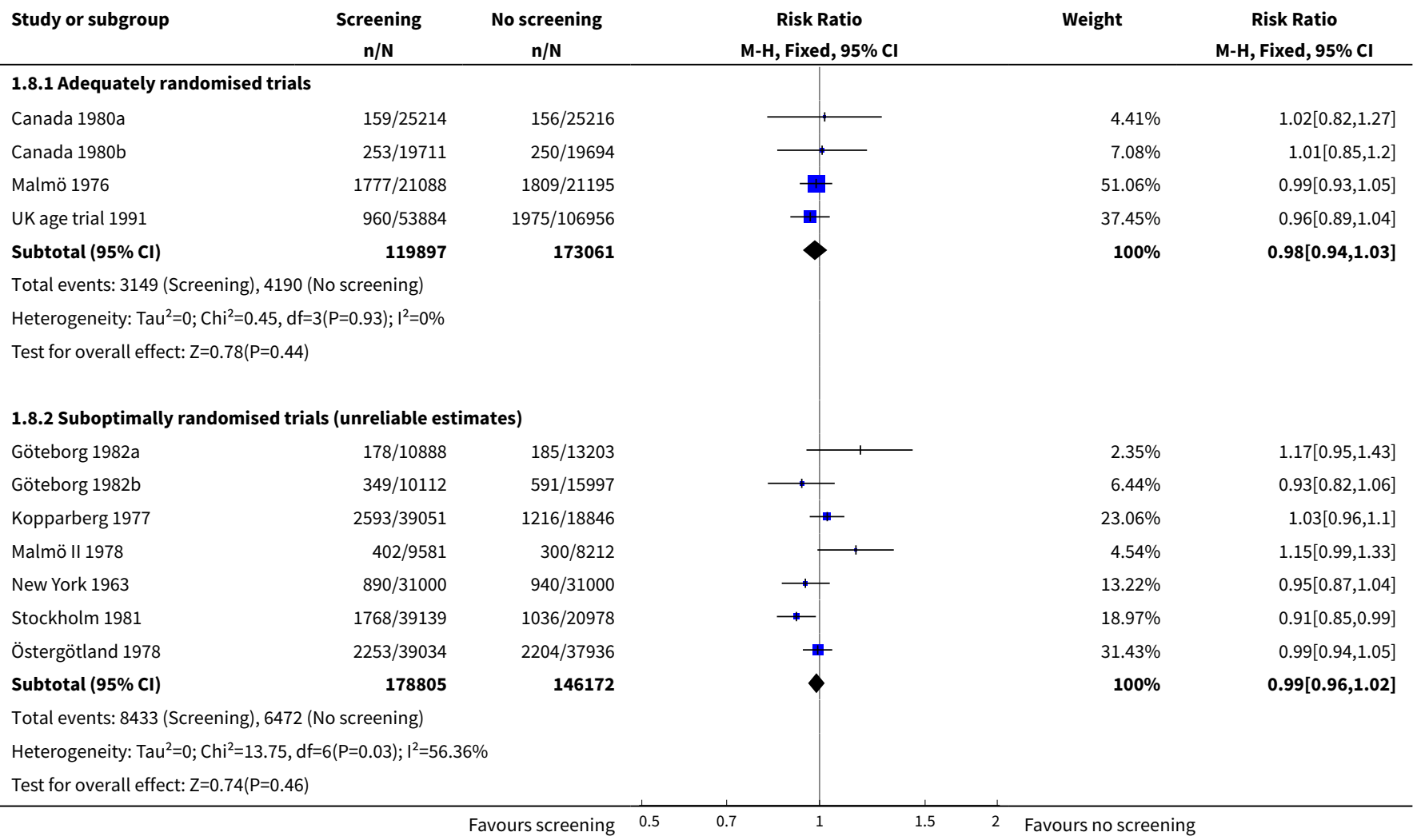




\section{Analysis 1.9. Comparison 1 Screening with mammography versus no screening, Outcome 9 Overall mortality, 13 years follow up.}

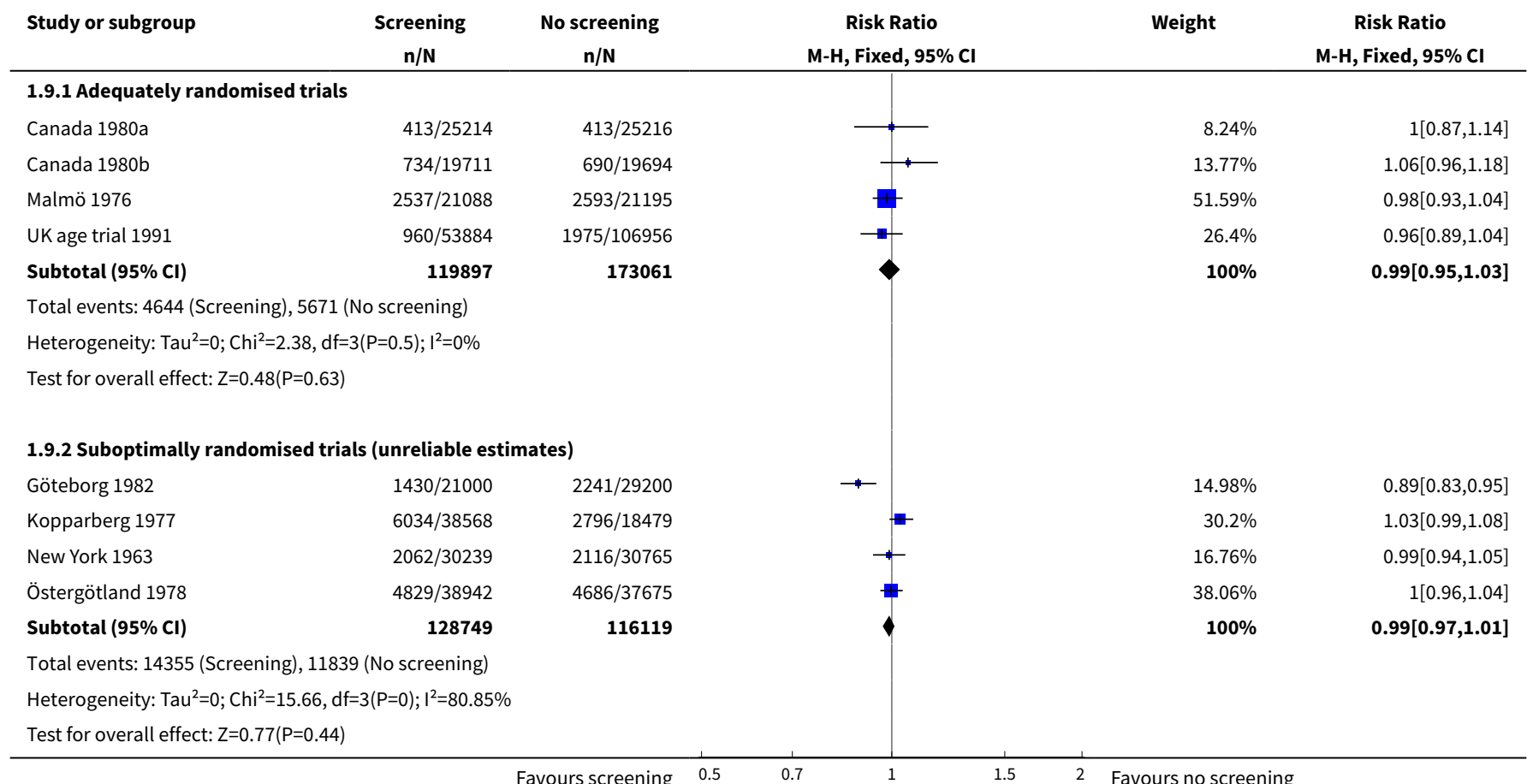

\section{Analysis 1.10. Comparison 1 Screening with mammography versus no screening, Outcome 10 Overall mortality, 7 years follow up, women below 50 years of age.}

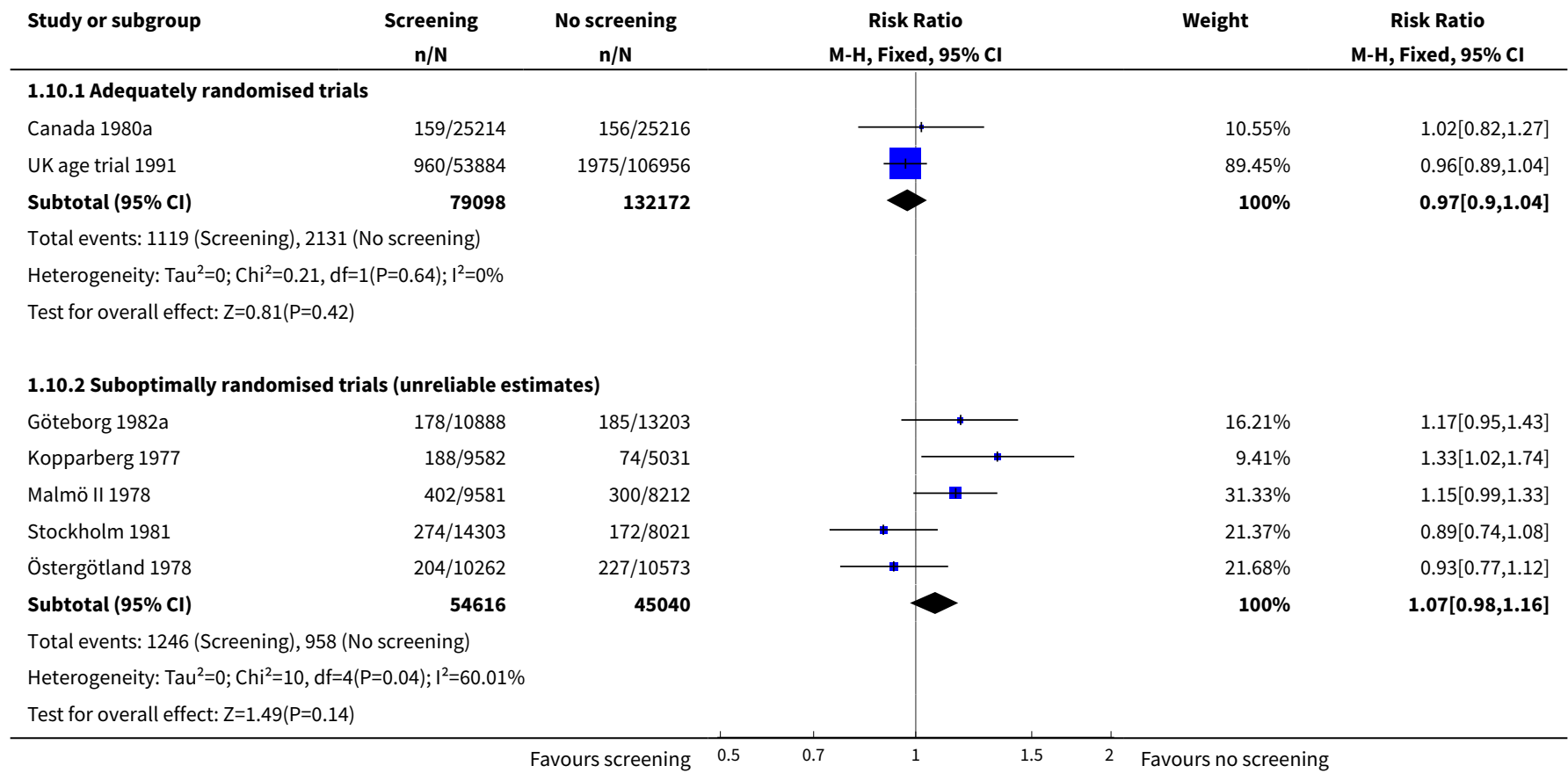


Analysis 1.11. Comparison 1 Screening with mammography versus no screening, Outcome 11 Overall mortality, 7 years follow up, women at least 50 years of age.

\begin{tabular}{|c|c|c|c|c|c|}
\hline Study or subgroup & $\begin{array}{c}\text { Screening } \\
n / N\end{array}$ & $\begin{array}{c}\text { No screening } \\
n / N\end{array}$ & $\begin{array}{c}\text { Risk Ratio } \\
\text { M-H, Fixed, } 95 \% \mathrm{CI}\end{array}$ & Weight & $\begin{array}{c}\text { Risk Ratio } \\
\text { M-H, Fixed, 95\% Cl }\end{array}$ \\
\hline \multicolumn{6}{|c|}{ 1.11.1 Adequately randomised trials } \\
\hline Canada 1980b & $253 / 19711$ & $250 / 19694$ & & $100 \%$ & $1.01[0.85,1.2]$ \\
\hline Subtotal $(95 \% \mathrm{Cl})$ & 19711 & 19694 & & $100 \%$ & $1.01[0.85,1.2]$ \\
\hline \multicolumn{6}{|c|}{ Total events: 253 (Screening), 250 (No screening) } \\
\hline \multicolumn{6}{|c|}{ Heterogeneity: Not applicable } \\
\hline \multicolumn{6}{|c|}{ 1.11.2 Suboptimally randomised trials (unreliable estimates) } \\
\hline Göteborg 1982b & $349 / 10112$ & $591 / 15997$ & $\longrightarrow$ & $6.34 \%$ & $0.93[0.82,1.06]$ \\
\hline Kopparberg 1977 & $3485 / 29007$ & $1619 / 13551$ & & $30.58 \%$ & $1.01[0.95,1.06]$ \\
\hline Stockholm 1981 & $1494 / 24836$ & $864 / 12957$ & $\rightarrow-$ & $15.73 \%$ & $0.9[0.83,0.98]$ \\
\hline Östergötland 1978 & $3385 / 28229$ & $3332 / 26830$ & & $47.34 \%$ & $0.97[0.92,1.01]$ \\
\hline \multicolumn{6}{|c|}{ Total events: 8713 (Screening), 6406 (No screening) } \\
\hline \multicolumn{6}{|c|}{ Heterogeneity: $\mathrm{Tau}^{2}=0 ; \mathrm{Chi}^{2}=5.02, \mathrm{df}=3(\mathrm{P}=0.17) ; \mathrm{I}^{2}=40.26 \%$} \\
\hline Test for overall effect & & & & & \\
\hline
\end{tabular}

Analysis 1.12. Comparison 1 Screening with mammography versus no screening, Outcome 12 Overall mortality, 13 years follow up, women below 50 years of age.

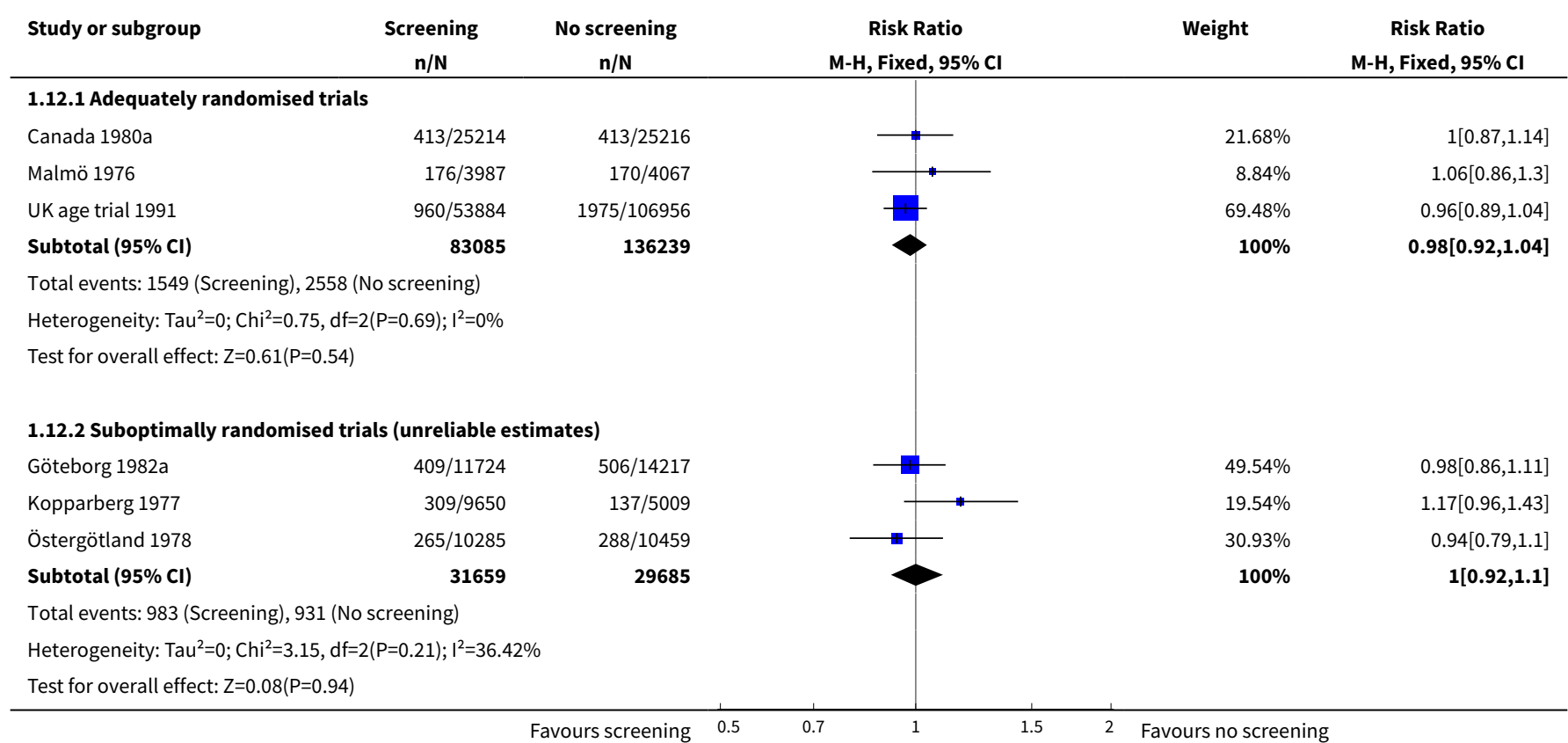


Analysis 1.13. Comparison 1 Screening with mammography versus no screening, Outcome 13 Overall mortality, 13 years follow up, women at least 50 years of age.

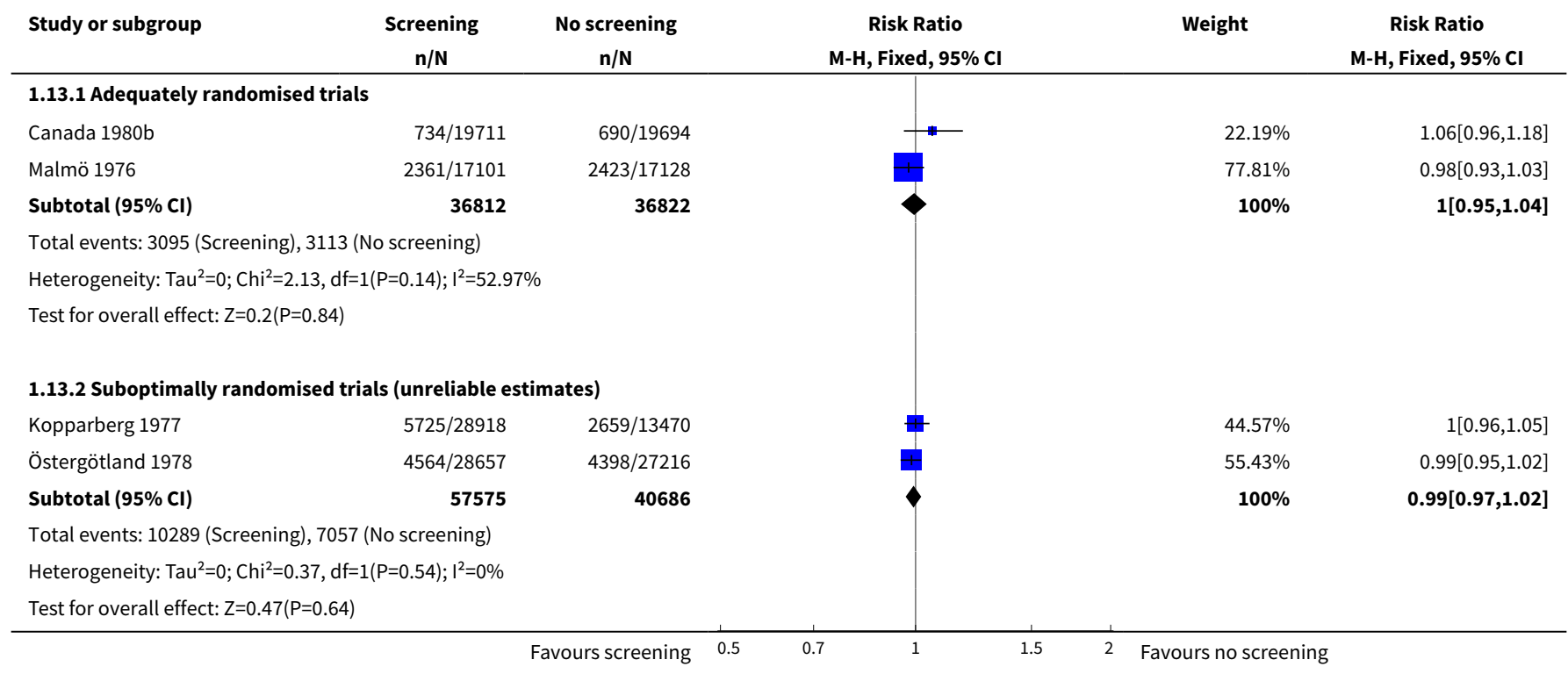

Analysis 1.14. Comparison 1 Screening with mammography versus no screening, Outcome 14 Number of mastectomies and lumpectomies.

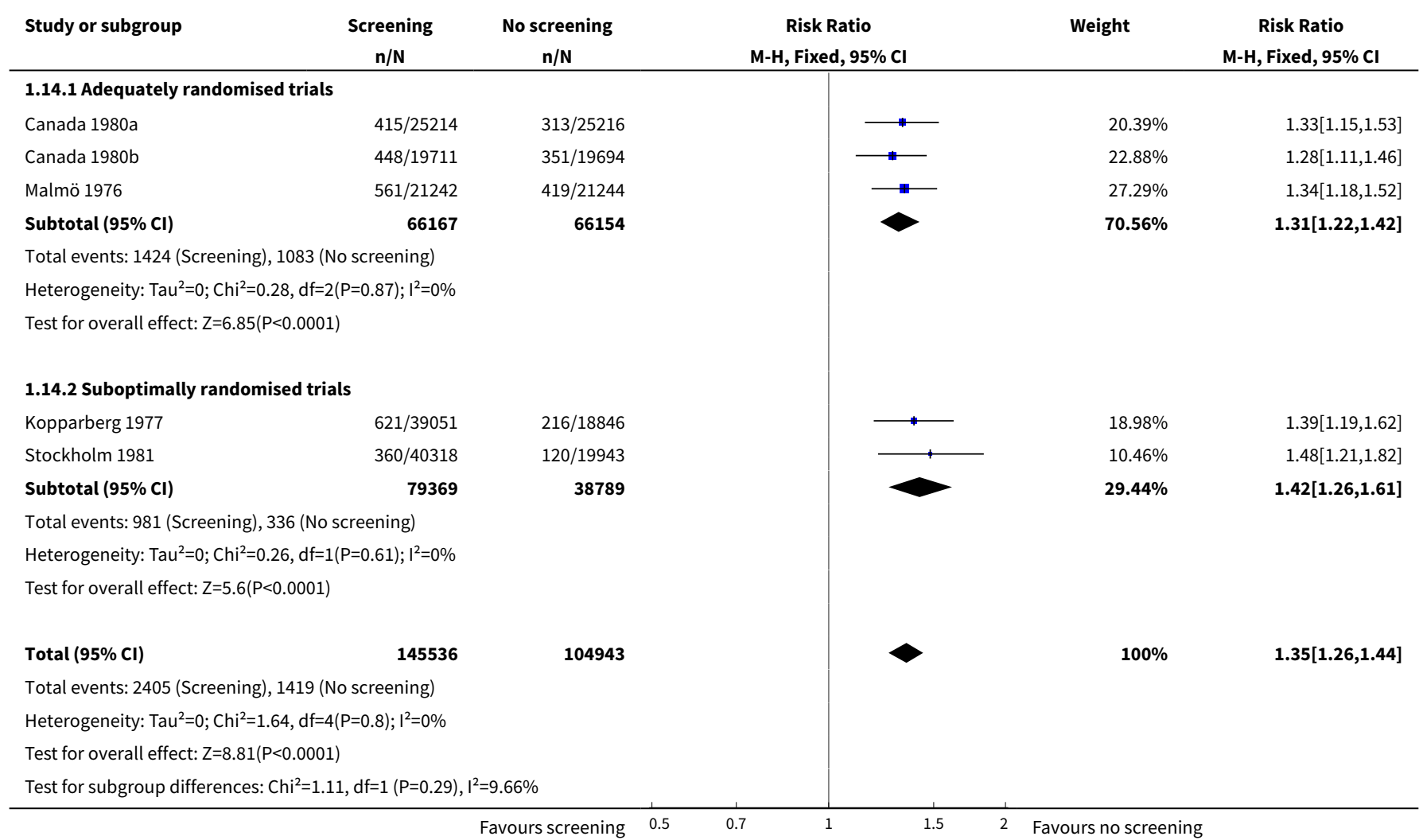




\section{Analysis 1.15. Comparison 1 Screening with mammography} versus no screening, Outcome 15 Number of mastectomies.

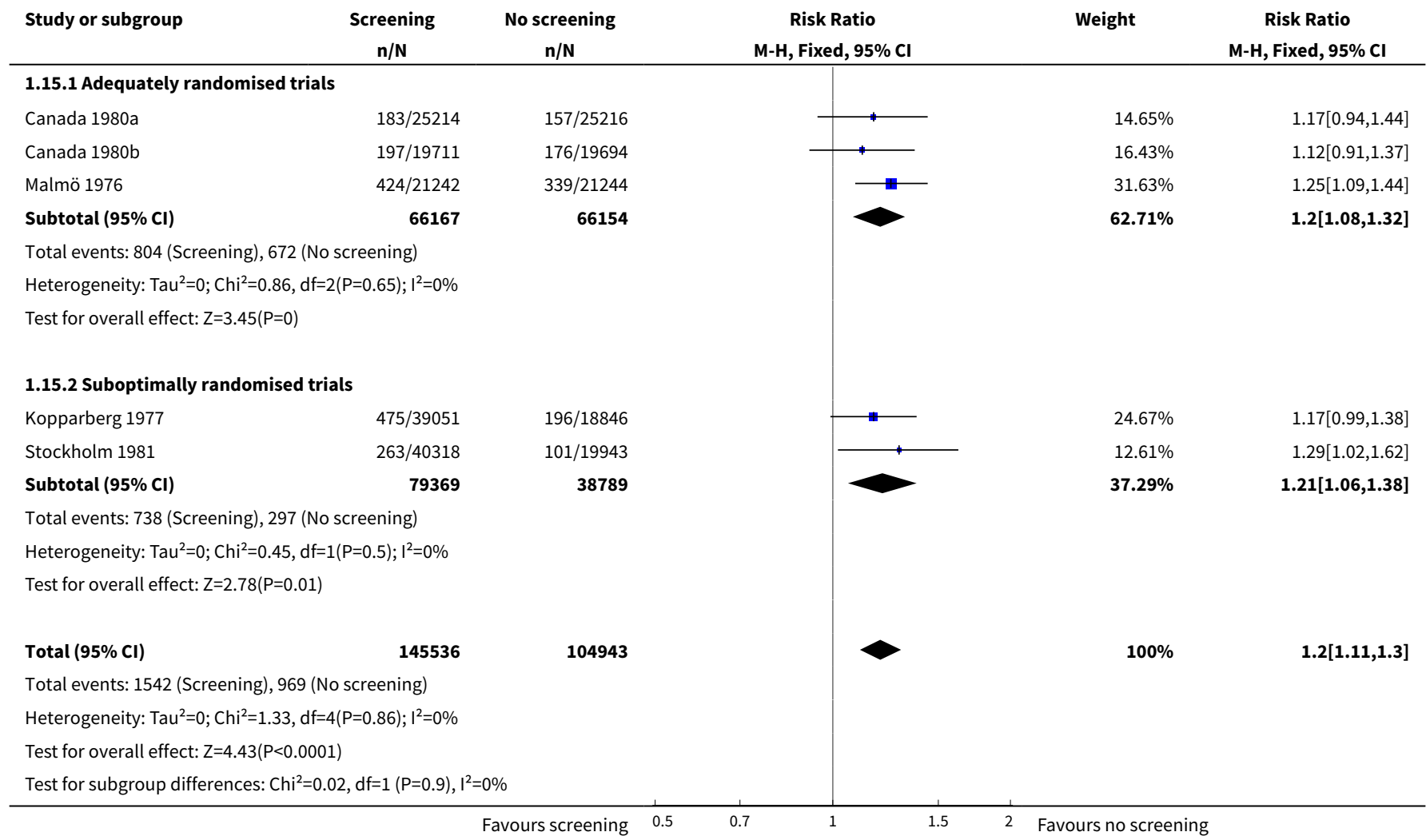

\section{Analysis 1.16. Comparison 1 Screening with mammography versus no screening, Outcome 16 Number treated with radiotherapy.}

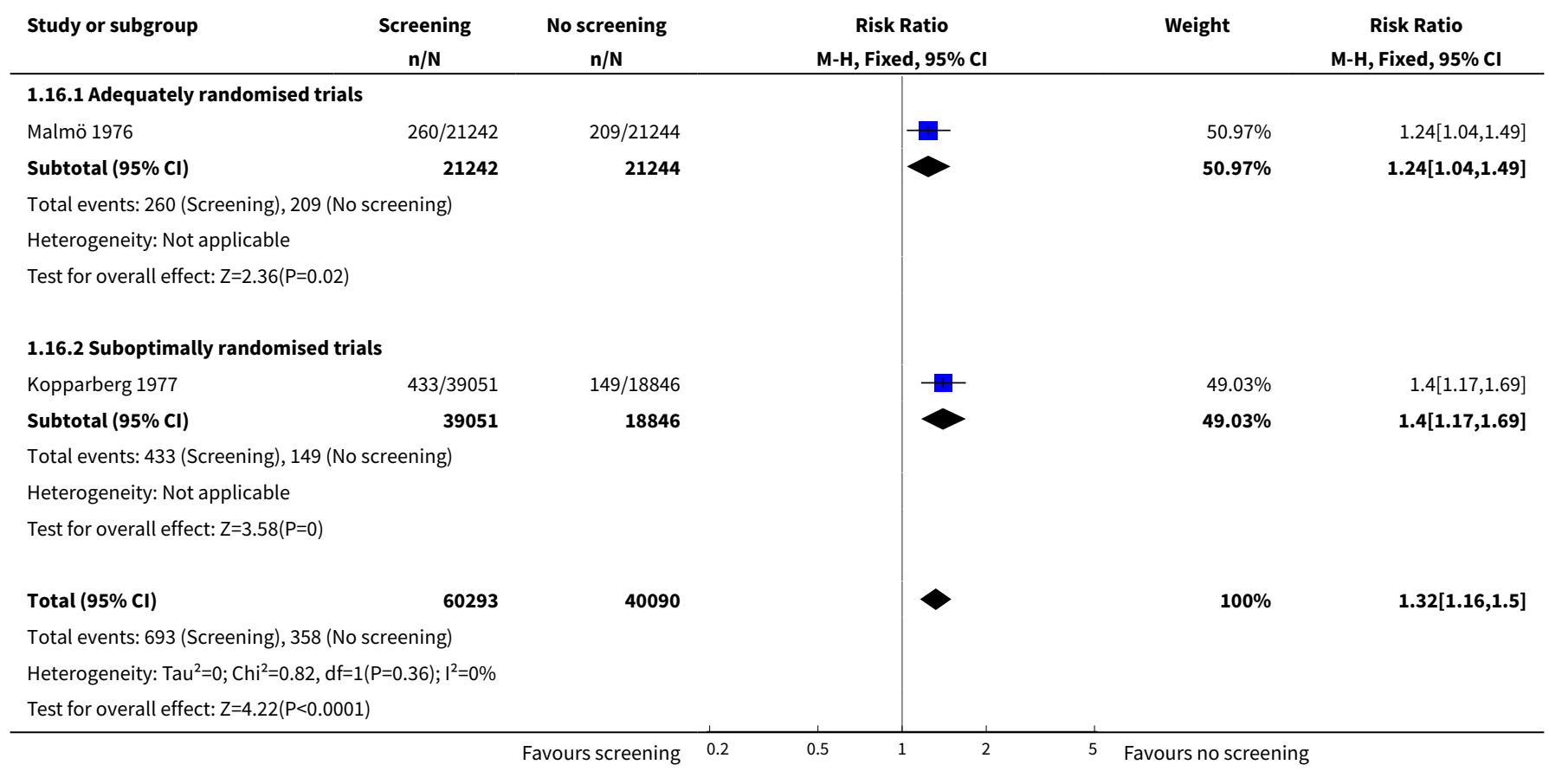




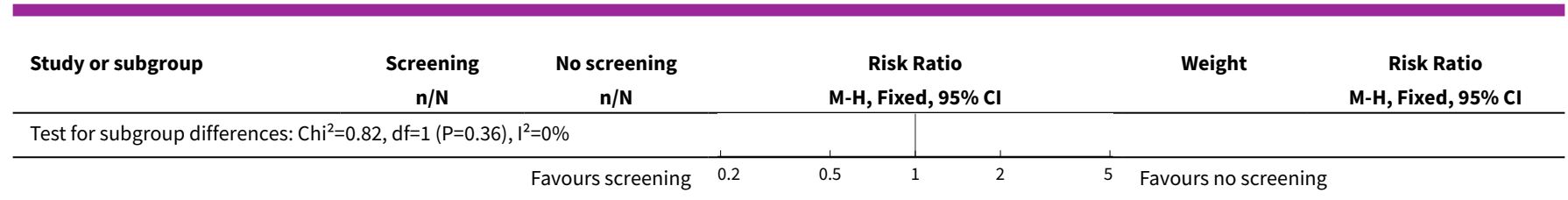

Analysis 1.17. Comparison 1 Screening with mammography versus no screening, Outcome 17 Number treated with chemotherapy.

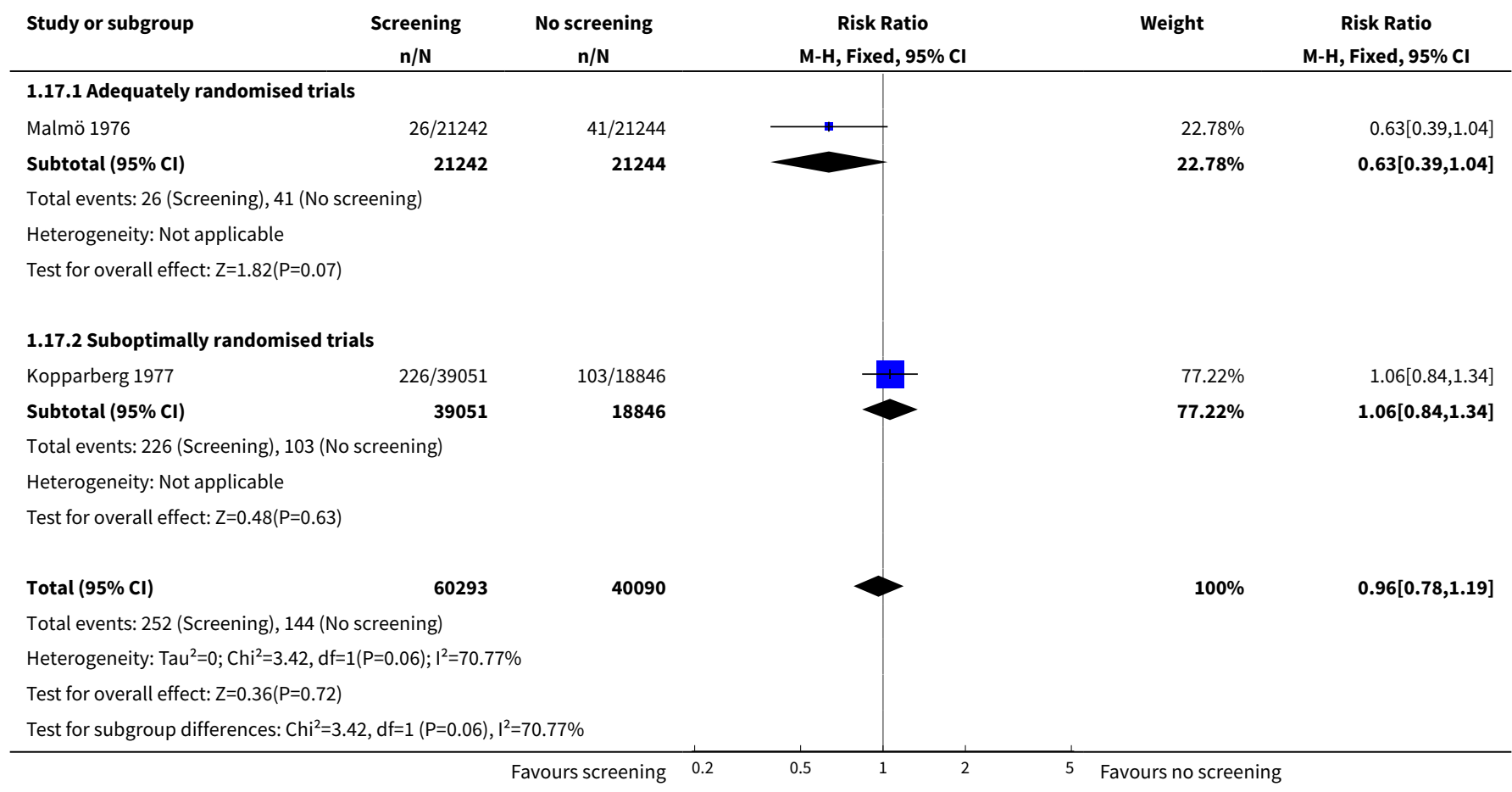

Analysis 1.18. Comparison 1 Screening with mammography versus no screening, Outcome 18 Number treated with hormone therapy.

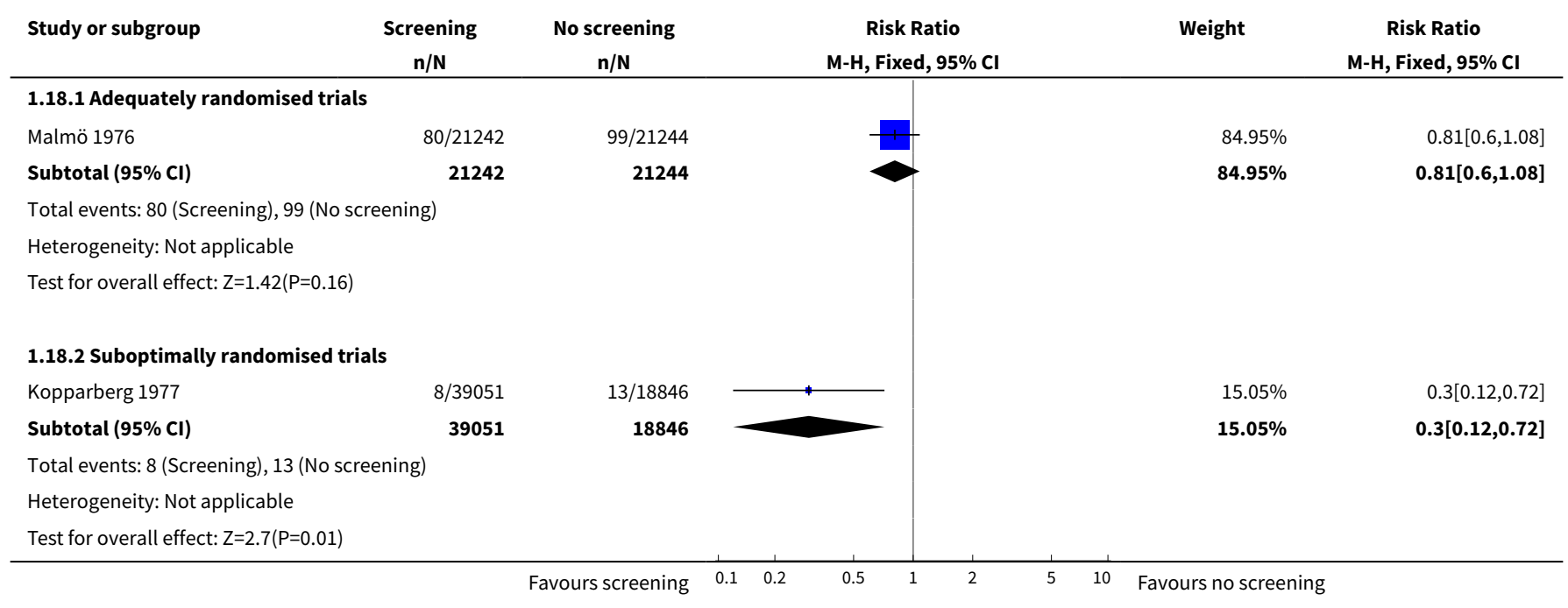




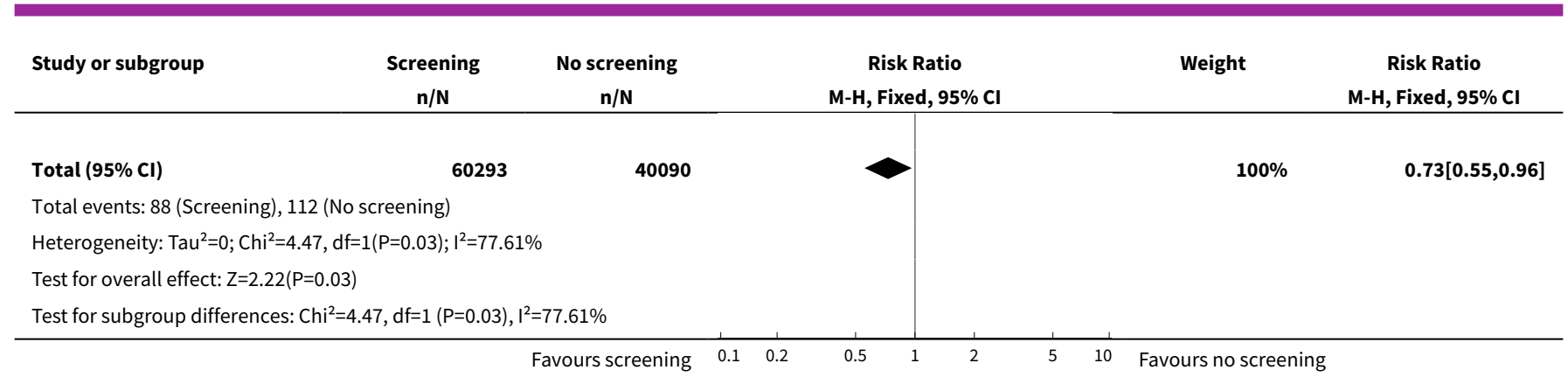

\section{Analysis 1.19. Comparison 1 Screening with mammography versus no screening, Outcome} 19 Mortality among breast cancer patients in the Two-County study, 7 years follow up.

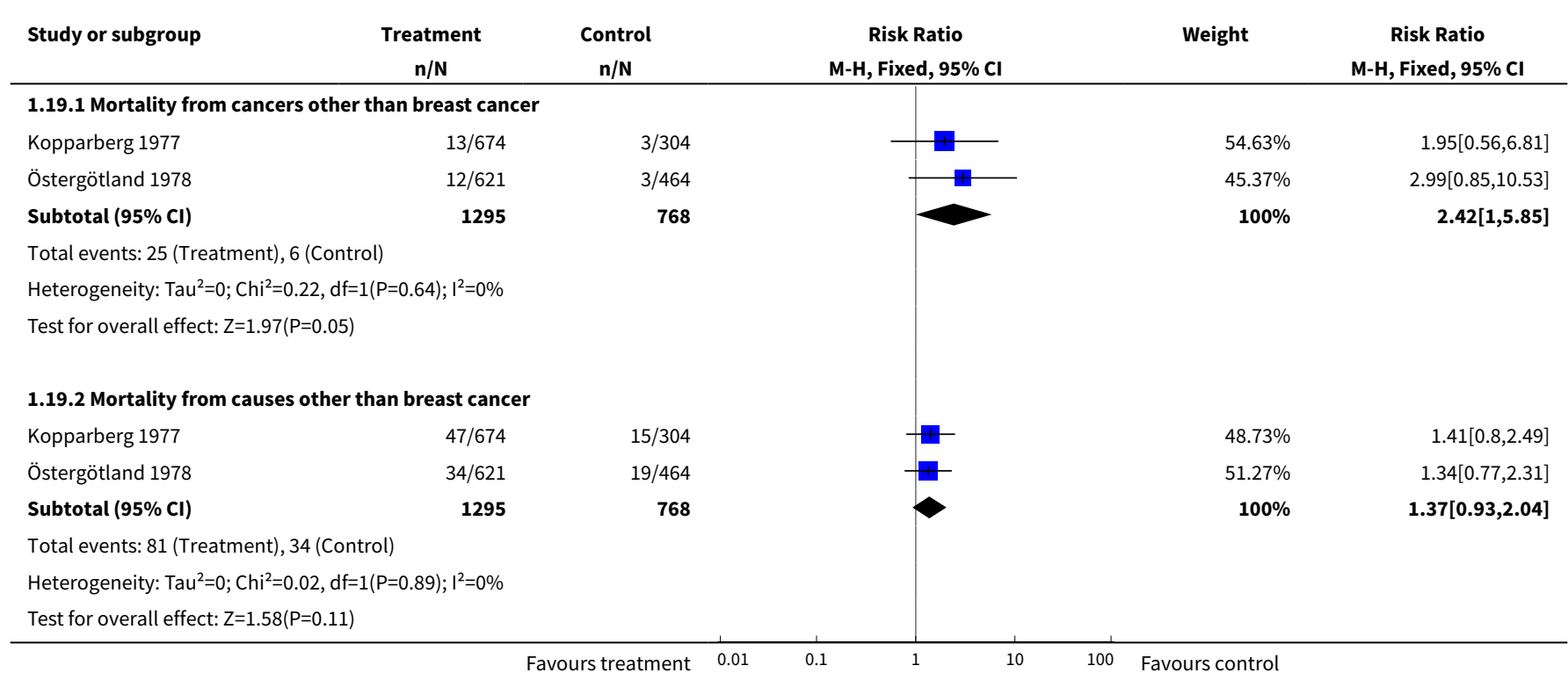

\section{Analysis 1.20. Comparison 1 Screening with mammography versus no screening, Outcome 20 Results for biased trial.}

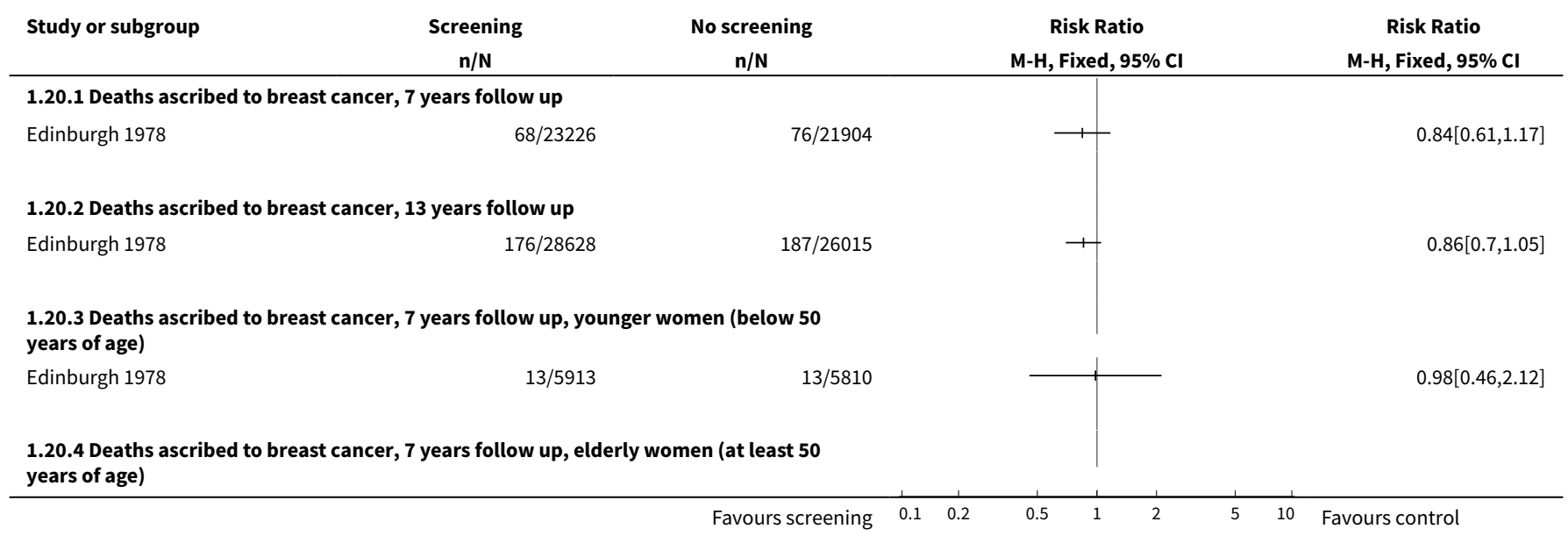




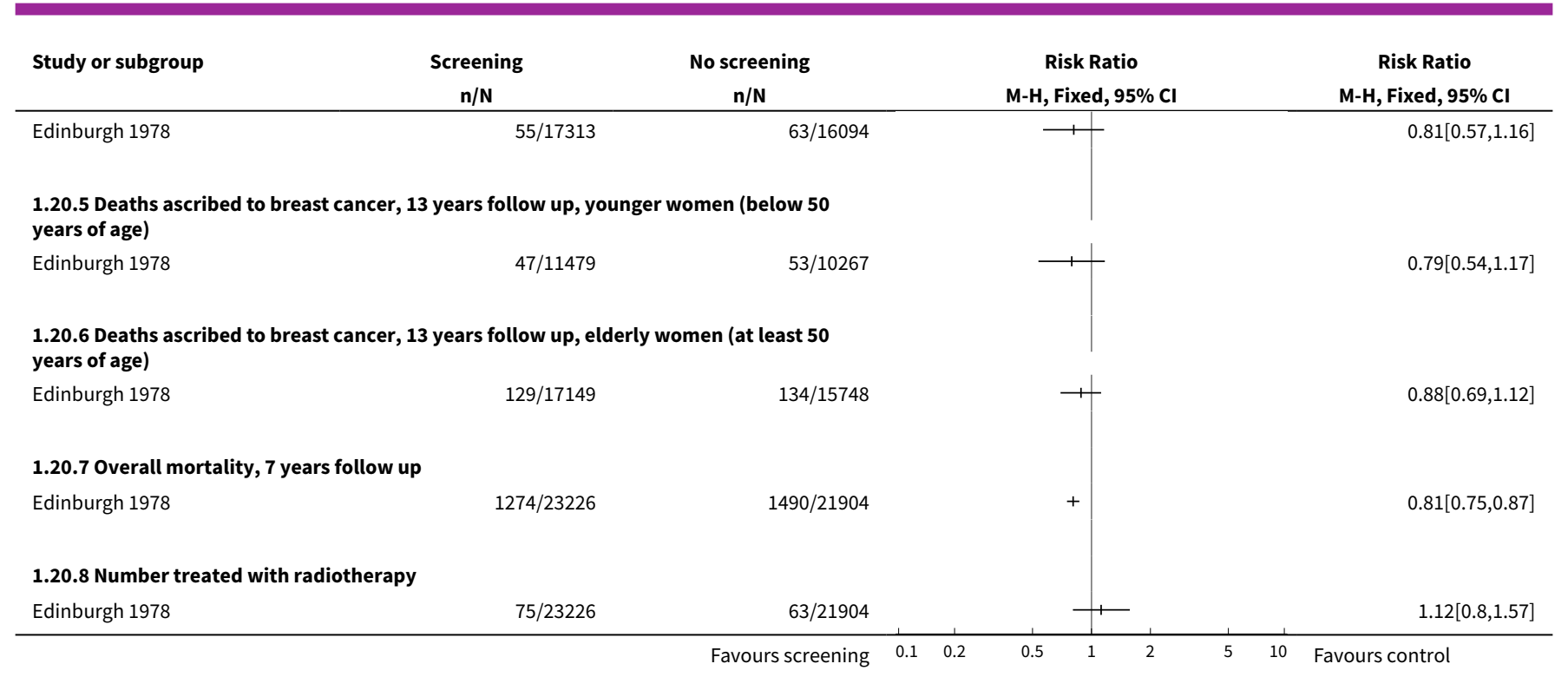

\section{Analysis 1.21. Comparison 1 Screening with mammography versus no screening, Outcome 21 Number of cancers.}

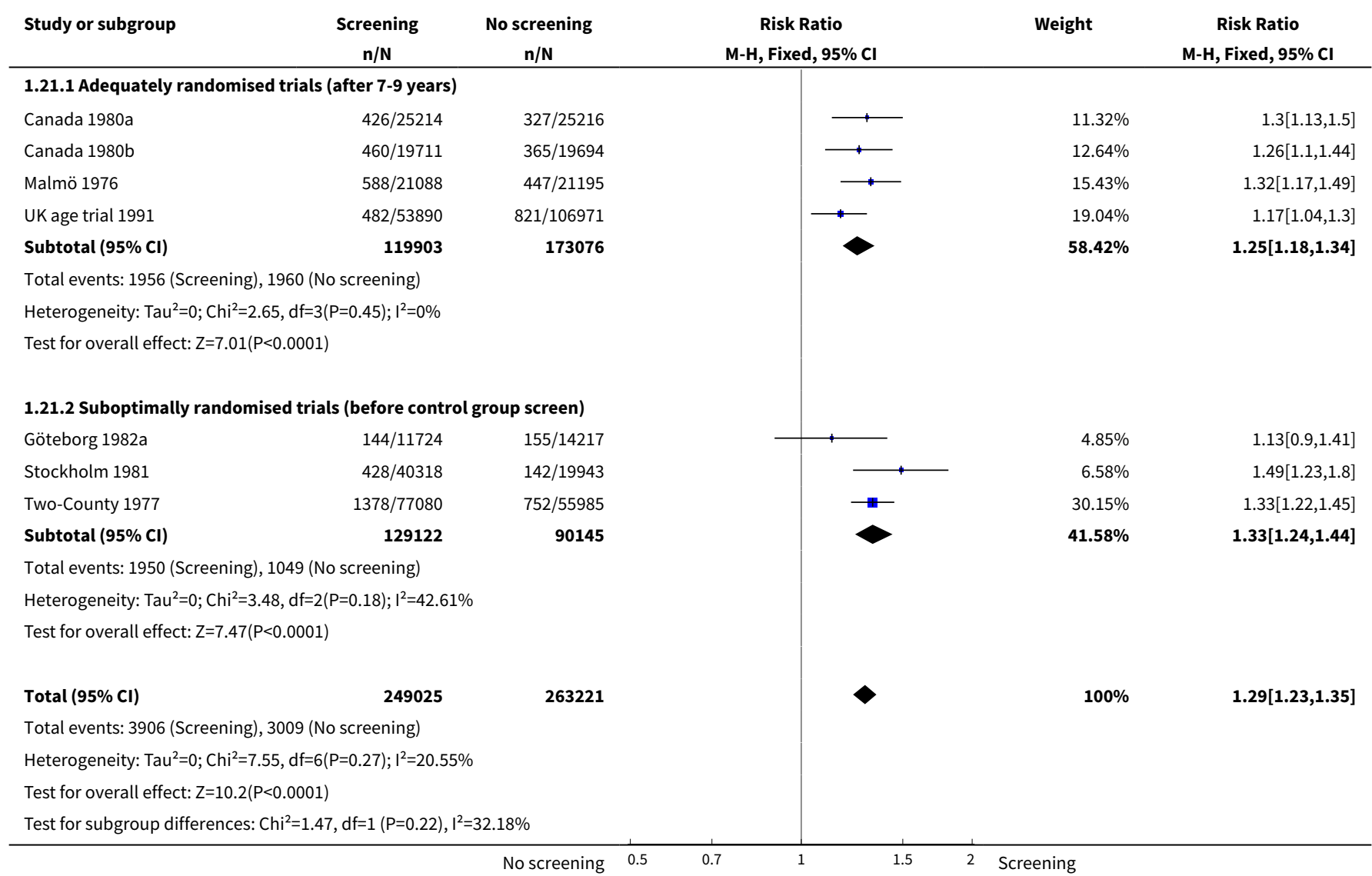

\section{ADDITIONAL TABLES}


Table 1. Examples of varying numbers of women in the Swedish trials

\begin{tabular}{|c|c|c|c|c|}
\hline Study & Age range & Study group & Control group & Reference \\
\hline \multirow[t]{3}{*}{ Malmö } & $40-74$ & 21242 & 21240 & Andersson 1980 \\
\hline & $40-74$ & 21242 & 21244 & Andersson 1983 \\
\hline & $40-74$ & 21088 & 21195 & Andersson 1988 \\
\hline \multirow[t]{12}{*}{ Kopparberg } & total & 47389 & 22658 & Socialstyrelsen 1985 \\
\hline & $40-74$ & 39051 & 18846 & Tabar 1985 \\
\hline & $40-74$ & 38589 & 18582 & Tabar 1989 \\
\hline & $40-74$ & 38562 & 18478 & Nyström 1993 \\
\hline & $40-74$ & 38589 & 18582 & Tabar 1995 \\
\hline & $40-74$ & 38568 & 18479 & Nyström 2000 \\
\hline & $40-74$ & 38588 & 18582 & Nixon 2000 \\
\hline & $40-74$ & data not available & data not available & Nyström 2002 \\
\hline & $40-49$ & 9625 & 5053 & Tabar 1988 \\
\hline & $40-49$ & data not available & data not available & Nyström 1993a \\
\hline & $40-49$ & 9582 & 5031 & Tabar 1995 \\
\hline & $40-49$ & 9650 & 5009 & Nyström 1997 \\
\hline \multirow[t]{12}{*}{ Östergötland } & total & 47001 & 45933 & Socialstyrelsen 1985 \\
\hline & $40-74$ & 39034 & 37936 & Tabar 1985 \\
\hline & $40-74$ & 38491 & 37403 & Tabar 1989 \\
\hline & $40-74$ & 38405 & 37145 & Nyström 1993 \\
\hline & $40-74$ & 38491 & 37403 & Tabar 1995 \\
\hline & $40-74$ & 38942 & 37675 & Nyström 2000 \\
\hline & $40-74$ & 39105 & 37858 & Nixon 2000 \\
\hline & $40-74$ & 38942 & 37675 & Nyström 2002 \\
\hline & $40-49$ & 10312 & 10625 & Tabar 1988 \\
\hline & $40-49$ & data not available & data not available & Nyström 1993a \\
\hline & $40-49$ & 10262 & 10573 & Tabar 1995 \\
\hline & $40-49$ & 10240 & 10411 & Nyström 1997 \\
\hline
\end{tabular}


Table 1. Examples of varying numbers of women in the Swedish trials (Continued)

\begin{tabular}{|c|c|c|c|c|}
\hline Stockholm & $40-64$ & 40318 & 19943 & Frisell 1989a \\
\hline & 40-65 (sic) & 38525 & 20651 & Nyström 1993 \\
\hline & $40-64$ & 40318 & 19943 & Frisell 1997 \\
\hline & $40-69$ & 39139 & 20978 & Nyström 2000 \\
\hline & $40-49$ & data not available & data not available & Nyström 1993a \\
\hline & $40-49$ & 14842 & 7103 & Frisell 1997 \\
\hline & $40-49$ & 14185 & 7985 & Nyström 1997 \\
\hline & $40-49$ & 14303 & 8021 & Nyström 2002 \\
\hline \multirow[t]{6}{*}{ Göteborg } & $40-59$ & 20724 & 28809 & Nyström 1993 \\
\hline & $39-59$ & 21650 & 29961 & Bjurstam 1997a \\
\hline & $40-59$ & 21000 & 29200 & Nyström 2000 \\
\hline & $40-49$ & 10821 & 13101 & Nyström 1993a \\
\hline & $39-49$ & 11724 & 14217 & Bjurstam 1997 \\
\hline & $40-49$ & 10888 & 13203 & Nyström 2002 \\
\hline
\end{tabular}

WHAT'S NEW

\begin{tabular}{lll}
\hline Date & Event & Description \\
\hline 17 June 2013 & Review declared as stable & $\begin{array}{l}\text { This review update did not identify any new randomised con- } \\
\text { trolled trials on screening mammography. As it is now thought } \\
\text { to be unlikely that clinical trials will be conducted, we do not ex- } \\
\text { pect to update this review }\end{array}$ \\
& \\
\hline
\end{tabular}

\section{H I S T O R Y}

Protocol first published: Issue 1, 2000

Review first published: Issue 4, 2001

\begin{tabular}{lll}
\hline Date & Event & Description \\
\hline 22 November 2012 & $\begin{array}{l}\text { New citation required but conclusions } \\
\text { have not changed }\end{array}$ & $\begin{array}{l}\text { This review update includes an accumulation of changes in the } \\
\text { discussion section }\end{array}$ \\
\hline 22 November 2012 & New search has been performed & $\begin{array}{l}\text { Performed search for new studies on 22 November 2012. No new } \\
\text { studies included }\end{array}$ \\
\hline 17 November 2010 & Amended & Corrected labels for Figure 1.21. \\
\hline \hline
\end{tabular}

Screening for breast cancer with mammography (Review) 


\begin{tabular}{lll}
\hline Date & Event & Description \\
\hline 5 August 2009 & $\begin{array}{l}\text { New citation required but conclusions } \\
\text { have not changed }\end{array}$ & new citation = no change to conclusions \\
\hline 3 March 2009 & New search has been performed & Data from a new trial, UK age trial, added. \\
\hline 12 July 2006 & $\begin{array}{l}\text { New citation required and conclusions } \\
\text { have changed }\end{array}$ & Substantive amendment \\
\hline
\end{tabular}

\section{CONTRIBUTIONS OF AUTHORS}

PCG wrote the draft protocol and did the searches. Two authors extracted the main data independently and contributed to the review. PCG is guarantor.

\section{DECLARATIONS OF INTEREST}

None. We had no a priori opinion on the effect of screening for breast cancer when we were asked by the Danish National Board of Health in 1999 to review the randomised trials.

\section{SOURCES OF SUPPORT}

\section{Internal sources}

- Rigshospitalet, Denmark.

\section{External sources}

- Danish Institute for Health Technology Assessment, Denmark.

\section{DIFFERENCES BETWEEN PROTOCOLANDREVIEW}

A new outcome was added when we discovered that breast cancer mortality is an unreliable outcome. This was mortality from any cancer.

\section{INDEX TERMS}

\section{Medical Subject Headings (MeSH)}

*Mass Screening; Breast Neoplasms [ ${ }^{\star}$ diagnostic imaging] [ ${ }^{*}$ mortality] [surgery]; Cause of Death; Diagnostic Errors; Mammography [ ${ }^{*}$ adverse effects] [ ${ }^{*}$ psychology]; Mastectomy [statistics \& numerical data]; Pamphlets; Patient Education as Topic; Randomized Controlled Trials as Topic

\section{MeSH check words}

Adult; Aged; Female; Humans; Middle Aged 